\title{
ZOOTAXA
}

2371

\section{A review of the Australian millipede genus Atelomastix (Diplopoda: Spirostreptida: Iulomorphidae)}

\author{
KAREN L. EDWARD ${ }^{1,2}$ \& MARK S. HARVEY ${ }^{2,1,3}$ \\ ${ }^{1}$ School of Animal Biology, University of Western Australia, Crawley, Western Australia 6009, Australia. \\ Email:edwark02@student.uwa.edu.au
}

${ }^{2}$ Department of Terrestrial Zoology, Western Australian Museum, Locked Bag 49, Welshpool DC, Western Australia 6986, Australia. Email: mark.harvey@museum.wa.gov.au

${ }^{3}$ Research Associate, Division of Invertebrate Zoology, American Museum of Natural History, New York; Research Associate,

California Academy of Sciences, San Francisco

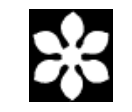

Magnolia Press

Auckland, New Zealand 
KAREN L. EDWARD \& MARK S. HARVEY

A review of the Australian millipede genus Atelomastix (Diplopoda: Spirostreptida: Iulomorphidae)

(Zootaxa 2371)

63 pp.; $30 \mathrm{~cm}$.

25 February 2010

ISBN 978-1-86977-483-7 (paperback)

ISBN 978-1-86977-484-4 (Online edition)

\section{FIRST PUBLISHED IN 2010 BY}

Magnolia Press

P.O. Box 41-383

Auckland 1346

New Zealand

e-mail: zootaxa@mapress.com

http://www.mapress.com/zootaxa/

(C) 2010 Magnolia Press

All rights reserved.

No part of this publication may be reproduced, stored, transmitted or disseminated, in any form, or by any means, without prior written permission from the publisher, to whom all requests to reproduce copyright material should be directed in writing.

This authorization does not extend to any other kind of copying, by any means, in any form, and for any purpose other than private research use.

ISSN 1175-5326 (Print edition)

ISSN 1175-5334 (Online edition) 


\title{
Table of contents
}

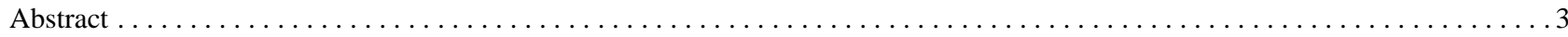

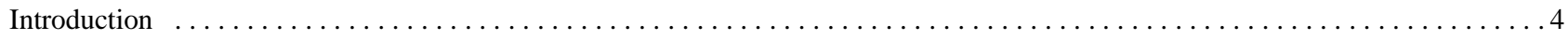

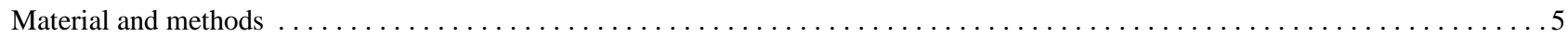

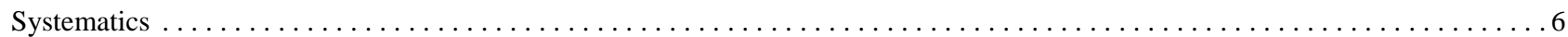

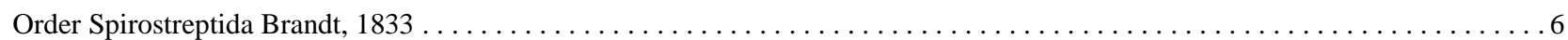

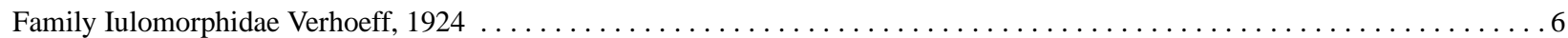

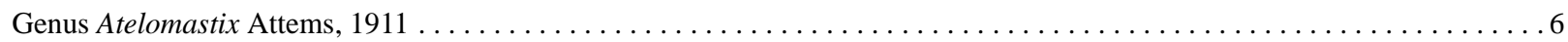

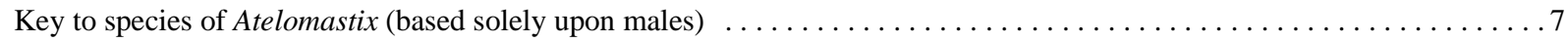

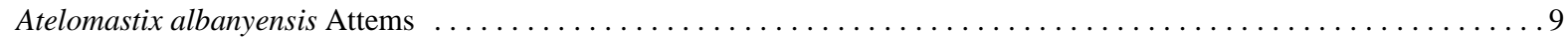

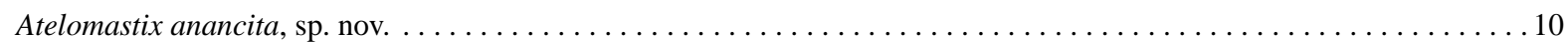

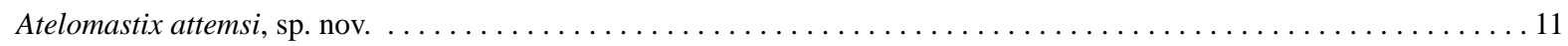

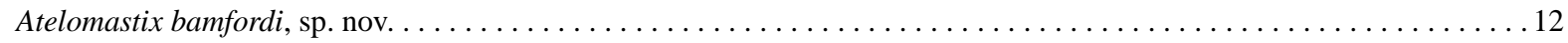

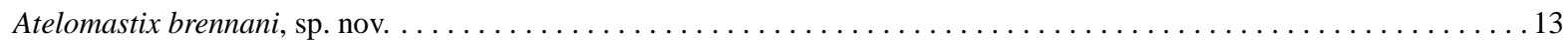

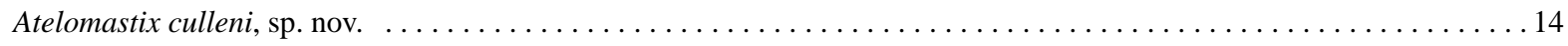

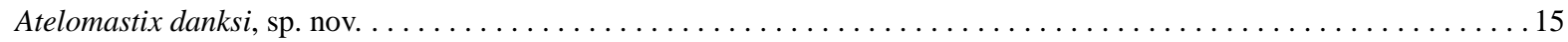

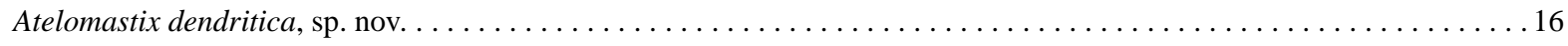

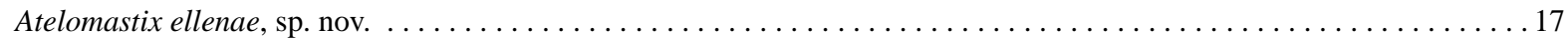

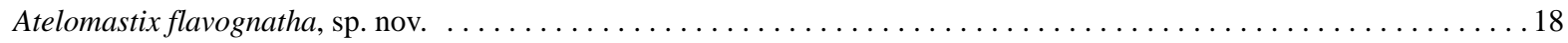

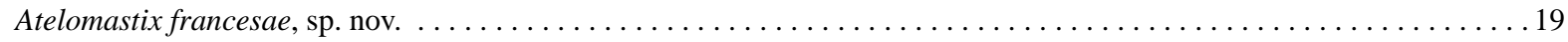

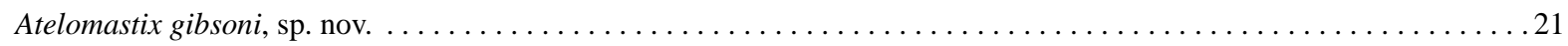

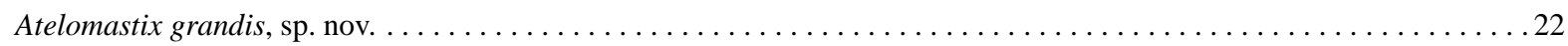

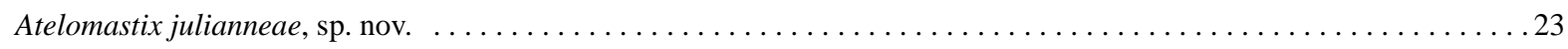

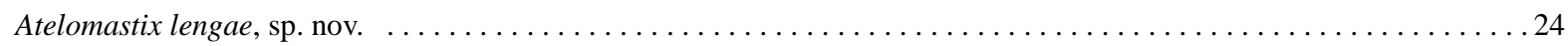

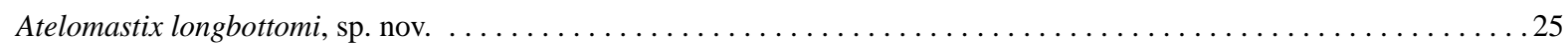

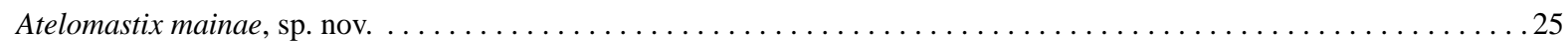

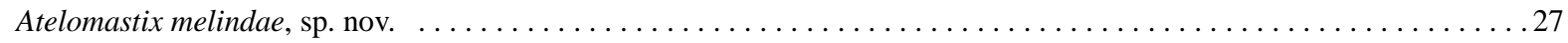

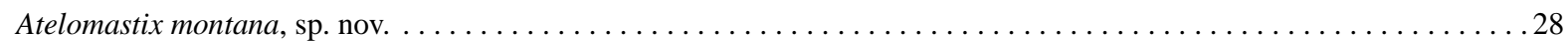

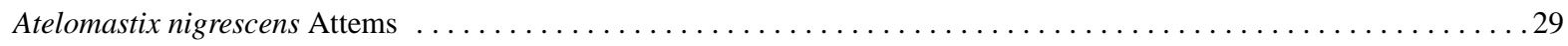

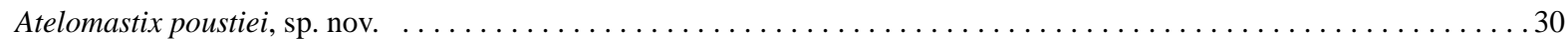

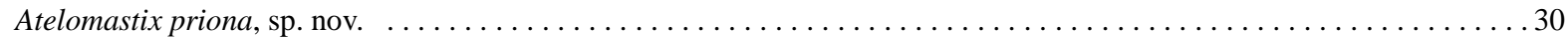

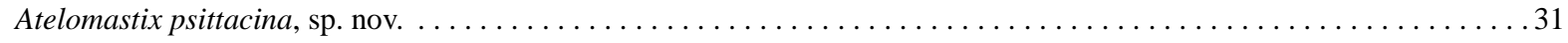

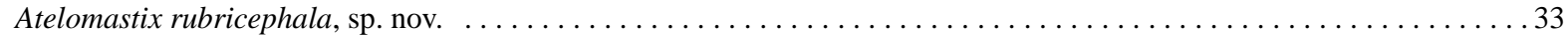

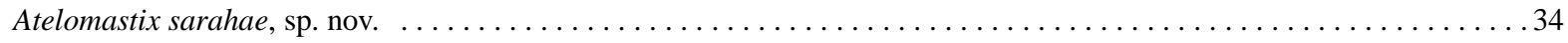

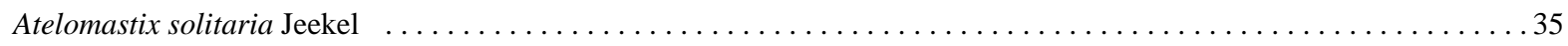

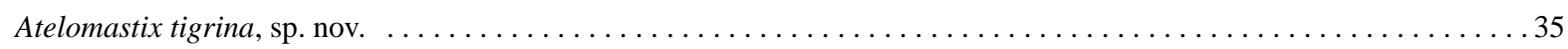

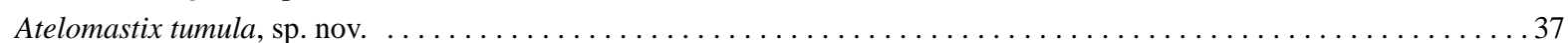

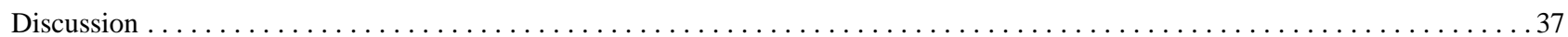

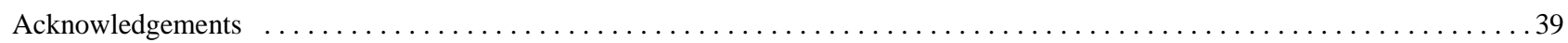

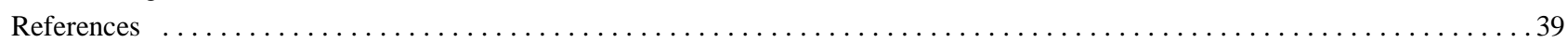

\begin{abstract}
A review of the Australian endemic millipede genus Atelomastix reveals the presence of 28 species, including the type species A. albanyensis Attems, A. nigrescens Attems, and 25 new species from Western Australia, as well as A. solitaria Jeekel from Victoria. All species are from the high rainfall zone of southern Australia. The new species are: $A$. anancita, A. attemsi, A. bamfordi, A. brennani, A. culleni, A. danksi, A. dendritica, A. ellenae, A. flavognatha, A. francesae, A. gibsoni, A. grandis, A. julianneae, A. lengae, A. longbottomi, A. mainae, A. melindae, A. montana, A. poustiei, A. priona, A. psittacina, A. rubricephala, A. sarahae, A. tigrina and A. tumula. Most species are shown to have extremely small distributions and all are classified as short-range endemic species. Most species have been collected at very few locations, occurring in discontinuous habitats such as mountain ranges, islands, granite outcrops, or fragments of wet forest.
\end{abstract}

Key words: taxonomy, new species, morphology, Western Australia, Victoria 


\section{Introduction}

The southwestern corner of Western Australia is known to be a region of immense biological and biogeographical interest. It is regarded as a major global biodiversity hotspot (Myers et al. 2000), renowned for its assemblage of Gondwanan relicts (Main 1999) and high levels of endemism in both flora and fauna (Hopper 1979; Hopper \& Gioia 2004; Hopper, et al. 1996). Historical events are thought to have shaped the diversity and influenced speciation within the region. Although Western Australia has been subject to major tectonic movements with the fragmentation of Gondwana, marine intrusions, and fluctuating climatic conditions, the combination of an ancient unglaciated landscape, large areas above sea level for more than 200 million years, and the lack of significant mountain building, have provided unparalleled opportunities for the persistence of relict terrestrial taxa (Hopper 1979; Hopper \& Gioia 2004; Hopper, et al. 1996). The region offers a unique area in which to test historical biogeographical hypotheses (Edwards, et al. 2007).

Changing sea levels in the past may have influenced a number of speciation events within southwestern Australia. A series of significant marine intrusions onto the Australian continent occurred during the Eocene and Oligocene (Haq, et al., 1987), producing a mosaic of numerous islands and peninsulas that were positioned along the current southwest coastline, similar to the present-day oceanic archipelagos (Hopper 1979). Peaks of the Stirling Range, Porongurup Range, and other granite monadnocks along the coast, such as Torbay would have been islands during this period, resulting in the fragmentation and isolation of a number of taxa (Main 1999). In particular, this event is suggested to have led to speciation of flora in the southwest (Hopper 1979). However, several studies have suggested that the Eocene period was too remote to account for the evolution of certain fauna, such as onychophorans (Reid 2002) and millipedes (Edward 2003), but instead favour post-Eocene events, such as the onset of aridity during the Miocene. Widespread aridification of Australia would have resulted in the fragmentation of habitats and thus populations dependent on forests and refugial ecosystems (Byrne, et al. 2008; Harvey 2002). Although much information is available about speciation and biogeographical patterns of some plants and vertebrate animals in southwestern Australia, our understanding of the processes generating diversity in other groups is poor. Recent research on frog species within southwestern Australia have indicated within-species population divergence during the late Tertiary (Edwards 2007; Edwards, et al. 2008).

The millipede class Diplopoda is a highly diverse group of terrestrial organisms, with over 12,000 described species and an estimated 80,000 species yet to be described (Hoffman 1990; Kime \& Golovatch 2000; Shelley 2007; Sierwald \& Bond 2007). Further, examination of the fossil record shows that the earliest known millipedes date back to the Paleozoic over 400 million years ago (e.g. Edgecombe 1998; Kime \& Golovatch 2000; Wilson and Anderson 2004). Although they play an important ecological role as detritovores, little is known about their true diversity, morphology, ecology and phylogeny (Sierwald \& Bond 2007). Within Western Australia alone there are estimated to be approximately 1,000 species of myriapods, about $75 \%$ of which are endemic to Western Australia (Hopper, et al. 1996). Very few symphylans and pauropods have been recorded from Western Australia (e.g. Attems 1911; Scheller 1961), and a few dozen centipedes are known (e.g. Attems 1911; Edgecombe \& Barrow 2007; Edgecombe 2005; Jones 1998; Koch 1982, 1983a, 1983b, 1985a, 1985b). The bulk of myriapod diversity lies within the Diplopoda where numerous new species have been collected primarily within the higher rainfall zone in southwestern Australia (e.g. Moir, et al. 2009). Of the taxa found in this high rainfall zone, members of the spirostreptid family Iulomorphidae dominate.

The composition of the Iulomorphidae is unresolved, but 14 genera are currently included (e.g. Jeekel 2006; Korsós \& Johns 2009; Mauriès 1987): Amastigogonus Brölemann, Apocoptogonus Jeekel, Atelomastix Attems, Dimerogonus Attems, Dinocambala Attems, Merioproscelum Verhoeff, Podykipus Attems, Proscelomerion Verhoeff, Samichus Attems, Thaumaceratopus Verhoeff and Victoriocambala Verhoeff from Australia; Eumastigonus Chamberlin from New Zealand; and Iulomorpha Porat and Stenjulomorpha Schubart from South Africa. 
The presence of iulomorphids in Australia, New Zealand and South Africa points to a strong Gondwanan lineage, and the Australian fauna is further differentiated with Amastigogonus, Apocoptogonus, Dimerogonus, Merioproscelum, Proscelomerion, Thaumaceratopus and Victoriocambala restricted to eastern Australia (e.g. Brölemann 1913; Hoffman 1980; Jeekel 2006; Verhoeff 1924), and Dinocambala, Podykipus and Samichus restricted to southwestern Australia (Attems 1911; Brölemann 1913; Hoffman 1980; Verhoeff 1924). The only genus that is known to be found on both sides of the continent is Atelomastix which occurs in southwestern Australia and Victoria (Attems 1911; Jeekel 2009). The four Western Australian genera, Atelomastix, Dinocambala, Podykipus and Samichus, all described by Attems (1911) based upon material collected during the 1905 Hamburg Southwest Australian Research Expedition by W. Michaelsen and R. Hartmeyer, are accompanied by several apparently undescribed genera of indeterminate affinities that have been collected from various localities. Although very few Western Australian iulomorphid species have been named, we are aware of numerous new species in the genera Atelomastix, Podykipus and Samichus (lodged in the Western Australian Museum), many of which formed the basis for the biogeographic analysis on species turnover in southwestern Australian millipedes (Moir, et al. 2009). In contrast, Dinocambala is represented in the collections of the Western Australian Museum by only a single species, $D$. ingens Attems, which occurs in a narrow north-south latitudinal band on the Darling Range from Millendon ( $\left.31^{\circ} 48^{\prime} \mathrm{S}, 116^{\circ} 04^{\prime} \mathrm{E}\right)$ to Serpentine National Park (32 $22^{\prime}$ S, $\left.116^{\circ} 00^{\prime} \mathrm{E}\right)$ (M. Harvey, unpublished data). Species of Podykipus extend from Warren National Park (34⒉'S, $115^{\circ} 58^{\prime} \mathrm{E}$ ) in the south to Shark Bay (ca. $26^{\circ} 30^{\prime} \mathrm{S}, 114^{\circ} 00^{\prime} \mathrm{E}$ ) in the north, usually within $50 \mathrm{~km}$ of the west coast. Samichus occurs along the south coast from Mount Chudalup (34 ${ }^{\circ} 46^{\prime} \mathrm{S}$,

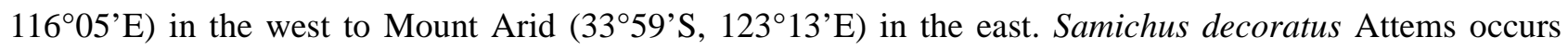
from Mount Frankland National Park ( $34^{\circ} 49^{\prime}$ S, $\left.116^{\circ} 43^{\prime} \mathrm{E}\right)$ to Torndirrup National Park ( $\left.35^{\circ} 06^{\prime} \mathrm{S}, 117^{\circ} 58^{\prime} \mathrm{E}\right)$, with at least another nine unnamed species, including three endemic to the Stirling Range National Park, one in Cape Arid National Park, one in Le Grand National Park and Duke of Orleans Bay, one near Bremer Bay, two in Two Peoples Bay Nature Reserve and one in Waychinicup National Park and Mount Manypeaks Nature Reserve (Framenau, et al. 2008).

Atelomastix, the subject of the present study, is widespread through southwestern Western Australia and western Victoria, and is thought to be extremely diverse with interesting fine-scale biogeographical patterns (Edward 2003). However, until now, only three species, Atelomastix albanyensis Attems, A. nigrescens Attems and A. solitaria Jeekel have been described (Attems 1911; Jeekel 2009; Mesibov 2009). Atelomastix millipedes may prove to be good indicators for biogeographical analysis (Moir, et al. 2009). Like many other native millipedes, they have a low tendency for dispersal, are restricted to moist habitats, are susceptible to desiccation, and inhabit increasingly fragmented environments (Harvey 2002; Mesibov 1994, 2003c; Mesibov, et al. 2002; Moir, et al. 2009). Further, these millipedes exist as relictual taxa in southwestern Australia and, due to their Gondwanan associations, may have experienced a number of historical events that could have potentially isolated populations and influenced speciation. In this paper we aim to document and describe the incredible diversity of Atelomastix species occurring with southwestern Australia. This study is the first comprehensive taxonomic revision of an Australian spirostreptid millipede genus.

\section{Material and methods}

The vast majority of the material examined in this study is lodged in the Western Australian Museum, Perth (WAM), with the type specimens described by Attems (1911) lodged in Museum für Naturkunde, Institut für Systematische Zoologie, Berlin, Germany (ZMB) and Zoologisches Institut und Zoologisches Museum, Hamburg, Germany (ZMH). The specimens of Atelomastix solitaria recently described from Victoria (Jeekel 2009) are lodged in the South Australian Museum, Adelaide (SAMA), but were not available for this study. 
Specimens were examined in $75 \%$ ethanol, and anterior gonopods dissected from adult males. Muscle tissue was discarded and the right gonopod from each pair was mounted interno-lateral side up onto temporary glass slides in Hoyer's solution (Krantz 1978; Krantz \& Walter 2009) or 25\% lactic acid at room temperature with $10 \mathrm{~mm}$ coverslips supported by small sections of 0.25 or $0.35 \mathrm{~mm}$ diameter nylon fishing line. After the study specimens were washed in distilled water and returned to $75 \%$ ethanol with the dissected portions placed in $12 \times 3 \mathrm{~mm}$ glass genitalia microvials (BioQuip Products, Inc.). All specimens were studied using an Olympus BH-2 compound microscope and illustrated with the aid of a drawing tube. Measurements were taken at the highest possible magnification using an ocular graticule. Millipede width was measured at the collum, behind the head. Number of trunk segments include the collum and preanal segment, and leg pair number includes the first pair which are terminally rounded without a distal claw. Photographs of individuals were taken with a Leica MZ16 digital imaging system. The maps were produced with the computer program ArcMap 9.1 (ESRI Inc.) after the relevant locality data were stored in an Access database. Coordinates were obtained in situ at the time of collection using a global positioning system (GPS) unit. Terminology for morphological features follows Attems (1911) as modified by Jeekel (1985). The etymologies for many of the new species were derived from Brown (1956). The species are treated in alphabetical order.

\section{Systematics \\ Order Spirostreptida Brandt, 1833 \\ Family Iulomorphidae Verhoeff, 1924 \\ Genus Atelomastix Attems, 1911}

Atelomastix Attems 1911: 192; Jeekel 1971: 107; Hoffman 1980: 91.

Type species: Atelomastix albanyensis Attems, 1911, by subsequent designation of Jeekel (1971).

Diagnosis: Males of the genus Atelomastix differ from other iulomorphid genera by the morphology of the male anterior gonopods which are laterally compressed, terminally split into three sclerites and possess a pseudoflagellum with a chitinous duct that originates from sclerite $a$ of the telopodite and emerges towards distal end. Males of this genus are also distinguished by the broadened femur, rounded tarsi and lack of distal claws of the first pair of legs.

Description: Size: adult length 11-48 cm, maximum mid-body diameter between 1.0-2.9 mm, number of podous rings: $36-64$, with $2-4$ apodous.

Colour: variable from dark brown, blue green to black. Some with distinctive colour pattern such as dark brown with bright yellow bands or grey brown with red head and collum.

Head (see Figs. 10, 23, 25, 26, 34, 35, 119): gnathochilarium epinannolenidean type (Figs. 25, 26, 119), 3-5 teeth on labium; mandible with 7-9 pectinate lamellae. Ocelli numerous (12-55) and in several rows (Figs. 48-74); cheeks of male protruding and tongue shaped. Antennae (Figs. 11, 12, 39, 40): composed of 7 antennomeres; antennomeres 6 and 7 with patches of ventral sensillae; tip of antennomere 7 with 4 large sensory cones.

Trunk: anterior ventral segments with thin lateral ridges, rest of trunk relatively smooth and shiny; ozopores from segment 6 until $2^{\text {nd }}$ last segment; anal somite without caudal process (Fig. 24), paraprocts rounded and smooth, usually $2+2$ setae along margin of anal opening.

Legs: first pair of legs of male with broadened femur, setae present only on femur, rounded tarsi, and no distal claws.

Gonopods (male): both pairs of legs of $7^{\text {th }}$ segment modified, forming the copulatory apparatus. Anterior gonopods laterally compressed and complicated in structure, consisting of coxite (sclerite $b$ ) and telopodite, which terminally splits into two sclerites (sclerites $a$ and $c$ ) and a pseudoflagellum. Pseudoflagellum emerges from medial section of sclerite $a$ and extends towards distal end where it detaches from main process. Chitin- 
ous duct extends from within sclerite $a$ to end apically at tip of pseudoflagellum. Posterior gonopods small and unstructured, with few setae on interior surface (Figs. 13, 14, 118).

Distribution: The genus Atelomastix occurs in southern Australia from western Victoria to southwestern Australia, where it has been found in the Darling Ranges, the Western wheatbelt and the southern coast of Western Australia, extending west to east from Walpole to Israelite Bay (Figs. 4-9). Specimens can be found in leaf litter, in the upper-most soil layers, under rocks or under logs. Adults, particularly males, are highly seasonal with the majority of specimens collected during winter and spring.

Remarks: Apart from the features listed above in the generic description, males of Atelomastix may also possess a vestige of the true "julidan-cambalid" flagellum, similar to the one mentioned by Jeekel (1985) in another iulomorphid genus, Victoriocambala. This vestigial flagellum is referred to as the basal process of sclerite $b$.

Nomenclature: The Greek noun mastix refers to a whip and is feminine in gender (Brown 1956). We therefore treat the generic name Atelomastix as feminine.

\section{Key to species of Atelomastix (based solely upon males)}

Remarks: It has not been possible to include A. solitaria in this key due to the lack of illustrations of the anterior gonopods at an appropriate angle (Jeekel 2009).

1. Sclerite $c$ bifurcate, with either deep bifurcation (e.g. Figs. 79, 95, 99, 111, 117, 129, 136) or with small distal teeth (e.g. Figs. 106, 107)

Sclerite $c$ not bifurcate (e.g. Figs. 90, 92, 105).

2. Sclerite $c$ with minute distal bifurcation (Figs. 106, 107).

A. lengae, sp. nov.

Sclerite $c$ with medium to large bifurcation (e.g. Figs. 75, 78, 113, 135).

3. Sclerite $a$ with large externobasal flange (Figs. 87, 114, 120, 135); sclerite $b$ slender with $0-1$ setae on distal margin (Figs. 88, 115, 121, 136).

- Sclerite $a$ without large externobasal flange (Figs. 75, 77, 79, 94, 98, 110, 112, 116, 122, 128); sclerite $b$ thick with at least 2 setae on distal margin (Figs. 76, 78, 80, 95, 99, 111, 113, 117, 123, 129) .....

4. Basal process of sclerite $c$ deeply indented (Fig. 136). A. tumula, sp. nov.

Basal process of sclerite $c$ shallowly indented (Figs. 88, 121, 115)

5. Sclerite $b$ tapering to thin pointed tip (Fig. 115)

A. montana, sp. nov.

- Sclerite $b$ with rounded tip (Figs. 88, 121, 136)

6. Sclerite $b$ without setae (Figs. 87, 88); medial edge of sclerite $c$ broad and medial process of distal bifurcation relatively short (Fig. 88)

A. danksi, sp. nov.

- Sclerite $b$ with 1 seta (Fig. 121); medial edge of sclerite $c$ narrow and medial process of distal bifurcation relatively long (Figs. 120, 121)...

A. poustiei, sp. nov.

7. Sclerite $c$ with basal bifurcation (Figs. 75, 98, 122, 128) .

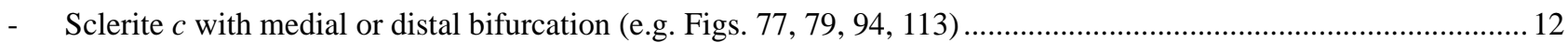

8. Sclerite $c$ with lateral process much smaller than medial process (Figs. 128, 129)..........

A. rubricephala, $\mathrm{sp}$. nov.

Sclerite $c$ with lateral process larger than medial process (Figs. 75, 98, 122).

A. priona, sp. nov.

9. Distal edge of sclerite $b$ deeply serrated (Fig. 123)

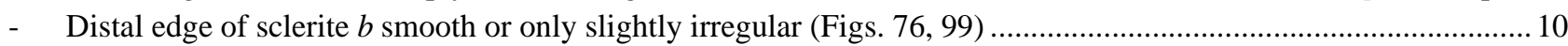

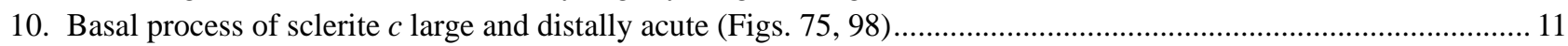

- Basal process of sclerite $c$ low and distally rounded (Fig. 83) ................................................. A. brennani, sp. nov.

11. Distal tip of sclerite $b$ narrowed to fine point (Fig. 76); medial process of sclerite $c$ relatively narrow, with most setae present towards distal end (Figs. 75, 76)

A. albanyensis Attems

- Distal tip of sclerite $b$ not narrowed to fine point (Fig. 99); medial process of sclerite $c$ large and broad, with most setae present basally (Fig. 99).

A. francesae, sp. nov. 
12. Sclerite $\mathrm{c}$ with distal bifurcation (Figs. 77, 94, 112).

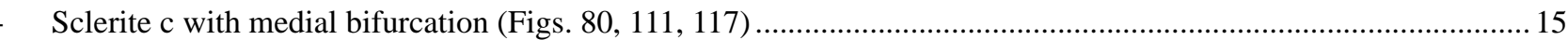

13. Distal hood of sclerite $a$ broad (Figs. 78, 113); pseudoflagellum orientated horizontally, in line with distal edge of sclerite $b$ (Figs. 78, 113); sclerite $b$ with enlarged rounded sub-distal edge, tapering gently to tip (Figs. 78, 113) ... 14

Distal hood of sclerite $a$ short, exposing entire pseudoflagellum, which is orientated vertically in line with neck of sclerite $a$ (Figs. 94, 95); sclerite $b$ elongate, and curved downwards without an enlarged rounded sub-distal edge (Figs. 94, 95).

A. flavognatha, sp. nov.

14. Distal tip of sclerite $c$ generally with small, shallow bifurcation, slightly asymmetrical with angular edges (Figs. 112 , 113)

A. melindae, sp. nov

- Distal tip of sclerite $c$ with asymmetrical tip and shallow bifurcation, medial process noticeably longer than lateral process (Figs. 77, 78).

A. anancita, sp. nov.

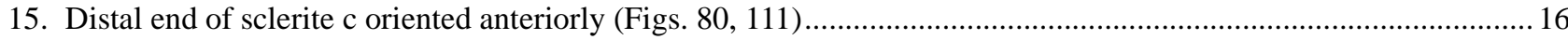

- $\quad$ Distal end of sclerite c oriented medially (Fig. 117).......................................................... A. nigrescens Attems

16. Sclerite $c$ with asymmetrical bifurcation, lateral process longer than medial process (Figs. 110, 111); basal process of sclerite $b$ with rounded tip (Figs. 110,111)

A. mainae, sp. nov.

- $\quad$ Sclerite $c$ with symmetrical bifurcation (Fig. 79); basal process of sclerite $b$ elongate with pointed tip (Figs. 79, 80).

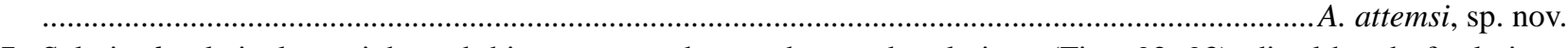

17. Sclerite $b$ relatively straight and thin, not curved around towards sclerite $c$ (Figs. 92, 93); distal hood of sclerite $a$ very small, not extending past end of pseudoflagellum, which is entirely exposed (Figs. 92, 93) ..A. ellenae, sp. nov. Sclerite $b$ curved sub-distally toward sclerite $c$ (e.g. Figs. 82, 131, 133); distal hood of sclerite $a$ curved over pseudoflagellum (e.g. Figs. 82, 131, 133)

18. Sclerite $b$ broadened distally to form an enlarged wedge-shape (Fig. 101); sclerite $c$ short, broad, and slightly indented near distal end (Figs. 100, 101) .................................................................................. gibsoni, sp. nov.

- $\quad$ Sclerite $b$ broad basally, curving sub-distally to form hooked distal tip (e.g. Figs. 82, 90, 105, 109, 133); sclerite $c$

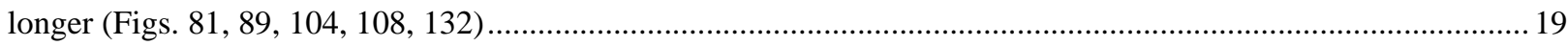

19. Colour of trunk segments dark with yellow orange bands (e.g. Fig. 3) ..............................................................20

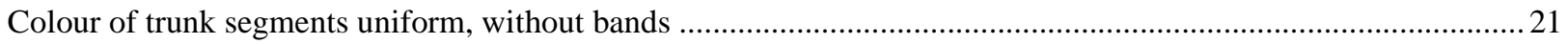

20. Sclerite $b$ with angular distal tip which does not extend to tip of sclerite $c$, basal process very long and thin with sharp point (Figs. 132, 133); distal hood of sclerite $a$ broad, extending to tip of sclerite $b$ (Figs. 132, 133).....

A. tigrina, sp. nov.

- Sclerite $b$ with broad rounded tip that extends to tip of sclerite $c$, basal process longer than wide, but with rounded tip (Figs. 104, 105); distal hood of sclerite $a$ does not extend to distal tip of sclerite $b$ (Figs. 104, 105)

21. Sclerite $c$ curved (Figs. 90, 131)

A. julianneae, sp. nov.

22. Sclerite $b$ very long and elongate, curved to form a hook that extends beyond edge of sclerite $c$ (Figs. 89, 90).........

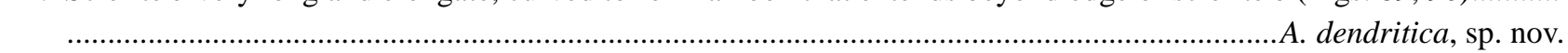

Sclerite $b$ not very long and elongate (Figs. 130, 131)

.. A. sarahae, sp. nov.

23. Sclerite $b$ with setae extending to distal end (Fig. 109).....

A. longbottomi, sp. nov.

Sclerite $b$ with setae not extending to distal end (Figs. 82, 86, 103, 126)

24. Sclerite $b$ with pointed distal tip, basal process as wide as long (Fig. 103); sclerite $c$ with sub-distal indentation and broad distal tip (Figs. 102, 103); sclerite $a$ with deep distal hood and entirely exposed vertically orientated pseudoflagellum (Figs. 102, 103)......

A. grandis, sp. nov.

- Sclerite $b$ with rounded distal tip, basal process wider than long (Figs. 82, 86, 126); sclerite $c$ without sub-distal indentation (Figs. 81, 85, 125); sclerite $a$ without deep distal hood, pseudoflagellum curved and lying within sclerite $a$ (Figs. 82, 86, 126)

25. Sclerite $c$ narrow and generally straight distally with rounded, sometimes slightly asymetrical tip, shallow concavity present on interno-lateral side (Figs. 125, 126)

.A. psittacina, sp. nov.

- $\quad$ Sclerite $c$ slightly thickened and curved distally (Figs. 81, 85)...

26

26. Sclerite $c$ broadened distally (Figs. 81, 82); sclerite $b$ broad with small pointed distal tip (Figs. 81, 82)......

A. bamfordi, sp. nov.

A. culleni, sp. nov. 


\section{Atelomastix albanyensis Attems}

Figs. 6, 48, 75, 76.

Atelomastix albanyensis Attems 1911: 194-195, Figs. 73-80 (in part, see A. mainae, sp. nov.); Attems 1914: 293; Chamberlin 1920: 167; Verhoeff 1924: 133; Jeekel 1971: 107.

Type material: AUSTRALIA: Western Australia: lectotype male, Albany, Hamburger südwest-australischen

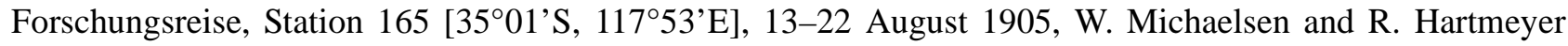
(ZMH). Paralectotypes: 4 females, same data (ZMH); 1 female, same data (ZMB 5162); 1 male, same data except 13 August 1905 (WAM 13/7145; misidentified, see A. mainae, sp. nov.).

Other material examined: AUSTRALIA: Western Australia: 1 male, 1 female, Two Peoples Bay Nature Reserve, bottom of gully, 34 $59^{\prime} 53^{\prime \prime S}, 118^{\circ} 11^{\prime} 52^{\prime \prime}$, wet pitfall traps, 26 July 1994, S. Comer (WAM T76043); 1 male, Tick Flat, Two Peoples Bay Nature Reserve, below A-frame, 3459'26”S, 118¹0'57'E, wet pitfall traps, 26 July 1994, S. Comer (WAM T76042); 5 males, 4 females, 3 juveniles, Cranbrook Tower Hill, Cranbrook, 34 $18^{\prime} 00^{\prime \prime} S, 117^{\circ} 35^{\prime} 39^{\prime \prime} \mathrm{E}$, hand collected under laterite rocks, 16 June 2007, M.L. Moir (WAM T83176, T81090).

Diagnosis: Atelomastix albanyensis differs from all other species except $A$. francesae through a deeply bifurcated sclerite $c$. It can be distinguished from $A$. francesae by the shape of sclerites $b$ and $c$. Sclerite $b$ is slightly curved and tapers to a sharp point distally compared to being blunt and broadly shaped. The medial process of sclerite $c$ is relatively narrow, with most setae present towards the distal end, and the lateral process is distally curved and pointed.

Description: Male (WAM T76043). Colour: legs, gonopods and mouthparts yellow, segments mottled blue-grey; prozonites yellow, salmon to blue grey; metazonites blue-grey to yellow/pink in preserved specimens.

Body: ca. $21 \mathrm{~mm}$ long and ca. $1.7 \mathrm{~mm}$ wide at collum. With 42 trunk segments 73 pairs of legs, last 2 segments without legs.

Head: with 39 ocelli (Fig. 48), arranged in 6 rows (3: 5: 7: 8: 9: 7).

Gonopods: anterior gonopods (Figs. 75, 76) lightly sclerotised, 2.5 times longer than broad; sclerite $a$ with swollen base that forms broad, curved distal hood; upper distal face of sclerite $a$ with 15-17 (n=4) short blunt setae; pseudoflagellum relatively short and partially visible beneath distal hood; sclerite $b$ relatively broad and curved distally forming sharp hook, with 5-7 setae $(\mathrm{n}=4)$; basal process of sclerite $b$ small and triangular, 0.02 times length of main process; sclerite $c$ deeply bifurcate, lateral process much longer than medial process and with curved distal hook, medial process triangular in shape, tapering to sharp tip, with 6 setae spread over middle of process and 2 setae below bifurcation; clump of 5 sub-basal setae present where sclerites overlap and group of 11 short setae sub-basally on sclerite $c$; anterior gonopods inconspicuous, small, with several small setae on interno-lateral face of each gonopod.

Dimensions (mm): male, WAM T76043 (male, WAM T76042): length ca. 21, width ca. 1.7; L/W=12.7; sclerite $a 1.088 / 0.429(1.128 / 0.422)$, setae $16(17)$; sclerite $b 0.442(0.474)$, basal process of sclerite $b 0.008$ (0.009), setae 6 (7); sclerite $c 0.880(0.896)$, lateral process of sclerite $c 0.263(0.282)$, medial process of sclerite $c 0.131(0.173)$, setae $8(8)$.

Female. Similar to male, other than sexual characters, and slightly larger.

Remarks: The type series of $A$. albanyensis actually consists of two species. The male syntype from Albany (Station 165) (WAM 13/7145) has a male genital morphology different from that illustrated by Attems (1911), and belongs to the new species described below as Atelomastix mainae sp. nov. This specimen was not dissected by Attems, but our dissection and examination of the gonopods has shown that it is not conspecific with the specimen illustrated by Attems (1911). The only other male available to us is lodged in ZMH and presumably formed the basis of Attems' (1911) description of A. albanyensis. However, the head and gonopods of this specimen are not included in the vial and appear to be lost. Nevertheless, Attems' illustration of the 
male gonopods perfectly matches recently collected specimens from Two Peoples Bay and Cranbrook (Fig. 6), and without hesitation we ascribe these specimens to A. albanyensis. It is impossible to identify female specimens of Atelomastix to species level, and we cannot be certain of the identity of the female type specimens. However, we retain them as specimens of A. albanyensis. With the type series consisting of two species, we nominate the male lodged in ZMH as lectotype, despite the loss of the male gonopods. This action retains Attems' (1911) concept of this species. The remaining specimens, consisting of five females and one male from Albany, are designated as paralectotypes. As discussed above, the male paralectotype is identified as a specimen of A. mainae, and is listed under that species.

Distribution and habitat: Although A. albanyensis was first described from specimens purported to have been collected in Albany (Attems 1911), we have not found the species near Albany, but have found specimens with gonopod morphology identical to that illustrated by Attems (1911) from Two Peoples Bay Nature Reserve and Cranbrook (Fig. 6). It may be possible that the original specimens of A. albanyensis were collected in the Albany area, but not within Albany itself.

\section{Atelomastix anancita, sp. nov.}

Figs. 8, 49, 77, 78.

Type material: AUSTRALIA: Western Australia: holotype male, Mount Diamond, Cape Arid National Park,

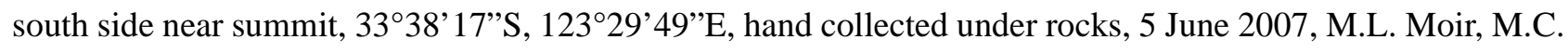
Leng (WAM T83177). Paratypes: 1 male, collected with holotype (WAM T83178); 23 males, 6 females, collected with holotype (WAM T80681); 6 males, 18 females, collected with holotype (WAM T80682); 1 female, collected with holotype (WAM T80683); 2 males, 2 males, Mount Arid, Cape Arid National Park, south side near summit, 335' $45^{\prime}$ 'S, $123^{\circ} 13^{\prime} 01^{\prime}$ E, hand collected under granite rocks, 5 June 2007, M.L. Moir, M.C. Leng (WAM T80673).

Etymology: The species epithet is an adjective based on the type locality, Mount Diamond (anancitus, Latin, a name for the diamond when used as a remedy for distress of the mind).

Diagnosis: The male gonopod morphology of Atelomastix anancita is similar to that of A. melindae and A. flavognatha, as it has a distally bifurcated sclerite $c$ and the tip of sclerite $b$ extends between the bifurcation and beyond the edge of sclerite $c$. It can be distinguished from these species as the medial process of the sclerite $c$ bifurcation is noticeably much longer than the lateral process. The distal end of sclerite $b$ is elongate, not distinctly curved, and tapers gently to a rounded tip. Setae are situated only on the subdistal curved edge of sclerite $b$ and do not extend towards the distal tip as in A. melindae.

Description: Male (holotype). Colour: generally mottled blue-grey, legs, mouthparts, gonopods golden brown; prozonites dark brown to pale brown, metazonites blue-grey in preserved specimens.

Body: ca. $34 \mathrm{~mm}$ long and ca. $2.3 \mathrm{~mm}$ wide at collum. With 56 trunk segments, 101 pairs of legs, last 2 segments without legs.

Head: with ca. 55 ocelli (Fig. 49), arranged in 7 rows (4: 8: 10: 10: 9: 8: 6).

Gonopods: anterior gonopods (Figs. 77-78) of medium to heavy sclerotisation, 2.2 times longer than broad; sclerite $a$ with swollen base that forms broad, curved distal hood; upper distal face of sclerite $a$ with 12-28 $(n=2)$ short blunt setae; pseudoflagellum relatively short, fat and mostly visible beneath distal hood; sclerite $b$ relatively narrow, tip extending between bifurcation and beyond edge of sclerite, tapering to blunt tip distally, with 7-11 sub-distal setae; basal process of sclerite $b$ small, 0.06 times length of main process; sclerite $c$ similar height as sclerite $b$, shallowly bifurcate, medial process longer, with 5-7 setae $(\mathrm{n}=2)$ below bifurcation; sub-basal setae absent where sclerites overlap and group of 7-8 $(n=2)$ short setae sub-basally on sclerite $c$; posterior gonopods inconspicuous, small, with several small setae on interno-lateral face of each gonopod. 
Dimensions (mm): holotype male (paratype male, WAM T83178): length ca. 34, width ca. 2.3, L/W=12.7; sclerite $a 1.344 / 0.621(1.265 / 0.525)$, setae $28(12)$; sclerite $b 0.403(0.422)$, basal process of sclerite $b 0.026$ (0.032), setae 7 (11); sclerite $c 0.960$ (0.912), lateral process 0.045 (0.067), medial process $0.115(0.093)$, setae 5 (7).

Female. Similar to male, other than sexual characters, and slightly larger.

Distribution and habitat: Atelomastix anancita is only known from rocky outcrops near the summit of Mount Diamond and Mount Arid in Cape Arid National Park (Fig. 8). All specimens were collected from beneath rocks.

\section{Atelomastix attemsi, sp. nov.}

Figs. 6, 50, 79, 80 .

Type material: AUSTRALIA: Western Australia: holotype male, Millinup Pass, south entrance, Porongurup Range National Park, 3441'47'S, 117 53'56'E, hand collected under logs, 28 July 2003, K.L. Edward (WAM T47956). Paratypes: 2 males, collected with holotype (WAM T69763); 6 males, collected with holotype (WAM T69764); 1 male, Picnic area on Bolganup Road, Porongurup Range National Park, 3440'33”S, 11752'17’'E, hand collected under logs, 28 July 2003, K.L. Edward (WAM T69747).

Other material examined: AUSTRALIA: Western Australia: Porongurup Range National Park: 7 males, collected with holotype (WAM T69754-T69760); 19 males, 29 females, Picnic area on Bolganup Road, 3440'33"S, 11752'17'E, hand collected under logs, 28 July 2003, K.L. Edward (WAM T69746, T69748T69753); 6 males, 5 females, Waddy's Hut area, 3440'57'S, 11750'56”'E, hand collected under logs, 7 April 2004, M.S. Harvey, J.M. Waldock, K.L. Edward, B.Y. Main (WAM T69940, T94887); 2 males, south end of Millinup Pass, 3441'43'S, 11753'51'E, wet pitfall traps, 28 April 1996-2 August 1996, M.S. Harvey et al. (WAM T47925); 1 male, south end of Millinup Pass, 3441'43”S, 11753'51'E, hand collected under rotting logs, 30 March 1993, M.S. Harvey, J.M. Waldock (WAM T47935); 5 males, 8 females, Millinup Pass, 3441'15"S, 11754'12”'E, tullgren funnel leaf litter, 3 November 2006, M.L. Moir, D. Jolly (WAM T81062);

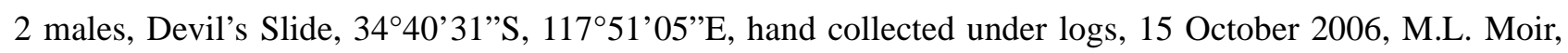
J.M. Waldock (WAM T78586); 6 males, 22 females, Hayward Peak, 3440’28’'S, 11753'51'”, hand collected in leaf litter, 15 June 2007, M.L. Moir (WAM T80835); 4 males, 10 females, Hayward Peak, 3440'37'S, 117 53'44”'E, hand collected in leaf litter, 15 June 2007, M.L. Moir (WAM T80834); 9 males, 22

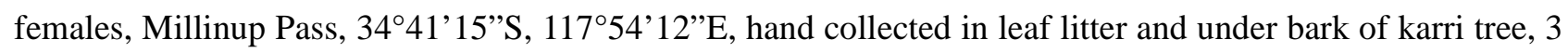
November 2006, M.L. Moir, D. Jolly (WAM T78733); 6 males, 16 females, Twin Peaks, burnt karri forest, 3441'13”S, 117 54'06”'E, hand collected under burnt logs, 15 June 2007, M.L. Moir (WAM T80833); 3

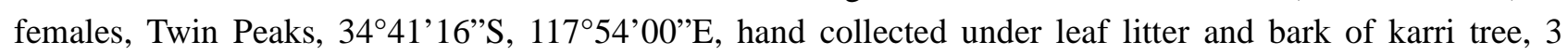
November 2006, M.L. Moir, D. Jolly (WAM T78735); 1 female, Devil's Slide, 3440’27’S, 11751'07’E, hand collected under rocks and logs, 15 October 2006, M.L. Moir, J.M. Waldock (WAM T78584).

Etymology: The specific epithet is a patronym in honour of Carl Graf Attems, who described the genus Atelomastix in 1911.

Diagnosis: This species is similar to Atelomastix mainae, but differs in the shape and size of lateral and medial processes of sclerite $c$, the shape of sclerite $b$, the shape of the basal process of sclerite $b$, and the absence of a sub-basal seta. In A. attemsi the lateral and medial processes are broad and relatively symmetrical compared to A. mainae. Also, sclerite $b$ is relatively much thinner, with distinct curvature, and well developed setae at the sub-distal end. The basal process of this sclerite is thinner and longer than the process seen in $A$. mainae.

Description: Male (holotype). Colour: Collum and anal segment dark brown; head, mouth parts, antennae, gonopod, ozopores and legs golden-brown; prozonites blue-grey, metazonites pale golden brown. 
Body: ca. $17 \mathrm{~mm}$ long and ca. $1.3 \mathrm{~mm}$ wide at collum. With 41 trunk segments, 67 pairs of legs, last 4 segments without legs.

Head: with ca. 16 ocelli (Fig. 50), arranged in 4 rows (1:3:5:7).

Gonopods: anterior gonopods (Figs. 79, 80) large and complex in structure, 2.60 times longer than broad; sclerite $a$ with swollen base and broad, curved distal hood; upper distal face of sclerite $a$ with 20 short blunt setae; pseudoflagellum short, broad, and partially concealed within broadened distal hood; sclerite $b$ elongate, curving to rounded hook at distal end, not extending to edge of sclerite $c$, with 3-7 relatively large setae on subdistal edge $(\mathrm{n}=3)$; basal process of sclerite $b$ very long, tapering to narrow rounded end, 0.23 times length of main process; sclerite $c$ bifurcate, same height as sclerite $b$, lateral and medial processes symmetrical, each tapering to blunt rounded tip, with 4-5 setae $(n=3)$ positioned below division of lateral and medial processes; without sub-basal seta on sclerite $c$; posterior gonopods inconspicuous, small, with several small setae on interno-lateral face of each gonopod.

Dimensions (mm): holotype male (paratype male, WAM T69747): length ca. 17, width ca. 1.3 (L/ $\mathrm{W}=13.1)$; sclerite $a 0.883 / 0.340(0.966 / 0.442)$, setae 20 ; sclerite $b 0.366(0.429)$, basal process of sclerite $b$ $0.085(0.070)$, setae $3(5)$; sclerite $c 0.586(0.648)$, lateral process of sclerite $c 0.103(0.120)$, medial process of sclerite $c 0.104$ (0.108), setae 4 (5).

Female. Similar to male, other than sexual characters, and slightly larger.

Distribution and habitat: This species is only known from three sites in the Porongurup Range National Park, situated approximately $34 \mathrm{~km}$ north of Albany (Fig. 6). The dominant vegetation in this area includes tall karri (Eucalyptus diversicolor) forests and mixed karri, jarrah (E. marginata) and marri (Corymbia calophylla) forests. Specimens were collected by hand from under rotting logs. This species occurs with A. julianneae, although the level of sympatry is not currently known.

\section{Atelomastix bamfordi, sp. nov.}

Figs. 4, 51, 81, 82 .

Type material: AUSTRALIA: Western Australia: holotype male, Mount Jackson area, 30¹3'30"S, $119^{\circ} 09^{\prime} 40 " \mathrm{E}$, hand collected under leaf litter, 18 August 2006, W. Bancroft, B. Metcalf (WAM T86853). Paratypes: 2 males, collected with holotype (WAM T86851); 1 male, 2 females, collected with holotype (WAM T86852).

Other material examined: AUSTRALIA: Western Australia: Marvel Loch, St Barbara Operation: 2

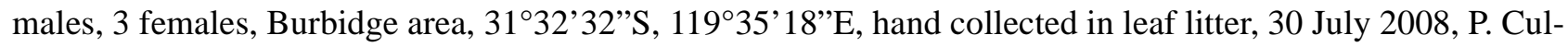
len, P. Langlands (WAM T96101, T96088); 3 males, same data except 31³3'33”S, 119³4'27'E (WAM T96084, T96091, T96093); 2 males, 2 females, same data except 31³3'33”S, 119³4’06”'E (WAM T96095); 2 males, 2 females, Cornishman area, 31 19'19”S, 119²4'02”E, hand collected in leaf litter, 1 August 2008,

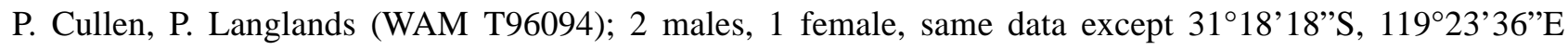

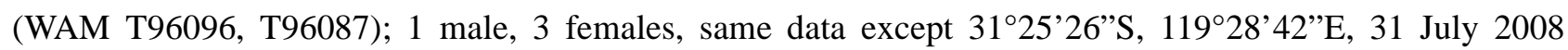
(WAM T96092); 1 male, same data except 31 ${ }^{\circ} 17^{\prime} 17^{\prime \prime}$ S, 119²2'14'E (WAM T96099); 2 males, 1 female, Transvaal area, $31^{\circ} 17^{\prime} 18^{\prime \prime} \mathrm{S}, 11^{\circ} 19^{\prime} 36^{\prime \prime} \mathrm{E}$, hand collected in soil, 29 July 2008, P. Cullen, P. Langlands (WAM T96098, T96100). Koolyanobbing: 2 males, 3 females, Koolyanobbing Range, 3048'S, 119³5'E, beneath rocks of ironstone hills, 31 July 2007, M. Bamford (WAM T67125); 1 male, 10.0 km SE of Koolyanobbing, 30'52'13.2”'S, 119 36'14.1'E, hand collected in leaf litter, 19 August 2009, R. Teale (WAM T98805); 2 males, 3 females, same data except $10.5 \mathrm{~km}$ SE of Koolyanobbing, 3052'22.94”S, 119³6’31.25’'E (WAM T98814-98818); 1 male, 3 females, same data except 10.7 km SE of Koolyanobbing, 3052'25.10”'S, 119³6’31.25”'E (WAM T98819-98822); 3 males, 2 females, same data except 3052’25.3”S, 119³6’49.1’'E (WAM T98828-98832); 4 males, 2 females, same data except $11 \mathrm{~km}$ SE of Koolyanobbing, 
30'52'27.7'S, 119³6'43.9'E (WAM T98823-98827, T98851); 2 males, 1 female, same data except $12.5 \mathrm{~km}$ SE of Koolyanobbing, 3053'26.7'S, 119³7'05.2”E, 21 August 2009 (WAM T98838-98840); 2 males, 2 females, $13.2 \mathrm{~km}$ SE of Koolyanobbing, 3053'07'S, 119³7'59.7’'E, 20 August 2009 (WAM T9883498837); 4 males, 2 females, same data except 3.5 km SE of Koolyanobbing, 3050'25.4”S, 119'32’32.8'E, 23 August 2009 (WAM T98846-98850); 1 male, 3 females, same data except $5.5 \mathrm{~km}$ SE of Koolyanobbing, 30 51'06.5"S, 119³3'43.1'E (WAM T98843-98845); 1 male, same data except $6.7 \mathrm{~km}$ SE of Koolyanobbing, 3051'13.5'S, 119³4'26.8'E, 22 August 2009 (WAM T98842); 2 males, 4 females, same data except $9.9 \mathrm{~km}$ SE of Koolyanobbing, 3052'12.25”'S, 119³6'14.29'E, 19 August 2009 (WAM T98806, T9880898809, T98811-98813). Windarling: 5 males, 2 females, 91.0 km NNW of Koolyanobbing, 3000'34.7'S, 119¹8'53.1'E, 15 August 2009, R. Teale (WAM T98794-98800); 9 males, 5 females, same data except 91.3 km NNW of Koolyanobbing, 3000'36”S, 119¹8'44.03”'E, 14 August 2009 (WAM T98780-98793); 6 males, 4 females, same data except $91.3 \mathrm{~km}$ NNW of Koolyanobbing, 3000’39.6”S, 119¹8'50.11”'E, 17 August 2009 (WAM T98801-98804, T98807, T98810).

Etymology: The specific epithet is a patronym in honour of Mike Bamford who has collected other species of Atelomastix in Western Australia.

Diagnosis: Atelomastix bamfordi differs from other species by the short, broad distal end of sclerite $c$. Also, sclerite $b$ is much longer than sclerite $c$, is relatively broad and short, curved sub-distally, and tapers slightly to form a very small pointed tip. The distal hood of sclerite $a$ is very broad and extends past the tip of sclerite $b$ and $c$ and almost entirely obscures the short pseudoflagellum.

Description: Male (holotype). Colour: generally yellow-brown, legs brown, gonopods golden brown; prozonites mottled chocolate brown, metazonites mottled chocolate brown in preserved specimens.

Body: ca. $33 \mathrm{~mm}$ long and ca. $2.2 \mathrm{~mm}$ wide at collum. With 53 trunk segments, 95 pairs of legs, last 2 segments without legs.

Head: with ca. 48 ocelli (Fig. 51), arranged in 6 rows (4: 7: 9: 10: 11: 7).

Gonopods: anterior gonopods (Figs. 81, 82) with light to medium sclerotisation, 2.2 times longer than broad; sclerite $a$ with swollen base that forms very broad, curved distal hood that extends beyond tip of sclerite $b$; upper distal face of sclerite $a$ with 24 short blunt setae; pseudoflagellum relatively short and almost entirely obscured beneath broad distal hood; sclerite $b$ broad, curved sub-distally, slightly tapering to form a very small pointed tip, with 9 short setae; basal process of sclerite $b$ short, 0.04 times length of main process; sclerite $c$ much shorter than sclerite $b$, without concavity, but indented slightly sub-distally, with broadened distal tip, with 5 setae near indentation; sub-basal setae not visible where sclerites overlap and group of 11 short setae sub-basally on sclerite $c$; posterior gonopods inconspicuous, small, with several small setae on interno-lateral face of each gonopod.

Dimensions $(\mathrm{mm})$ : holotype male: length ca. 33, width ca. 2.2, $\mathrm{L} / \mathrm{W}=15.0$; sclerite $a 1.288 / 0.589$, setae 24; sclerite $b 0.443$, basal process of sclerite $b 0.035$, setae 9 ; sclerite $c 0.867$, setae 5 .

Female. Similar to male, other than sexual characters, and slightly larger.

Distribution and habitat: This species occurs at several locations in the central wheatbelt region of Western Australia (Fig. 4), including the Koolyanobbing and Windarling Ranges, Marvel Loch, and Mt Jackson. The specimens were found in or under leaf litter, in soil or under stones.

\section{Atelomastix brennani, sp. nov.}

Figs. 7, 52, 83, 84 .

Type material: AUSTRALIA: Western Australia: holotype male, Mount Le Grand, Le Grand National Park, summit, 33 ${ }^{\circ} 59^{\prime} 41^{\prime \prime}$ S, $122^{\circ} 07^{\prime} 48^{\prime \prime} \mathrm{E}$, hand collected under granite rocks, 4 June 2007, M.L. Moir, M.C. Leng (WAM T83222). Paratypes: Mount Le Grand, Le Grand National Park: 21 males, 24 females, collected with 
holotype (WAM T80738, T80736); 6 males, 11 females, outcrop about Rossiter Bay, 3359’26”S, 122 $2^{\circ} 5^{\prime} 34^{\prime \prime} \mathrm{E}$, hand collected under granite rocks, 4 June 2007, M.L. Moir, M.C. Leng (WAM T80727, T80801).

Other material examined: AUSTRALIA: Western Australia: Mount Le Grand, Le Grand National Park: 9 males, 9 females, Mississippi Hill, 33 ${ }^{\circ} 59^{\prime} 39^{\prime}$ 'S, 122 ${ }^{\circ} 15^{\prime} 16^{\prime}$ 'E, hand collected under granite rocks, 4 June 2007, M.L. Moir, M.C. Leng (WAM T80720, T80719); 1 male, 5 females, gully east of Mississippi Hill, 3359'06”S, $122^{\circ} 15^{\prime} 37^{\prime}$ 'E, hand collected under rotting log, 4 June 2007, M.L. Moir, M.C. Leng (WAM T80718).

Etymology: The specific epithet is a patronym in honour of Karl Brennan who has collected other species of Atelomastix in southwestern Australia.

Diagnosis: Atelomastix brennani can be distinguished from other species as sclerite $c$ is curved, but not bifurcate, with a very shallow lateral concavity, and the distal tip is in line with the distal tip of sclerite $b$. Sclerite $b$ is curved distally to a narrow point and overlaps with the tip of sclerite $c$. The broadened distal hood of sclerite $a$ is curved over touching edge of sclerite $b$.

Description: Male (holotype). Colour: legs lighter brown, mouthparts yellow brown, anal segments dark brown; prozonites mottled dark brown, metazonites mottled dark brown to light fawn in preserved specimens.

Body: ca. $34 \mathrm{~mm}$ long and ca. $2.1 \mathrm{~mm}$ wide at Collum. With 58 trunk segments, 103 pairs of legs, last 3 segments without legs.

Head: with ca. 43 ocelli (Fig. 52), arranged in 7 rows (2: 4: 7: 9: 8: 7: 6).

Gonopods: anterior gonopods (Figs. 83, 84) with light to medium sclerotisation, 2.3 times longer than broad; sclerite $a$ with swollen base that forms broad, curved distal hood, overlapping with distal edge of sclerite $b$; upper distal face of sclerite $a$ with 17-32 ( $\mathrm{n}=2)$ short blunt setae; pseudoflagellum entirely obscured beneath broad distal hood; sclerite $b$ rounded anteriorly, curved distally and tapering to a sharp point overlapping with tip of sclerite $c$, with 15-20 (n=2) short setae in two rows along sub-distal edge; basal process of sclerite $b$ short, 0.02 times length of main process; sclerite $c$ shorter than sclerite $b$, slightly concave on interno-lateral surface, curved subdistally to rounded tip, with 3-7 $(n=2)$ setae medially; sub-basal setae absent where sclerites overlap and group of $14(\mathrm{n}=2)$ short setae sub-basally on sclerite $c$; posterior gonopods inconspicuous, small, with several small setae on interno-lateral face of each gonopod.

Dimensions (mm): holotype male (paratype male, WAM T80738): length ca. 34, width ca. 2.1, L/W=16.2; sclerite $a 1.280 / 0.557$ (1.26/0.557), setae 17 (32); sclerite $b 0.470(0.486)$, basal process of sclerite $b 0.02$ (0.02), setae 20 (15); sclerite $c 0.960$ (0.928), setae 7 (3).

Female. Similar to male, other than sexual characters, and slightly larger.

Distribution and habitat: This species is known from four localities in the Le Grand National Park, near the summit of Mount Le Grand, Rossiter Bay and Mississipi Hill (Fig. 7). Specimens were collected from the soil or under granite rocks. This species occurs with A. grandis near the summit of Mount Le Grand, and A. brennani is noticeably smaller than A. grandis.

\section{Atelomastix culleni, sp. nov.}

Figs. 7, 53, 85, 86 .

Type material: AUSTRALIA: Western Australia: holotype male, Bremer Bay, near Cape Knob, 34²9'40”S, 119¹6'29'E, hand collected under leaf litter, 7 June 2007, M.L. Moir, M.C. Leng (WAM T83163). Paratypes: 12 males, 18 females, collected with holotype (WAM T80650, T80651); 1 male, 2 females, Mount Groper, in gully, 34²9’29’'S, 118 53’31'E, hand collected under leaf litter, 25 October 2006, M.L. Moir, A. Sampey (WAM T78621); 1 male, 2 females, Mount Groper, in gully, 34²9'29'S, 118 53'31'E, extracted from leaf litter using tullgren funnel, 25 October 2006, M.L. Moir, A. Sampey (WAM T81061); 2 males, 2 females, 
Mount Groper, in gully, 34²9'23”S, 118 53'43”E, hand collected under leaf litter, 25 October 2006, M.L. Moir, A. Sampey (WAM T78623).

Other material examined: AUSTRALIA: Western Australia: 1 female, collected with holotype (WAM T80652); 3 females, Mount Groper, in gully, 34²9’32”S, 1853’30”E, hand collected under leaf litter, 25 October 2006, M.L. Moir, A. Sampey (WAM T78778, T81060); 2 females, Mount Groper, in gully, 34'29'29'S, 118 53'31'E, hand collected under leaf litter, 25 October 2006, M.L. Moir, A. Sampey (WAM T78620); 3 females, Mount Groper, in gully, 34²9'24’'S, 11853'48’E, hand collected under leaf litter, 25 October 2006, M.L. Moir, A. Sampey (WAM T78777); 1 female, Mount Groper, in gully, 34²9’23”S, 118 53'43"E, hand collected under leaf litter, 25 October 2006, M.L. Moir, A. Sampey (WAM T78622); 1 female, Cape Knob, Cave Hill, granite overhang, 34³0'50”S, 119¹7’50”E, 13 January 2007, N. McQuoid (WAM T78953).

Etymology: The specific epithet is a patronym in honour of Patrick Cullen.

Diagnosis: The male gonopod morphology of Atelomastix culleni is similar to A. psittacina as sclerite $a$ has a broad distal hood that curves around to overlap sclerite $b$ and obscure the pseudoflagellum. However, it can be distinguished from A. psittacina as sclerite $b$ is not significantly curved into a distal hook, and sclerite $c$ is straight and broadened distally with a shallow concavity directed laterally.

Description: Male (holotype). Colour: generally chocolate brown; legs, anal segment and antennae light brown; prozonites mottled brown, metazonites mottled brown in preserved specimens.

Body: ca. $24 \mathrm{~mm}$ long and ca. $1.8 \mathrm{~mm}$ wide at collum. With 47 trunk segments, 81 pairs of legs, last 3 segments without legs.

Head: with ca. 38 ocelli (Fig. 53), arranged in 6 rows (2: 5: 5: 8: 8:10).

Gonopods: anterior gonopods (Figs. 85, 86) with medium sclerotisation, 2.2 times longer than broad; sclerite $a$ with swollen base that forms broad, curved distal hood that overlaps and extends to tip of sclerite $b$; upper distal face of sclerite $a$ with 21-38 (n=2) short blunt setae; pseudoflagellum relatively short and partially visible beneath distal hood; sclerite $b$ curved distally, forming blunt elongate tip, with $8-14(\mathrm{n}=2)$ short setae; basal process of sclerite $b$ short, triangular, 0.08 times length of main process; sclerite $c$ shorter than sclerite $b$, not bifurcate, tapering slightly to broad tip, 4-6 setae sub-medially; sub-basal setae absent where sclerites overlap and group of $11-14(\mathrm{n}=2)$ short setae sub-basally on sclerite $c$; posterior gonopods inconspicuous, small, with several small setae on interno-lateral face of each gonopod.

Dimensions (mm): holotype male (paratype male, WAM T78621): length ca. 24, width ca. 1.8, L/W=13.2; sclerite $a 1.216 / 0.543(1.520 / 0.720)$, setae 21 (38); sclerite $b 0.458(0.512)$, basal process of sclerite $b 0.038$ (0.038), setae 8 (14); sclerite $c 0.768$ (0.960), setae 4 (6).

Female. Similar to male, other than sexual characters, and slightly larger.

Distribution and habitat: Atelomastix culleni is only known from Bremer Bay and Mount Groper (Fig. 7). Specimens were collected from leaf litter taken from forested gullies dominated by Eucalyptus, Melaleuca and Agonis.

Atelomastix danksi, sp. nov.

Figs. 5, 34-47, 54, 87, 88.

Type material: AUSTRALIA: Western Australia: holotype male, Toolbrunup Peak, Stirling Range National Park, 34²3'27'S, 11803'31'”E, hand collected in creek line, 5 April 2004, M.S. Harvey, J.M. Waldock, K.L. Edward, C. Poustie (WAM T47957). Paratypes: 3 males, 2 females, collected with holotype (WAM T70203); 1 male, Toolbrunup Peak, Stirling Range National Park, 34²3'29"S, $118^{\circ} 03^{\prime} 43$ "E, hand collected under logs, 28 July 2003, K.L. Edward (WAM T69766).

Other material examined: AUSTRALIA: Western Australia: 4 males, 30 females, Toolbrunup Peak, Stirling Range National Park, 34²3’29"S, 11803’43"E, hand collected under logs, 28 July 2003, K.L. 
Edward (WAM T69765, T69767-T69771); 2 males, Toolbrunup Peak, Stirling Range National Park, 342'ㄱ'S"S, 11803'32”'E, wet pitfall traps, 3 August-19 December 1996, M.S. Harvey, J.M. Waldock, B.Y. Main (WAM T47926).

Etymology: The specific epithet is a patronym in honour of Alan Danks.

Diagnosis: Atelomastix danksi is similar to other Atelomastix species found on the eastern side of the Stirling Range, as the anterior gonopod sclerite $a$ is broad and concave sub-medially enveloping an elongate pseudoflagellum beneath a broad distal hood. Live specimens are large (body width $2.27 \mathrm{~mm}$ ) and generally have a blue-grey colouration with pale bands. However, it can be distinguished from A. montana, A. tumula, and $A$. poustiei by the lack of a medial bifurcation of sclerite $c$, the symmetrical shallow distal bifurcation of sclerite $c$, and the tip of sclerite $b$ is rounded, curved sub-distally, and only slightly tapering. Atelomastix tumula and A. poustiei also possess setae on sclerite $b$, which are lacking in $A$. danksi.

Description: Male (holotype). Colour: live specimens dark blue-grey with lighter bands between segments; head, collum, mouth parts, antennae, gonopods, ozopores and legs golden-brown, anal segment bluegrey, prozonites blue-grey, metazonites brown to yellow-brown in preserved specimens.

Body: ca. $43 \mathrm{~mm}$ long and ca. $2.3 \mathrm{~mm}$ wide at collum. With 59 trunk segments, 104 pairs of legs, last 2 segments without legs.

Head (Fig. 34, 35): with ca. 34 ocelli (Fig. 54), arranged in 4 rows (7: 8: 9: 10).

Gonopods: anterior gonopods (Figs. 41-46, 87, 88) very large, heavily sclerotised and complex in structure, 2.09 times longer than broad; sclerite $a$ with swollen base that forms broad, concave area where pseudoflagellum emerges, and broad, curved distal hood; sub-distal edge of concave area of sclerite $a$ with 4 larger setae; upper distal face of sclerite $a$ with 27 short blunt setae; pseudoflagellum long, elongate and partially concealed within broadened distal hood; sclerite $b$ elongate and curved, terminating in a blunt, rounded hook, without setae; basal process of sclerite $b$ large, triangular, tapering to form sharp tip, 0.39 times the length of the main process; sclerite $c$ same height as sclerite $b$, not bifurcate, broad and concave medially, slightly tapering to a blunt tip, with 6-10 setae $(n=6)$ on internal concave face; with group of 3-8 $(n=6)$ fine setae on subbasal edge of sclerite $b$ instead of single sub-basal setae where sclerites overlap; anterior gonopods inconspicuous, small, with several small setae on interno-lateral face of each gonopod.

Dimensions (mm): holotype male (paratype male, WAM T69766): length ca. 43, width ca. 2.3 (L/ $\mathrm{W}=18.8$; sclerite $a 1.206 / 0.577$ (1.12/0.608), setae 27; sclerite $b 0.512(0.506)$, basal process of sclerite $b$ 0.198 (0.166), basal process of sclerite $b 0.198(0.166)$, setae $0(0)$; sclerite $c 0.930(0.896)$, setae 7 (7).

Female. Similar to male, other than sexual characters, and slightly larger.

Distribution and habitat: This species has only been recorded from the base of Toolbrunup Peak in the Stirling Range National Park (Fig. 5) and specimens were collected alongside a seasonally dry creek bed using pitfall traps, or from under eucalypt logs.

\section{Atelomastix dendritica, sp. nov.}

Figs. 8, 55, 89-91.

Type material: AUSTRALIA: Western Australia: holotype male, Woody Island, Recherche Archipelago,

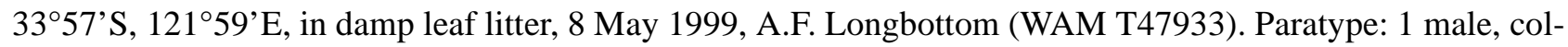
lected with holotype (WAM T74296).

Etymology: This species is named for the type locality, Woody Island (dendron, Greek, tree).

Diagnosis: The male gonopod sclerite $b$ shape of Atelomastix dendritica is similar to A. flavognatha, but can be distinguished by the lack of bifurcation of sclerite $c$. Sclerite $c$ is curved distally, with a slight submedial concavity. Sclerite $b$ is longer than sclerite $c$, and the distal tip extends beyond the edge of sclerite $c$. 
Description: Male (holotype). Colour: head, collum and antennae dark brown, legs and ozopores goldenbrown legs, prozonites dark blue to dark brown, metazonites light brown in preserved specimens.

Body: ca. $36 \mathrm{~mm}$ long and ca. $2.2 \mathrm{~mm}$ wide at collum. With 55 trunk segments, 99 pairs of legs, last 2 segments without legs.

Head: with ca. 42 ocelli (Fig. 55), arranged in 6 rows (2: 4: 8: 9: 9: 10).

Gonopods: anterior gonopods (Figs. 89-91) lightly sclerotised, 2.40 times longer than broad; sclerite $a$ with swollen base and curved distal hood; upper distal face of sclerite $a$ with 20-21 (n=2) short blunt setae; pseudoflagellum relatively short and visible beneath distal hood; sclerite $b$ relatively large and curved, terminating in an elongate rounded hook beyond top of sclerite $c$, with 11-12 (n=2) setae extending to sub-distal end of sclerite; basal process of sclerite $b$ short and broad, 0.02 times length of main process; sclerite $c$ shorter than sclerite $b$, not bifurcate, ending distally with blunt hook, with 6-8 setae $(\mathrm{n}=2)$ on internal face; sub-basal setae absent where sclerites overlap and group of 14-18 $(\mathrm{n}=2)$ short setae sub-basally on sclerite $c$; posterior gonopods inconspicuous, small, with several small setae on interno-lateral face of each gonopod.

Dimensions (mm): holotype male (paratype male, WAM T74296): length ca. 36 (40), width ca. 2.2 (2.5), $\mathrm{L} / \mathrm{W}=16.5$ (16.6); sclerite $a 1.552 / 0.648$ (1.632/0.691), setae 20 (21); sclerite $b 0.627$ (0.634), basal process of sclerite $b 0.029$ (0.033), setae 11 (12); sclerite $c 1.029$ (1.056), setae $6(8)$.

Female. Unknown.

Distribution and habitat: This species is only known from two males collected from damp leaf litter on Woody Island in the Recherche Archipelago (Fig. 8).

\section{Atelomastix ellenae, sp. nov.}

Figs. 6, 56, 92, 93.

Type material: AUSTRALIA: Western Australia: holotype male, Walpole, reserve next to Rose Road along the Valley of the Giants Road, Walpole-Nornalup National Park, 3456'5”S, 116 55'03"E, hand collected under rotting logs and bark, 29 July 2003, K.L. Edward (WAM T47954). Paratypes: 5 males, 10 females, collected with holotype (WAM T69668); 1 male, Denmark, Hicks Road Reserve, corner of Hicks Road and Lind-

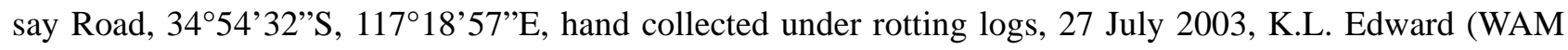
T69664); 4 males, 12 females, Denmark, Mount Hallowell, Sheila Hill Memorial track, 3500'12”S, 117¹9'39'E, hand collected under rotting logs, 24 July 2003, K.L. Edward (WAM T69644).

Other material examined: AUSTRALIA: Western Australia: 1 male, collected with holotype (WAM T69667); 15 males, Denmark, 3459'14'S, 117'20'48”'E, hand collected in karri, marri forest, 8 July 2003, M.S. Harvey, F. Harvey, E. Harvey, K.L. Edward, R. Teale (WAM T69813); 8 males, Walpole, corner of Plain street and South Coast Highway, 34'58'21'’S, 116 42'51'E, hand collected in karri, marri forest, 10 July 2003, K.L. Edward, R. Teale (WAM T69814); 4 males, Denmark, Hicks Road Reserve, corner of Hicks Road and Lindsay Road, 34 54'32'S, 117 $18^{\circ}$ '57'E, hand collected under rotting logs, 27 July 2003, K.L. Edward (WAM T69662, T69663, T69665, T69666); 9 males, Denmark, Mount Hallowell, Sheila Hill Memorial track, 3500'12'S, 117'19'39'E, hand collected under rotting logs, 24 July 2003, K.L. Edward (WAM T69636T69643, T69645); 12 males, Denmark, Harewood forest walk, Scotsdale Road, 3455’34”S, 117¹7’20”E, hand collected under logs, in soil, 27 July 2003, K.L. Edward (WAM T69646-T69652, T69654); 7 males, Denmark, Frankland River, W of bridge along South Coast Highway, 3459'42”S, 116 $48^{\prime} 38^{\prime \prime}$, hand collected under logs, 27 July 2003, K.L. Edward (WAM T69655-T69660); 3 males, 19 females, Walpole, Tree Top Walk, 3458'48'S, 116 53'31'E, hand collected under rotting logs and leaf litter, 29 July 2003, K.L. Edward (WAM T69671); 1 male, 1 female, Kordabup Nature Reserve, 3457'39’'S, 11709'43”E, hand collected under logs and bark, 30 July 2003, K.L. Edward (WAM T69673, T69674); 1 male, 10 females, Den-

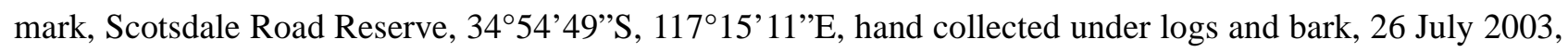


K.L. Edward (WAM T69675); 1 male, Lindsay Road, 3km W of William Road intersection, 3452’22”S, 117 $17^{\prime} 00^{\prime \prime}$, hand collected under logs, 23 July 2003, K.L. Edward (WAM T69681); 1 male, Bow Bridge

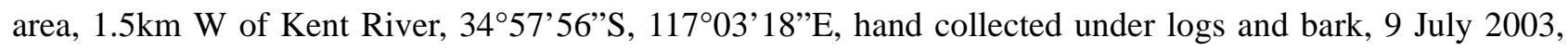
M.S. Harvey, F. Harvey, E. Harvey, K.L. Edward, R. Teale (WAM T69679).

Etymology: The specific epithet is a patronym in honour of Ellen Harvey, who helped collect specimens of this species from southwestern Western Australia.

Diagnosis: Atelomastix ellenae can be distinguished from all other Atelomastix by the distinct morphology of the anterior gonopods. Gonopods of this species exhibit reduced setal numbers and simplification of the sclerite shape. Sclerites $a$ and $c$ are only slightly curved toward the distal end, sclerite $a$ has a small distal hood and a small exposed pseudoflagellum, and sclerite $b$ is relatively straight and thin.

Description: Male (holotype). Colour: head, antennae, gonopods, legs, ozopores and anal valves light yellow-brown, anterior section of collum and anal segment darker; prozonites light blue grey, metazonites golden brown.

Body: ca. $12 \mathrm{~mm}$ long and $1.0 \mathrm{~mm}$ wide at collum. With 39 trunk segments, 67 pairs of legs, last 2 segments without legs.

Head: with ca. 12 ocelli (Fig. 56), arranged in 3 rows (3: 4: 5).

Gonopods: very pale and weakly sclerotised, anterior gonopods (Figs. 92, 93) relatively small and simplified in structure, 2.92 times longer than wide; sclerite $a$ with swollen base that narrows sub-distally, and broadens slightly at distal end; lower surface of distal end rough in texture and 6 short blunt setae on distal face of sclerite $a$; pseudoflagellum extends to distal end of sclerite $a$ where it is entirely exposed; sclerite $b$ thin, short, relatively straight, and tapers to a point, usually with one setae positioned on sub-distal edge (range $0-1, \mathrm{n}=7$ ); basal process of sclerite $b$ very small and round, only 0.09 times length of main process; sclerite $c$ shorter than other sclerites, curves slightly to thin, blunt, rounded tip, swollen medial section exhibits 4-5 long setae situated close to one another $(n=7)$; lacks sub basal setae where sclerites overlap; posterior gonopods inconspicuous, small, and exhibit numerous small setae on interno-lateral face of each gonopod.

Dimensions (mm): holotype male (paratype male, WAM T69664): length ca. 12, width ca. $1.0(\mathrm{~L} / \mathrm{W}=12)$; sclerite $a 0.770 / 0.264(0.824 / 0.352)$, setae $6(11)$; sclerite $b 0.347(0.352)$, basal process of sclerite $b 0.031$ (0.010), setae 1 (1); sclerite $c 0.476$ (0.483), setae 4 (5).

Female. Similar to male, other than sexual characters, and slightly larger.

Distribution and habitat: This species has been recorded from localities between Walpole to Denmark along the south coast of Western Australia (Fig. 6). Specimens were found in a number of different habitats from tall karri (Eucalyptus diversicolor) forests to mixed open jarrah (E. marginata)/marri (Corymbia calophylla) woodlands, and were collected under rotting logs, bark, and soil. This species occurs in sympatry with Atelomastix francesae at a number of locations within its distribution. In some instances individuals of both species have been found under the same rotting log and show evidence of character displacement with $A$. francesae exhibiting a significantly larger body size compared with A. ellenae (Edward, 2003).

\section{Atelomastix flavognatha, sp. nov.}

Figs. 7, 57, 94-97.

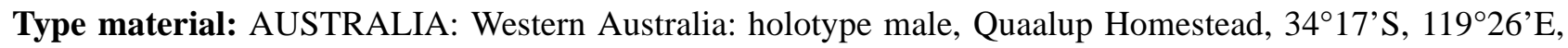
collected at night, 30 May 1994, M.S. Harvey, J.M. Waldock (WAM T73955). Paratypes: 1 male, 1 female, collected with holotype (WAM T47937); 4 males, NE. slope of West Mount Barren, Fitzgerald River National Park, 34 13' S, 119² 26' E, hand collected, 28 May 1994, M.S. Harvey, J.M. Waldock (WAM T47912).

Other material examined: AUSTRALIA: Western Australia: 1 male, 1 female, Mount Maxwell, near summit, Fitzgerald River National Park, 34¹1'48”S, 119¹9'14”'E, hand collected under rocks, 7 June 2007, M.L. 
Moir, M.C. Leng (WAM T80662); 1 female, Mount Maxwell, near summit, Fitzgerald River National Park, 3411'48”S, 119¹9'14'E, hand collected under rocks, 7 June 2007, M.L. Moir, M.C. Leng (WAM T80663);

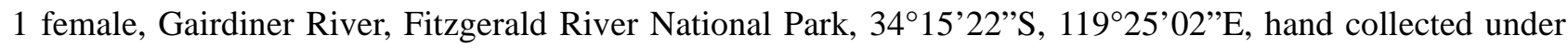
rocks, 6 June 2007, M.L. Moir, M.C. Leng (WAM T80664).

Etymology: This species is named for its yellow mouth region (flavus, Latin, yellow; gnathos, Greek, jaw).

Diagnosis: This species is characterised by distinctive bright yellow mouthparts and legs. Sclerite b of the male gonopods is elongate, curved downwards, with a pointed distal tip, extending past the edge of sclerite $\mathrm{c}$. Sclerite $\mathrm{c}$ is distally bifurcate with lateral and medial processes of similar lengths.

Description: Male (holotype). Colour: legs and mouthparts bright yellow; collum, head, anal segment, ozopores, and antennae dark brown; prozonites pale golden-brown, metazonites pale blue-grey in preserved specimens.

Body: ca. $27 \mathrm{~mm}$ long and ca. $1.8 \mathrm{~mm}$ wide at collum. With 50 trunk segments, 89 pairs of legs, last 2 segments without legs.

Head: with ca. 43 ocelli (Fig. 57), arranged in 6 rows (4: 5: 7: 8: 9: 10).

Gonopods: anterior gonopods (Figs. 94-97) lightly sclerotised, 2.65 times longer than broad; sclerite $a$ with swollen base and broad, curved distal hood; upper distal face of sclerite $a$ with 15-20 (n=2) short blunt setae; pseudoflagellum elongate and visible beneath broadened distal hood; sclerite $b$ relatively long and curved, terminating in an elongate rounded hook, with 11-14 $(\mathrm{n}=2)$ distally serrate extending to sub-distal end of sclerite; basal process of sclerite $b$ broad with blunt tip, 0.30 times length of main process; sclerite $c$ same height as sclerite $b$, shallowly bifurcate, lateral and medial processes of similar length and relatively widely separated, with 3-4 setae $(n=6)$ on internal face; 1 sub-basal setae where sclerites overlap and group of 11-12 $(\mathrm{n}=2)$ short setae sub-basally on sclerite $c$; posterior gonopods inconspicuous, small, with several small setae on interno-lateral face of each gonopod.

Dimensions (mm): holotype male (paratype male, WAM T47937): length ca. 27 (22), width ca. 1.8 (1.6), $\mathrm{L} / \mathrm{W}=15$ (14); sclerite $a 1.258 / 0.474$ (1.197/0.464), setae 20 (15); sclerite $b 0.474$ (0.474), basal process of sclerite $b 0.022$ (0.042), setae 14 (11); sclerite $c 0.864(0.885)$, lateral process of sclerite $c 0.064(0.109)$, medial process of sclerite $c 0.058$ (0.032), setae 3 (4).

Female. Similar to male, other than sexual characters, and slightly larger.

Distribution and habitat: This species can be found at a number of sites in the Fitzgerald River National Park (Fig. 7), where they were mostly found under rocks in mallee heath or Melaleuca, Eucalypt woodlands.

\section{Atelomastix francesae, sp. nov.}

Figs. 5, 58, 98, 99.

Type material: AUSTRALIA: Western Australia: holotype male, Walpole, near Tree Top Walk, 3458'48”S, 116 53'31'E, hand collected under rotting logs and leaf litter, 29 July 2003, K.L. Edward (WAM T47953). Paratypes: 1 male, 5 females, collected with holotype (WAM T69719); 6 males, collected with holotype (WAM T69811); 1 male, Walpole, Peaceful Bay Road, 3458'36”'S, 11655'54”E, hand collected under logs and bark, 26 July 2003, K.L. Edward (WAM T69739).

Other material examined: AUSTRALIA: Western Australia: 15 males, collected with holotype (WAM T69810, T69705-T69718); 1 male, 2 females, Keystone State Forest, Deep River and Meredith Road junction, 3458'59’'S, 116 37'53'E, hand collected under karri bark, 27 May 2004, M.S. Harvey, B.Y. Main (WAM T69744); 4 males, Walpole-Nornalup National Park, Valley of the Giants road, 34'58'50"S, 116 53'22'E, hand collected in karri forest, 9 July 2003, M.S. Harvey, F. Harvey, E. Harvey, K.L. Edward and R.Teale (WAM T69807); 1 female, Walpole-Nornalup National Park, Hilltop Road, near Big Tingle Tree, 34 58'53”'S, 116 46’30”'E, hand collected under karri bark, 13 March 2005, M.S. Harvey, J.M. Waldock, K.L. 
Edward (WAM T69808); 2 males, 1 juvenile, Mount Frankland National Park, 3443'10"S, 116³1'02'E, hand collected from mixed marri, jarrah forest, 10 July 2003, K.L. Edward, R. Teale (WAM T69809); 5 males, Kordabup Nature Reserve, 34 57'39'S, $117^{\circ} 09^{\prime} 43$ 'E, hand collected under logs and bark, 30 July 2003, K.L. Edward (WAM T69687-T69691); 2 females, Kordabup Nature Reserve, 3457'39”S, 11709'43”E, hand collected under logs and bark, 30 July 2003, K.L. Edward (WAM T69692); 11 males, Walpole, Rose Road Reserve, 34 ${ }^{\circ} 56^{\prime} 57^{\prime}$ 'S, $116^{\circ} 55^{\prime} 03^{\prime \prime}$, hand collected under logs and bark, 29 July 2003, K.L. Edward (WAM T69693-T69703); 1 female, Walpole, Rose Road Reserve, 34 56'57'’S, 11655'03'E, hand collected under logs and bark, 29 July 2003, K.L. Edward (WAM T69704); 9 males, Denmark, Scotsdale Road Reserve, cor-

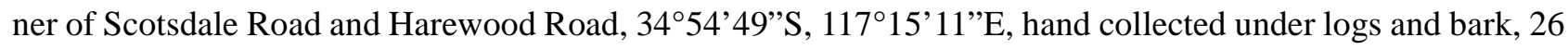
July 2003, K.L. Edward (WAM T69812, T69722-T69729); 2 males, 1 female, Denmark, Scotsdale Road Reserve, 34 $54^{\prime} 49^{\prime \prime}$ 'S, $117^{\circ} 15^{\prime} 11^{\prime \prime} \mathrm{E}$, hand collected under logs and bark, 26 July 2003, K.L. Edward (WAM T69730); 6 females, Denmark, Scotsdale Road Reserve, 3454'49’'S, $117^{\circ} 15^{\prime} 11^{\prime \prime}$, hand collected under logs and bark, 26 July 2003, K.L. Edward (WAM T69731); 9 males, Walpole, Peaceful Bay Road, 3458’36”S, 116 55'54'E, hand collected under logs and bark, 26 July 2003, K.L. Edward (WAM T69732-T69740); 4 females, Walpole, Peaceful Bay Road, 34'58'36'S, 116 55'54'E, hand collected under logs and bark, 26 July 2003, K.L. Edward (WAM T69741); 1 male, Walpole-Nornalup National Park, East of town along South

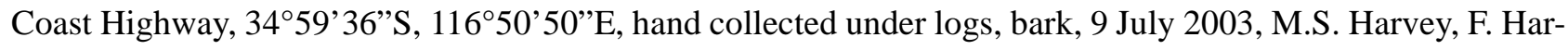
vey, E. Harvey, K.L. Edward, R. Teale (WAM T69745); 6 males, Walpole-Nornalup National Park, "Tingle Tree", 3500'S, $116^{\circ} 38^{\prime}$ E, 2 July 1980, S.B.S. Peck (WAM T47938).

Etymology: The specific epithet is a patronym in honour of Frances Harvey, who helped collect specimens of Atelomastix in Walpole and Denmark.

Diagnosis: Atelomastix francesae is similar to A. albanyensis, but can be distinguished by the shape of sclerites $b$ and $c$. Sclerite $b$ is blunt, broadly shaped, and does not taper or curve to a point distally. Sclerite $c$, which is deeply bifurcated, does not have a curved lateral process, and the medial process is much more elongated, exhibiting a number of setae medially rather than on the distal edge.

Description: Male (holotype). Colour: Dorsal part of head dark brown; rest of head, mouth parts, antennae, gonopod, ozopores and legs light golden-brown; prozonites pale yellow brown, metazonites dark to bluegrey.

Body: ca. $16 \mathrm{~mm}$ long and ca. $1.4 \mathrm{~mm}$ wide at collum. With 39 trunk segments, 67 pairs of legs, last 2 segments without legs.

Head: with ca. 24 ocelli (Fig. 58), arranged in 5 rows (2: 4: 5: 6: 7).

Gonopods: anterior gonopods (Figs. 98, 99) complex, relatively large, compact, broad, and heavily scleritised, 2.19 times longer than broad; sclerite $a$ with swollen base and broad, curved distal hood; upper distal face of sclerite $a$ with 22 short blunt setae; pseudoflagellum short, broad, and partially concealed within broadened distal hood; sclerite $b$ broad and slightly curved distally, with 2-7 setae on distal edge $(\mathrm{n}=15)$; basal process of sclerite $b$ small with rounded tip, 0.09 times the length of the main process; sclerite $c$ deeply bifurcate, lateral process slightly curved forming a blunt tip, medial process triangular in shape with 3-8 setae $(\mathrm{n}=15)$ spread over middle of process; one small setae present at sub basal end of sclerite, and group of 9 very short setae present basally; posterior gonopods inconspicuous, small, with several small setae on interno-lateral face of each gonopod.

Dimensions (mm): holotype male (paratype male, WAM T69739): length ca. 16, width ca. 1.4 (L/ $\mathrm{W}=11.1)$; sclerite $a 0.997 / 0.456(0.992 / 0.454)$, setae 22 ; sclerite $b 0.450(0.447)$, basal process $0.039(0.023)$, setae 5 subdistal +1 distal (4 subdistal); sclerite $c 0.749(0.760)$, lateral process of sclerite $c 0.272(0.269)$, medial process of sclerite $c 0.225(0.237)$, setae 7 (7).

Female. Similar to male, other than sexual characters, and slightly larger.

Distribution and habitat: Atelomastix francesae has been recorded from several localities between Walpole to Denmark along the south coast of Western Australia (Fig. 5). Specimens can be found under and 
within rotting logs, moist leaf litter, and in the soil under rocks in a variety of different habitats, including tall karri (Eucalyptus diversicolor) and tingle (E. jacksonii) forests, open jarrah (E. marginata) / marri (Corymbia calophylla) woodlands, and granite outcrops. This species has been found to exist in sympatry with A. ellenae at a number of locations within its distribution.

\section{Atelomastix gibsoni, sp. nov.}

Figs. 7, 59, 100, 101.

Type material: AUSTRALIA: Western Australia: holotype male, Ravensthorpe Ranges South, 235 m elevation, 3338'02"S, $120^{\circ} 10^{\prime} 55^{\prime}$ 'E, hand collected under rocks, 15 May 2007, M.C. Leng, M.L. Moir, S. Comer (WAM T83220). Paratypes: 3 males, 5 females, collected with holotype (WAM T80858); 4 males, 3 females, Mount Chester, Ravensthorpe Ranges South, 319 m elevation, 3336'18”S, 12008'34'E, hand collected under rocks, 10 September 2007, M.C. Leng (WAM T81295); 4 males, 8 females, Ravensthorpe Ranges

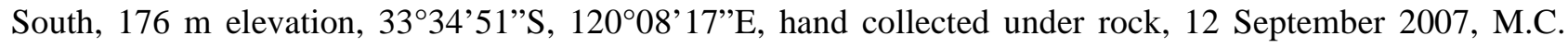
Leng, J. Newell (WAM T81299); 1 male, 6 females, Mount Desmond Lookout, Ravensthorpe Ranges South, 336 m elevation, $33^{\circ} 36^{\prime} 51^{\prime \prime}$ S, $120^{\circ} 09^{\prime} 08^{\prime \prime}$, hand collected in leaf litter and under rock, 13 September 2007, M.C. Leng, J. Newell (WAM T81292).

Other material examined: AUSTRALIA: Western Australia: 1 female, collected with holotype (WAM T80857); 4 males, 3 females, 14 juveniles, Mount Chester, Ravensthorpe Ranges South, $319 \mathrm{~m}$ elevation, 3336'18'S, 12008'34'E, tullgren funnel leaf litter extraction, 24 May 2007, M.C. Leng, M.L. Moir (WAM T80994); 24 males, 24 females, Mount Chester, Ravensthorpe Ranges South, 319 m elevation, 33³6'18”S, $120^{\circ} 08^{\prime} 34$ 'E, hand collected under rocks, 10 September 2007, M.C. Leng (WAM T80988); 10 males, 7 females, Mount Desmond Lookout, Ravensthorpe Ranges South, 336 m elevation, 33³6'51'S, 12009'08'E, hand collected in leaf litter and under rock, 16 May 2007, M.C. Leng, M.L. Moir (WAM T80863, T80862); 10 males, 26 females, Mount Desmond Lookout, Ravensthorpe Ranges South, 336 m elevation, 3336'51'S, $120^{\circ} 09^{\prime} 08^{\prime \prime}$, tullgren funnel leaf litter extraction, 16 May 2007, M.C. Leng, M.L. Moir (WAM T80866); 13

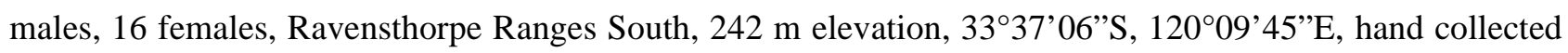
in leaf litter, under rotting logs and bark, 15 May 2007, M.C. Leng, M.L. Moir (WAM T80851-T80852); 2 males, 10 females, Ravensthorpe Ranges South, 253 m elevation, 3336'56”S, 12009'43'E, hand collected in leaf litter and under bark, 16 May 2007, M.C. Leng, M.L. Moir (WAM T80859-T80860); 17 males, 12 females, Ravensthorpe Ranges South, 155 m elevation, 33'34'34”S, 120'08'29'E, hand collected in leaf litter and under rock, 19 May 2007, M.C. Leng, M.L. Moir (WAM T80913-T80914); 12 males, 7 females, Ravensthorpe Ranges South, 218 m elevation, 3338'19'S, 120'11'16”'E, hand collected in leaf litter and under rock, 28 May 2007, M.C. Leng, M.L. Moir (WAM T88779-T88781, 81013); 8 males, 13 females, Ravenst-

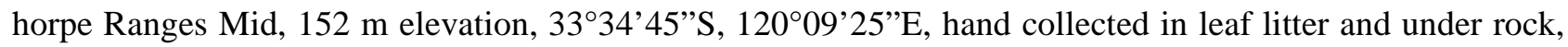
24 May 2007, M.C. Leng, M.L. Moir (WAM T81004); 28 males, 39 females, Ravensthorpe Ranges Mid, 201 m elevation, 33³4'59'S, 12007'36”'E, hand collected in leaf litter and under rock, 28 May 2007, M.C. Leng, M.L. Moir (WAM T81027-81028); 41 males, 43 females, Ravensthorpe Ranges North, 279 m elevation, 33 32'35'S, 120 06'17'E, hand collected in leaf litter and under rock, 21 May 2007, M.C. Leng, M.L. Moir (WAM T80945-T80946); 30 males, 16 females, Archer Drive Lookout, Ravensthorpe Ranges North, $383 \mathrm{~m}$

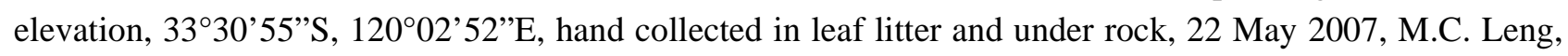
M.L. Moir (WAM T80962-T80963); 3 males, 7 females, Ravensthorpe Ranges North, 379 m elevation, 3331'13”S, 12003'34'E, hand collected under rock, 23 May 2007, M.C. Leng, M.L. Moir (WAM T80976); 6 males, 20 females, Ravensthorpe Ranges North, 314 m elevation, 3331'48”S, 12004'20”E, hand collected in leaf litter and under rocks, 23 May 2007, M.C. Leng, M.L. Moir (WAM T80978); 1 male, Ravensthorpe

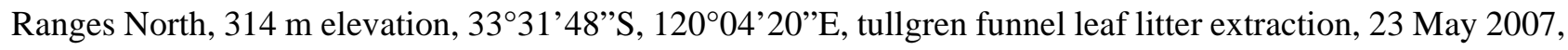
M.C. Leng, M.L. Moir (WAM T80981). 
Etymology: This species is named for Neil Gibson, who facilitated a research project in the Ravensthorpe Range in which many Atelomastix specimens were collected.

Diagnosis: Atelomastix gibsoni differs from all other species of the genus as the male gonopod sclerite $b$ is greatly enlarged distally forming a large wedge-shape that extends to overlap the broad distal hood of sclerite $a$. Sclerite $c$ is reduced in size, broad sub-distally and tapering slightly to a broad slightly curved tip, with a slight concavity on the externo-lateral surface where setae are situated.

Description: Male (holotype). Colour: generally chocolate-brown, legs, anal segment, and antennae light brown, mouthparts slightly lighter; prozonites chocolate brown, metazonites chocolate brown to light fawn in preserved specimens.

Body: ca. $24 \mathrm{~mm}$ long and ca. $1.8 \mathrm{~mm}$ wide at collum. With 56 trunk segments, 101 pairs of legs, last 2 segments without legs.

Head: with ca. 34 ocelli (Fig. 59), arranged in 6 rows (2: 7: 7: 7: 6: 5).

Gonopods: anterior gonopods (Figs. 100, 101) with medium sclerotisation, 2.3 times longer than broad; sclerite $a$ with swollen base that forms broad, curved distal hood that overlaps and extends beyond tip of sclerite $b$; upper distal face of sclerite $a$ with 24-30 (n=2) short blunt setae; pseudoflagellum relatively short and partially visible beneath broad distal hood; sclerite $b$ very broad and enlarged distally, forming a wedge shape, with 4-8 (n=2) short setae; basal process of sclerite $b$ very short, 0.01 times length of main process; sclerite $c$ shorter than sclerite $b$, slightly concave on externo-lateral surface, slightly tapering to blunt rounded tip, with 1 seta on interno-lateral side of sclerite $c$ and 5 setae within externo-lateral concavity of sclerite $c(\mathrm{n}=2)$; subbasal setae absent where sclerites overlap and group of 10-12 $(\mathrm{n}=2)$ short setae sub-basally on sclerite $c$; posterior gonopods inconspicuous, small, with several small setae on interno-lateral face of each gonopod.

Dimensions (mm): holotype male (paratype male, WAM T80858): length ca. 24 , width ca. $1.5, \mathrm{~L} / \mathrm{W}=16.0$; sclerite $a 0.944 / 0.419(0.880 / 0.416)$, setae 24 (30); sclerite $b 0.320(0.294)$, basal process of sclerite $b 0.01$ (0.01), setae 4 (8); sclerite $c 0.582(0.563)$, setae $1+5(1+5)$.

Female. Similar to male, other than sexual characters, and slightly larger.

Distribution and habitat: This species is known from a number of sites in the Ravensthorpe Ranges (Fig. 7) characterised by Hakea, Banksia, Eucalyptus woodlands and mallee heath and was found amongst leaf litter and under rotting logs, bark and rocks.

\section{Atelomastix grandis, sp. nov.}

Figs. 9, 60, 102, 103.

Type material: AUSTRALIA: Western Australia: holotype male, Mount Le Grand, Le Grand National Park, 33'59'25"S, 122 07'35”'E, hand collected in soil, 27 December 2006, M.L. Moir, K.E.C. Brennan (WAM T83221). Paratypes: 5 males, 4 females, collected with holotype (WAM T78761); 3 males, 13 females, Mount Le Grand, Le Grand National Park, summit, 3359'41”S, $122^{\circ} 07^{\prime} 48^{\prime \prime}$, hand collected under granite rocks, 4 June 2007, M.L. Moir, M.C. Leng (WAM T80740, T80741); 1 female collected with holotype (WAM T78760).

Etymology: This species is named both for its distribution within Le Grand National Park and the great size of the male gonopods (grandis, Latin: large, great, noble, etc.).

Diagnosis: Atelomastix grandis, although not the biggest millipede in length or number of segments, has the longest gonopod of all Atelomastix species (total gonopod length=1.78-1.79 mm). It differs from all other species by several distinct gonopod morphological differences. Sclerite $c$ is relatively straight, broad, indented sub-distally with a broad rounded distal tip. Sclerite $b$ has a pointed narrow distal tip and does not extend to sclerite $c$. Sclerite $a$ has a short but deep distal hood, entirely exposing an elongate pseudoflagellum. 
Description: Male (holotype). Colour: generally chocolate-brown; legs, antennae, mouthparts, and head golden brown; well defined bands between segments; prozonites dark chocolate brown, metazonites brown to lighter brown in preserved specimens.

Body: ca. $48 \mathrm{~mm}$ long and ca. $2.9 \mathrm{~mm}$ wide at collum. With 54 trunk segments, 97 pairs of legs, last 2 segments without legs.

Head: with ca. 37 ocelli (Fig. 60), arranged in 5 rows (4: 7: 8: 9:9).

Gonopods: anterior gonopods (Figs. 102, 103) heavily sclerotised, 2.5 times longer than broad; sclerite $a$ with swollen base that forms short but deep curved distal hood; upper distal face of sclerite $a$ with 21-22 $(n=2)$ short blunt setae; pseudoflagellum elongate and entirely visible beneath distal hood; sclerite $b$ narrowed and curved subdistally, with short, narrow rounded distal tip, 8-14 $(n=2)$ short setae present on sub-distal edge; basal process of sclerite $b$ rounded, 0.06 times length of main process; sclerite $c$ relatively long and broad, indented sub-distally, with broad rounded distal tip, 7-10 setae $(\mathrm{n}=2)$ present near indentation; subbasal setae not visible where sclerites overlap and group of $15(\mathrm{n}=2)$ short setae sub-basally on sclerite $c$; posterior gonopods inconspicuous, small, with several small setae on interno-lateral face of each gonopod.

Dimensions (mm): holotype male (paratype male, WAM T78761): length ca. 48, width ca. 2.9, $\mathrm{L} / \mathrm{W}=16.6$; sclerite $a 1.792 / 0.712(1.784 / 0.680)$, setae $22(21)$; sclerite $b 0.680(0.680)$, basal process of sclerite $b 0.038$ (0.045), setae 8 (14); sclerite $c 1.360$ (1.280), setae 7 (10).

Female. Similar to male, other than sexual characters, and slightly larger.

Distribution and habitat: Atelomastix grandis is only known from under rocks or in soil on granite outcrops and Agonis heath of Mount Le Grand in the Le Grand National Park (Fig. 9). It occurs in sympatry with A. brennani near the summit of Mount Le Grand and is larger than this species, thus possibly showing evidence of character displacement.

\section{Atelomastix julianneae, sp. nov.}

Figs. 5, 61, 104, 105.

Type material: AUSTRALIA: Western Australia: holotype male, south end of Millinup Pass, Porongurup Range National Park, 3441'43's, 11753'51'E, hand collected under rotting logs, 30 March 1996, M.S. Harvey, J.M. Waldock, B.Y. Main (WAM T69805). Paratype: 1 male, collected with holotype (WAM T71601).

Etymology: The specific epithet is a patronym in honour of Julianne Waldock who collected the holotype and numerous other species of Atelomastix in southwestern Western Australia.

Diagnosis: Atelomastix julianneae can be distinguished from other Atelomastix species as it is characterised by a very large, broad, and distally rounded sclerite $b$. Sclerite $\mathrm{c}$ is not bifurcate, is relatively broad, subdistally narrowed and curved to a rounded tip, with 12 setae positioned on a wide section of the sclerite, partially hidden by sclerite $b$. This species also has 7 eye rows. Live specimens of A. julianneae have a very striking colour pattern of black or dark brown segments with bright yellow-orange bands, similar to A. tigrina.

Description: Male (holotype). Colour: live specimens dark brown-black with yellow-orange bands between segments; head, collum, anal segment dark brown, rest of body yellow-orange, prozonites light yellow-brown, metazonites dark brown to yellow in preserved specimens.

Body: ca. $36 \mathrm{~mm}$ long and ca. $1.8 \mathrm{~mm}$ wide at collum. With 56 trunk segments, 101 pairs of legs, last 2 segments without legs.

Head: with ca. 39 ocelli (Fig. 61), arranged in 7 rows (1:3:5: 6: 7: 8:9).

Gonopods: anterior gonopods (Figs. 104, 105) very large, heavily sclerotised and complex in structure, 2.28 times longer than broad; sclerite $a$ with swollen base and broad, curved distal hood; upper distal face of sclerite $a$ with 18-21 (n=2) short blunt setae; pseudoflagellum short, broad, and entirely visible on externolateral side of gonopod but not visible on interno-lateral side, where it is concealed within distal hood; sclerite 
$b$ broad, slightly curved inwards, with 5-7 $(\mathrm{n}=2)$ long setae that curve to distal end of sclerite; basal process of sclerite $b$ long, triangular, tapering to blunt tip, 0.26 times length of main process; sclerite $c$ not bifurcate, broad, with 12 setae $(n=2)$ on broad internal face; with very long sub-basal setae where sclerites overlap and group of 11-15 $(\mathrm{n}=2)$ short setae sub-basally on sclerite $c$; posterior gonopods inconspicuous, small, with several small setae on interno-lateral face of each gonopod.

Dimensions (mm): holotype male (paratype male, WAM T71601): length ca. 36 (44), width ca. 1.8 (1.8); $\mathrm{L} / \mathrm{W}=19.6$ (24.1); sclerite $a 1.130 / 0.496$ (1.026/0.461), setae 21 (18); sclerite $b 0.502$ (0.493), basal process of sclerite $b 0.130$ (0.137), setae 7 (5); sclerite $c 0.899$ (0.808), setae 12 (12).

Female. Unknown.

Distribution and habitat: This species has only been recorded from the Porongurup Range National Park (Fig. 5) and specimens were collected from under rotting eucalypt logs.

\section{Atelomastix lengae, sp. nov.}

Figs. 8, 62, 106, 107.

Type material: AUSTRALIA: Western Australia: holotype male, Eyre Range, Fitzgerald River National

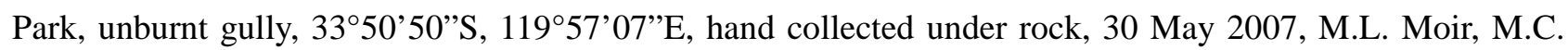
Leng (WAM T80799).

Other material examined: AUSTRALIA: Western Australia: 1 female, Eyre Range, Fitzgerald River National Park, unburnt rock outcrop, 3351'50”S, 11957’32”E, hand collected under rock, 30 May 2007, M.L. Moir, M.C. Leng (WAM T80800).

Etymology: The specific epithet is a patronym in honour of Frances Leng who collected the holotype and numerous other species of Atelomastix in southwestern Australia.

Diagnosis: Atelomastix lengae differs from all other species as the male gonopod sclerite $c$ is barely distally bifurcate, and is generally straight and slightly broadened distally. It has a broad sclerite $b$ that does not extend to sclerite $c$ and tapers gently to a broad tip distally.

Description: Male (holotype). Colour: generally dark brown; legs, antennae, mouthparts, lighter brown with distinctly light bands; prozonites dark brown; metazonites dark brown to very pale in preserved specimens.

Body: ca. $42 \mathrm{~mm}$ long and ca. $2.4 \mathrm{~mm}$ wide at collum. With 67 trunk segments, 123 pairs of legs, last 2 segments without legs.

Head: with ca. 52 ocelli (Fig. 62), arranged in 7 rows (4: 5: 6: 7: 9: 10: 11).

Gonopods: anterior gonopods (Figs. 106, 107) with light to medium sclerotisation, 2.3 times longer than broad; sclerite $a$ with swollen base that forms broad, curved distal hood; upper distal face of sclerite $a$ with 52 short blunt setae; pseudoflagellum relatively short and partially visible beneath broad distal hood; sclerite $b$ broad, tapers gently to a broad distal tip that does not extend to sclerite $c$, with 7 short setae; basal process of sclerite $b$ very short, 0.01 times length of main process; sclerite $c$ about same height as sclerite $b$, slightly concave on internal surface, with slight indent sub-distally and slightly broadened distally to a very shallow bifurcated tip, with 4 setae; sub-basal setae not visible where sclerites overlap and group of 11 short setae subbasally on sclerite $c$; anterior gonopods inconspicuous, small, with several small setae on interno-lateral face of each gonopod.

Dimensions (mm): holotype male: length ca. 42 , width ca. 2.4 , L/W=17.5; sclerite $a 1.44 / 0.634$, setae 52; sclerite $b 0.506$, basal process of sclerite $b 0.014$, setae 7 ; sclerite $c 1.024$, setae 4 .

Female. Similar to male, other than sexual characters, and slightly larger.

Distribution and habitat: This species is only known from one male and one female from an unburnt gully in the Eyre range, Fitzgerald River National Park (Fig. 9). These two specimens were found under rocks. 
Atelomastix longbottomi, sp. nov.

Figs. 8, 63, 108, 109.

Type material: AUSTRALIA: Western Australia: holotype male, southern side of Mount Belches, Duke of Orleans Bay, 3356'36”S, 122 33'42”'E, hand collected under granite rocks, 2 June 2007, M.L. Moir, A. Longbottom (WAM T82780). Paratypes: 2 males, collected with holotype (WAM T82781, T82782); 3 males, 8 females, collected with holotype (WAM T80739).

Etymology: The specific epithet is a patronym in honour of Allan Longbottom who collected the holotype and numerous other species of Atelomastix in southwestern Western Australia.

Diagnosis: Atelomastix longbottomi is similar to A. psittacina and A. culleni but differs in the shape of sclerites $a$ and $b$. The shape of the distal hood of sclerite $a$ does not curve around to touch the tip of sclerite $b$ and obscure the pseudoflagellum as in A. psittacina and A. culleni. Sclerite $b$ is shorter, does not extend to sclerite $a$, and does not resemble a parrot beak with only a slightly curved distal tip. Sclerite $c$ is not bifurcated, but is relatively broad, straight and only slightly tapering.

Description: Male (holotype). Colour: head, collum and anal segment dark brown, antennae, ozopores and legs fawn, prozonites fawn, metazonites fawn to darker brown in preserved specimens.

Body: ca. $21 \mathrm{~mm}$ long and ca. $1.5 \mathrm{~mm}$ wide at collum. With 44 trunk segments, 75 pairs of legs, last 3 segments without legs.

Head: with ca. 23 ocelli (Fig. 63), arranged in 5 rows (2: 4: 5: 6: 6).

Gonopods: anterior gonopods (Figs. 108, 109) lightly sclerotised, 2.4 times longer than broad; sclerite $a$ with swollen base that forms curved distal hood; upper distal face of sclerite $a$ with 10-16 (n=2) short blunt setae; pseudoflagellum relatively short and visible beneath distal hood; sclerite $b$ broad, slightly curved distally, tapering to blunt tip, distal edge weakly serrate, with 7-8 $(n=2)$ short setae; basal process of sclerite $b$ short and broad, 0.03 times length of main process; sclerite $c$ slightly shorter than sclerite $b$, not bifurcate, broad basally, tapering slightly to blunt tip, with 5 medial setae; long sub-basal setae present where sclerites overlap and group of 5-8 (n=2) short setae sub-basally on sclerite $c$; posterior gonopods inconspicuous, small, with several small setae on interno-lateral face of each gonopod.

Dimensions (mm): holotype male (paratype male, WAM T82781): length ca. 21, width ca. 1.5, L/W=14; sclerite $a 0.912 / 0.384(1.00 / 0.454)$, setae $16(10)$; sclerite $b 0.294(0.336)$, basal process of sclerite $b 0.011$ (0.011), setae 8 (7); sclerite $c 0.621$ (0.672), setae 5 (5).

Female. Similar to male, other than sexual characters, and slightly larger.

Distribution and habitat: Atelomastix longbottomi is only known from the southern side of Mount Belches on Duke of Orleans Bay (Fig. 8). A total of six males and eight females were found under granite rocks, in sympatry with $A$. melindae.

\section{Atelomastix mainae, sp. nov.}

Figs. 5, 64, 110, 111.

Atelomastix albanyensis Attems 1911: 194-195 (in part).

Type material: AUSTRALIA: Western Australia: holotype male, Albany, Mount Clarence, $35^{\circ} 01^{\prime 2} 24^{\prime \prime}$, $117^{\circ} 53^{\prime} 53^{\prime}$ 'E, hand collected under rotting logs and bark, 23 July 2003, K.L. Edward (WAM T47955). Paratypes: 9 males, 21 females, collected with holotype (WAM T69596); 1 male, collected with holotype (WAM T69589).

Other material examined: AUSTRALIA: Western Australia: 6 males, collected with holotype (WAM T69587, T69588, T69590-T69593); 10 males, Albany, Mount Melville, 3500'56”S, 11752’05”E, hand col- 
lected under rotting logs and bark, 23 July 2003, K.L. Edward (WAM T69597-T69601, T69629-T69633); 17

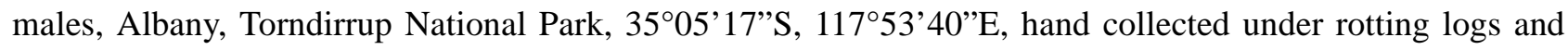
bark, 23 July 2003, K.L. Edward (WAM T69585); 9 males, Albany, Torndirrup National Park, 3505’17'S, $117^{\circ} 53^{\prime} 40^{\prime \prime}$, hand collected under rotting logs and bark, 23 July 2003, K.L. Edward (WAM T69575T69578, T69580-T69584); 1 male, Albany, Hamburger südwest-australischen Forschungsreise, Station 165, 35 $01^{\prime}$ 'S, $117^{\circ} 53^{\prime} \mathrm{E}, 13$ August 1905, W. Michaelsen, R. Hartmeyer (WAM 13/7145; paralectotype of $A$. albanyensis); 7 males, Elleker, Marbelup Nature Reserve, 3459'11'S, 117'43'38'E, hand collected under rotting logs, 26 July 2003, K.L. Edward (WAM T69551-T69554, T69742, T69743, T69788); 3 males, Tor-

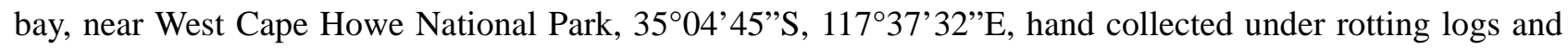
bark of live karri trees, 25 July 2003, K.L. Edward, B.Y. Main (WAM T69564); 7 males, Torbay, near West

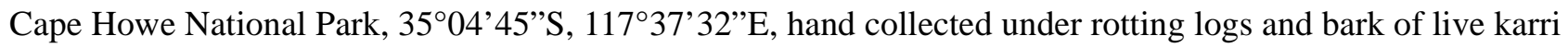
trees, 25 July 2003, K.L. Edward, B.Y. Main (WAM T69558-T69563, T69565); 6 males, Torbay, near West Cape Howe National Park, 3504'39'S, 117'37’21'E, hand collected under rotting logs, 25 July 2003, K.L. Edward, B.Y. Main (WAM T69566-T69571); 1 male, Torbay Head, Lot 40, west side of granite, 3504'S, $117^{\circ} 37^{\prime}$ E, wet pitfall trap, 20 April-14 May 1987, B.Y. Main (WAM T69574).

Etymology: The specific epithet is a patronym in honour of Barbara York Main who has made significant contributions to our knowledge of historical biogeography in southwestern Western Australia.

Diagnosis: Atelomastix mainae is similar to A. attemsi, but differs in the shape and size of the lateral and medial processes of sclerite $c$. In this species the lateral and medial processes of sclerite $c$ are asymmetrical with the lateral process longer and thinner than the medial process, whereas in A. attemsi the lateral process is broader and similar in length to the medial process. The basal process of sclerite $b$ also differs in shape. Atelomastix mainae has a broad triangular process with a rounded tip 0.14 times the size of the main process, whereas $A$. attemsi has a longer, thinner process, 0.23 times the size of the main process.

Description: Male (holotype). Colour: Collum and anal segment dark brown; head, mouth parts, antennae, gonopod, ozopores and legs light golden-brown; prozonites blue-grey, metazonites brown to blue-grey. Body: ca. $17 \mathrm{~mm}$ long and ca. $1.4 \mathrm{~mm}$ wide at collum. With 38 trunk segments, 65 pairs of legs, last 2 segments without legs.

Head: with ca. 29 ocelli (Fig. 64), arranged in 4 rows (2: 5: 5: 7).

Gonopods: anterior gonopods (Figs. 110, 111) small and complex in structure, 2.59 times longer than broad; sclerite $a$ with swollen base and broad, curved distal hood; upper distal face of sclerite $a$ with 18 short blunt setae; pseudoflagellum short, broad, and partially concealed within broadened distal hood; sclerite $b$ elongate, curving to rounded hook at distal end, with 2-7 setae on subdistal edge $(n=3)$; basal process of sclerite $b$ short, triangular, with rounded end, 0.14 times length of main process; sclerite $c$ shallowly bifurcate, same height as sclerite $b$, lateral and medial process asymmetrical, but both tapering to a blunt rounded tip, with 3-4 setae $(n=3)$ positioned below division of lateral and medial processes; one setae present at sub basal end of sclerite $c$, where sclerites overlap; posterior gonopods inconspicuous, small, with several small setae on interno-lateral face of each gonopod.

Dimensions (mm): holotype male (paratype male, WAM T69589): length ca. 17, width ca. 1.3 (L/ $\mathrm{W}=13.1)$; sclerite $a 0.928 / 0.358(0.855 / 0.352)$, setae 18 ; sclerite $b 0.410(0.395)$, basal process of sclerite $b$ 0.057 (0.053), setae 7 (2); sclerite $c 0.590(0.621)$, lateral process of sclerite $c 0.137(0.131)$, medial process of sclerite $c 0.074$ (0.086), setae 3 (4).

Female. Similar to male, other than sexual characters, and slightly larger.

Distribution and habitat: This species has a coastal distribution from Torbay to Albany along the south coast of Western Australia (Fig. 5). Specimens can be found in mixed karri (Eucalyptus diversicolor) forest, mixed jarrah (E. marginata), blackbutt (E. patens) and marri (Corymbia calophylla) open woodland, and on granite outcrops. Collections of this species were from under rotting logs, under bark of fallen logs, under bark of live karri (Eucalyptus diversicolor) trees, and under leaf litter. 
Atelomastix melindae, sp. nov.

Figs. 7, 65, 112, 113.

Type material: AUSTRALIA: Western Australia: holotype male, Mount Arid, Cape Arid National Park, south side near summit, 335' $45^{\prime \prime} \mathrm{S}, 123^{\circ} 13^{\prime} 01^{\prime \prime} \mathrm{E}$, hand collected under granite rocks, 5 June 2007, M.L. Moir, M.C. Leng (WAM T83248). Paratypes: 2 males, 2 females, collected with holotype (WAM T83223).

Other material examined: AUSTRALIA: Western Australia: 1 male, collected with holotype (WAM T82885); 2 males, 5 females, 8 juveniles collected with holotype (WAM T80706); 2 males, 11 females, collected with holotype (WAM T80705); 1 male, Mount Belches, near summit, Duke of Orleans Bay,

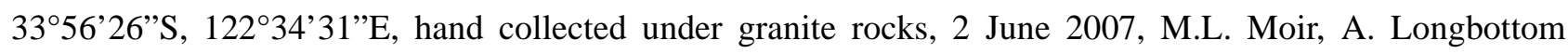
(WAM T82884); 7 males, 5 females, Mount Belches, southern side, Duke of Orleans Bay, 3356'36”S, $122^{\circ} 33^{\prime} 42^{\prime \prime} \mathrm{E}$, hand collected under granite rocks, 2 June 2007, M.L. Moir, A. Longbottom (WAM T80693).

Etymology: The specific epithet is a patronym in honour of Melinda Moir who collected the holotype and numerous other species of Atelomastix in southwestern Western Australia.

Diagnosis: The male gonopod morphology of Atelomastix melindae is similar to that of A. anancita, A. flavognatha and A. psittacina as it has a distally bifurcated sclerite $c$, similar sclerite $b$ morphology, and the tip of sclerite $b$ extends between the bifurcation and beyond the edge of sclerite $c$. It can be distinguished from these species by a shallow, symmetrical to slightly asymmetrical distal bifurcation on the distal tip of sclerite $c$. Further, the distal tip of sclerite $c$ is quite variable but generally widens distally to form an angular tip with two sharp, pointed edges either side of a shallow bifurcation, compared with the rounded, non bifurcated tip of A. psittacina. The distal end of sclerite $b$ is quite variable but relatively shorter, broader and less curved compared with A. flavognatha.

Description: Male (holotype). Colour: legs, gonopod, head, antennae golden brown; segments generally mottled chocolate brown; prozonites chocolate brown, metazonites chocolate brown to yellow in preserved specimens.

Body: ca. $35 \mathrm{~mm}$ long and ca. $2.0 \mathrm{~mm}$ wide at collum. With 52 trunk segments, 93 pairs of legs, last 2 segments without legs.

Head: with ca. 49 ocelli (Fig. 65), arranged in 7 rows (3: 5: 7: 9: 10: 8: 7).

Gonopods: anterior gonopods (Figs. 112, 113) of medium to heavy sclerotisation, 2.1-2.5 (n=2) times longer than broad; sclerite $a$ with swollen base that forms broad, curved distal hood; upper distal face of sclerite $a$ with 19-23 ( $\mathrm{n}=2)$ short blunt setae; pseudoflagellum relatively short and partially visible beneath distal hood; sclerite $b$ curved sub-distally, tapering to blunt distal tip, generally extending between sclerite $c$ bifurcation and beyond edge of sclerite $c$, with 13-20 $(\mathrm{n}=2)$ sub-distal setae; basal process of sclerite $b$ short, 0.07 times length of main process; sclerite $c$ shorter than sclerite $b$, shallowly bifurcate, lateral and medial process short and of variable symmetry, ending in angular pointed edges either side of bifurcation, with 5 setae $(n=2)$ below bifurcation; sub-basal setae absent where sclerites overlap and group of 10-12 ( $\mathrm{n}=2)$ short setae sub-basally on sclerite $c$; posterior gonopods inconspicuous, small, with several small setae on interno-lateral face of each gonopod.

Dimensions (mm): holotype male (paratype male, WAM T80673): length ca. 35, width ca. 2.0, L/W=17.2; sclerite $a 1.312 / 0.627(1.568 / 0.627)$, setae 19 (23); sclerite $b 0.474(0.454)$, basal process of sclerite $b 0.033$ (0.019), setae 20 (13); sclerite $c 0.880(0.928)$, lateral process $0.040(0.045)$, medial process $0.048(0.058)$, setae $5(5)$.

Female. Similar to male, other than sexual characters, and slightly larger.

Distribution and habitat: Atelomastix melindae is known from the rocky outcrops and heath near the summit of Mount Arid in the Cape Arid National Park, and granite outcrop and eucalypt forest of Mount Belches, near the Duke of Orleans Bay (Fig. 7). Specimens were collected under granite rocks and have been found in sympatry with A. longbottomi at one locality where both species were under the same rocks. 
Type material: AUSTRALIA: Western Australia: holotype male, south face of Pyungoorup Peak, Stirling

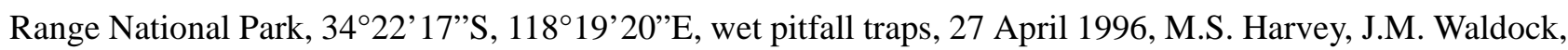
B.Y. Main (WAM T72777). Paratypes: 3 males, collected with holotype (WAM T69804); 3 males, 6 females, north end of South Isongerup Track, Stirling Range National Park, 34 22’24”'S, 118 16'58”E, hand collection under logs, 8 April 2004, M.S. Harvey, J.M. Waldock, K. Edward, C. Poustie (WAM T69441, T72805).

Other material examined: AUSTRALIA: Western Australia: Stirling Range National Park: 1 male, south face of Pyungoorup Peak, 4²2’17’S, 118¹9’20”E, wet pitfall traps, 4 August 1996, M.S. Harvey, J.M. Waldock, B.Y. Main (WAM T69806); 2 males, north end of South Isongerup Track, 34²2'25'S, 118 16'59'E, hand collected from creek bank, 16 March 2005, M.S. Harvey, J.M. Waldock, K. Edward (WAM T69817); 1 male, 8 females, Stirling Range National Park, base of Pyongurup Peak, 34²2’01"S, $118^{\circ} 19^{\prime} 48^{\prime \prime E}, 5$ August 2008, from ground, litter, M.G. Rix, M.S. Harvey (WAM T54251); 1 male, SE. of Coyanarup Peak, 34²3'34'S, 118 16'04'E, hand collected in creek bed leaf litter, 7 March 2005, M.S. Harvey, J.M. Waldock, K. Edward, C. Poustie (WAM T72806); 2 males, western end of Ellen track, 34 23'04'S, 118 17'17’'E, wet pitfall traps, 30 April 1996, M.S. Harvey, J.M. Waldock, B.Y. Main (WAM T47931, T47932); 3 males, 5 females, western end of Ellen track, 34²2'54”'S, 118 17'25”'E, hand collected under logs, 8 April 2004, M.S. Harvey, J.M. Waldock, K. Edward, C. Poustie (WAM T70202, T74315-T74316).

Etymology: This species is named for its occurrence in the montane regions of the Stirling Range National Park (montanus, Latin, pertaining to mountains).

Diagnosis: Atelomastix montana is similar to A. tumula, A. danksi and A. poustiei as the anterior gonopod sclerite $a$ is broad and concave sub-medially enveloping an elongate flagellum beneath a broad distal hood. However, it can be distinguished from other species because sclerite $a$ is only distally bifurcated with the medial process longer than the lateral process, and sclerite $b$ tapers to a narrow point, not extending to sclerite $c$, with the basal process longer than wide.

Description: Male (holotype). Colour (Fig. 1): head, collum, anal segment dark brown, ozopores and legs golden-brown, prozonites blue grey, metazonites dark brown to grey in preserved specimens.

Body: ca. $18 \mathrm{~mm}$ long and ca. $1.6 \mathrm{~mm}$ wide at collum. With 51 trunk segments, 91 pairs of legs, last 2 segments without legs.

Head: with numerous ocelli (Fig. 66), ca. 29, in 4 rows (5: 6: 8: 10).

Gonopods: anterior gonopods (Figs. 114, 115) very large, heavily sclerotised and complex in structure, 2.19 times longer than broad; sclerite $a$ with swollen base that forms broad, concave area where pseudoflagellum emerges, and broad, curved distal hood; sub-distal edge of concave area of sclerite $a$ with 3-6 setae $(\mathrm{n}=4)$; upper distal face of sclerite $a$ with 12-14 $(\mathrm{n}=4)$ short blunt setae; pseudoflagellum long, elongate and partially obscured by broadened distal hood; sclerite $b$ elongate and curved, tapering to a very narrow, curved, rounded tip, setae absent; basal process of sclerite $b$ broad and triangular, 0.33 times the length of the main process; sclerite $c$ slightly longer than sclerite $b$, broad and slightly concave medially, slightly tapering to a blunt, concave tip, with 6-10 setae $(\mathrm{n}=4)$ on internal concave face; with 1 seta on sub-basal edge of sclerite $b$ instead group of setae where sclerites overlap, and group of 12-14 $(\mathrm{n}=4)$ short setae sub-basally on sclerite $c$; posterior gonopods inconspicuous, small, with several small setae on interno-lateral face of each gonopod.

Dimensions (mm): holotype male (paratype male, WAM T69804): length ca. 18, width ca. 1.6, L/W=11.2; sclerite $a 0.979 / 0.485(1.024 / 0.476)$, setae $12+6(12+4)$; sclerite $b 0.431(0.448)$, basal process of sclerite $b$ 0.142 (0.176), setae $0(0)$; sclerite $c 0.787$ (0.816), setae 10 (10).

Female. Similar to male, other than sexual characters, and slightly larger.

Distribution and habitat: Atelomastix montana has been found at a number of sites in the eastern part of Stirling Range National Park, including Pyungoorup Peak, near Coyanarup Peak, and along the South Isongerup Track (Fig. 6). 
Atelomastix nigrescens Attems 1911: 195-196, Figs. 81-84; Attems 1914: 293; Chamberlin 1920: 167; Verhoeff 1924: 133.

Type material: AUSTRALIA: Western Australia: 1 male syntype, Jarrahdale, Hamburger südwest-australischen Forschungsreise, Station 129 [32²0'S, 116 03'E], 19-20 September 1905, W. Michaelsen and R. Hart-

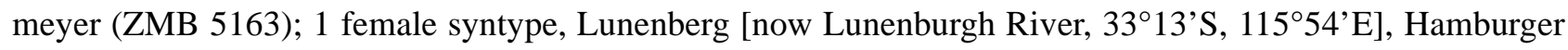
südwest-australischen Forschungsreise, Station 138, 22 September 1905, W. Michaelsen, R. Hartmeyer (ZMH).

Other material examined: AUSTRALIA: Western Australia: 4 males, Boddington, Forestry Department, 3313'S, $116^{\circ} 05^{\prime}$ E, 8 May 1980, pitfall trap, D. Halford, M. Sawle (WAM T47924); 2 males, 2 females, SW. of Boddington, Worsley Alumina, 33 ${ }^{\circ} 03^{\prime} \mathrm{S}, 116^{\circ} 10^{\prime} \mathrm{E}$, hand collected at night, 31 May 2006, J. Hynes (WAM T77052-T77053, T85869); 6 males, 4 females, Mount Cooke, 32¹5'00”S, 116¹0'48”E, 7 August 1990, M.S. Harvey, J.M. Waldock, M. Peterson (WAM T47900, T47901, T47906); 1 male, Mount Cooke, 32¹5'00”'S, 116¹0'48”'E, 31 July 1991, pitfall trap, M.S. Harvey, J.M. Waldock (WAM T47914); 3 males, 10 females, Mount Cooke, 32¹5'00”S, 116 ${ }^{\circ} 10^{\prime} 48^{\prime \prime}$, August 2003, hand collected, M.S. Harvey et al. (WAM T69772); 1 male, Jarrahdale mine area, 32¹7'42”S, 11608’18’E, April 1998, pitfall trap, L. Ashby (WAM T47942); 2 males, Churchmans Brook, 3209'S, 11605'E, 16 May 1996, hand collected, O. Mueller (WAM T47913); 3 males, 9 females, W. of Collie, Labour Road, 3315’31"S, 11603’37"E, 21 May 2007, hand collected, W. Bancroft (WAM T83392).

Diagnosis: Atelomastix nigrescens differs from all other species of Atelomastix in the shape and size of the lateral process of sclerite $c$ and the shape of sclerite $b$. This species exhibits a slight medial bifurcation of sclerite $c$ which is assymmetrical, the elongate lateral process is subdistally curved, tapers to a point, and is oriented medially at a similar height to the curved distal tip of sclerite $b$. The distal tip of sclerite $b$ is not significantly enlarged, is of similar shape and size to that of sclerite $c$, and curves to come into contact with the distal tip of sclerite $c$.

Description: Male (WAM T85869). Colour: generally dark brown in colour, head and mouthparts fawn, legs chocolate brown; prozonites chocolate brown; metazonites mottled dark brown in preserved specimens. Body: ca. $35 \mathrm{~mm}$ long and ca. $1.9 \mathrm{~mm}$ wide at collum. With 49 trunk segments, 87 pairs of legs, last 2 segments without legs.

Head: with 37 ocelli (Fig. 67), arranged in 7 rows (1:2:5:5: 7: 8:9).

Gonopods: anterior gonopods (Figs. 116, 117) heavily sclerotised, 2.3 times longer than broad; sclerite $a$ with swollen base that forms broad, curved distal hood; upper distal face of sclerite $a$ with 20 short blunt setae; pseudoflagellum elongate and visible beneath distal hood; sclerite $b$ curved distally forming a narrow rounded tip, with 6 setae; basal process of sclerite $b$ wider than long, 0.02 times length of main process; sclerite $c$ not bifurcate, curved sub-distally, with 8 setae; group of 13 short setae sub-basally on sclerite $c$; anterior gonopods inconspicuous, small, with several small setae on interno-lateral face of each gonopod.

Dimensions (mm): male, WAM T85869: length ca. 35, width ca. 1.9; L/W=18.4; sclerite $a$ 1.472/0.641, setae 20; sclerite $b 0.538$, basal process of sclerite $b 0.035$, setae 8 ; sclerite $c 0.976$, setae 8 .

Female. Similar to male, other than sexual characters, and slightly larger.

Distribution and habitat: Atelomastix nigrescens was originally described from Jarrahdale and Lunenberg in southwestern Australia (Attems 1911). This species is fairly common and widespread in jarrah (Eucalyptus marginata) forests within the Darling Range (Fig. 4). 
Atelomastix poustiei, sp. nov.

Figs. 6, 68, 120, 121.

Type material: AUSTRALIA: Western Australia: holotype male, Wedge Hill, Stirling Range National Park, 34²5'13”S, 118 10’58”'E, hand collected, 9 April 2004, M.S. Harvey, J.M. Waldock, K.L. Edward, C. Poustie (WAM T72775). Paratype: 1 male, collected with holotype (WAM T72774).

Other material examined: AUSTRALIA: Western Australia: 6 females, collected with holotype (WAM T70201); 3 males, 3 females, Wedge Hill, Stirling Range National Park, 342'ㄱ'S, $118^{\circ} 11^{\prime}$ E, wet pitfall traps, 8 April 1997, M.S. Harvey, J.M. Waldock, B.Y. Main (WAM T69818).

Etymology: This species is named for Cameron Poustie who assisted in the collection of the type specimens.

Diagnosis: Atelomastix poustiei is similar to A. tumula, A. danksi and A. montana as the anterior gonopod sclerite $a$ is broad and concave sub-medially enveloping an elongate pseudoflagellum beneath a broad distal hood. However, it can be distinguished from other species because sclerite $a$ is only distally bifurcated with the medial process longer than the lateral process, and the tip of sclerite $b$ slightly tapers to a rounded tip, instead of a narrow pointed tip in A. montana. This species also has a smaller gonopod (total length=1.05$1.06 \mathrm{~mm}$ ) compared with A. danksi (1.1-1.2 mm), and A. tumula (1.15-1.25 mm).

Description: Male (holotype). Colour: live specimens dark blue-grey with lighter bands between segments; head, antennae, ozopores and legs yellow-brown, rest light blue grey, prozonites light blue, metazonites yellow brown to pale white in preserved specimens.

Body: ca. $30 \mathrm{~mm}$ long and ca. $1.9 \mathrm{~mm}$ wide at collum. With 42 trunk segments, 73 pairs of legs, last 2 segments without legs.

Head: with ca. 21 ocelli (Fig. 68), in 4 rows (2: 5: 6: 8).

Gonopods: anterior gonopods (Figs. 120, 121) very large, heavily sclerotised and complex in structure, 2.13 times longer than broad; sclerite $a$ with swollen base that forms broad, concave area where pseudoflagellum emerges, and broad, curved distal hood; sub-distal edge of concave area of sclerite $a$ with 8 setae; upper distal face of sclerite $a$ with 8 short blunt setae; pseudoflagellum long, elongate and partially obscured beneath broadened distal hood; sclerite $b$ elongate and curved distally, terminating in blunt, rounded tip, with 1 subdistal seta; basal process of sclerite $b$ large, triangular, slightly curved distally, tapering to form rounded tip, 0.36 times the length of the main process; sclerite $c$ slightly longer than sclerite $b$, medial section relatively narrow, slightly tapering to a blunt concave tip, with 5-9 setae $(n=2)$ on internal concave face; with group of 6 $(\mathrm{n}=2)$ fine setae on sub-basal edge of sclerite $b$ instead of single sub-basal setae where sclerites overlap, and group of 10-12 ( $\mathrm{n}=2)$ short setae sub-basally on sclerite $c$; posterior gonopods inconspicuous, small, with several small setae on interno-lateral face of each gonopod.

Dimensions (mm): holotype male (paratype male, WAM T72774): length ca. 30 (24), width ca. 1.9 (1.7), $\mathrm{L} / \mathrm{W}=15.8(14.1)$; sclerite $a 1.05 / 0.493(1.06 / 0.527)$, setae $8+8(7+2)$; sclerite $b 0.474(0.448)$, basal process of sclerite $b 0.162$ (0.176), setae 1 (1); sclerite $c 0.912$ (0.848), setae 5 (9).

Female. Similar to male, other than sexual characters, and slightly larger.

Distribution and habitat: Atelomastix poustiei is only known from Wedge Hill on the eastern side of the Stirling Range National Park (Fig. 6) and has been collected using pitfall traps and hand collecting under logs, leaf litter and bark. 
Type material: AUSTRALIA: Western Australia: holotype male, Kangawarie clearing, ca. $50 \mathrm{~km} \mathrm{NW}$. of

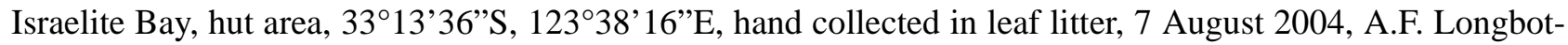
tom (WAM T72121). Paratype: 1 female, collected with holotype (WAM T72122).

Etymology: This species is named for the serrate or saw-shaped distal edge of the male gonopod sclerite $b$ (prionos, Greek, saw).

Diagnosis: Atelomastix priona can be distinguished from other species by the distinctive serrated, or sawlike distal edge of sclerite $b$. In addition, sclerite $c$ is not bifurcate, has a concavity on the interno-lateral side of the gonopod, is distally tapering and curved, and the distal edge is similar in height to sclerite $b$.

Description: Male (holotype). Colour: head, collum, anal segment, antennae, and anal valves dark brown, legs and gonopod light brown; prozonites mottled chocolate brown, metazonites dark brown to golden brown in preserved specimen.

Body: ca. $42 \mathrm{~mm}$ long and ca. $2.6 \mathrm{~mm}$ wide at collum. With 61 trunk segments, 111 pairs of legs, last 2 segments without legs.

Head: with ca. 53 ocelli (Fig. 69), arranged in 6 rows (6: 7: 9: 10: 10: 11).

Gonopods: anterior gonopods (Figs. 122-124) lightly sclerotised, 2.4 times longer than broad; sclerite $a$ with swollen base that forms broad, curved distal hood; upper distal face of sclerite $a$ with 23 short blunt setae; pseudoflagellum relatively short and partially visible beneath distal hood; sclerite $b$ broad, slightly curved distally, distal edge serrate like saw, with 16 short setae; basal process of sclerite $b$ small short, 0.03 times length of main process; sclerite $c$ same height as sclerite $b$, slightly bifurcate, lateral process long, thin, slightly curved distally, medial process very small, triangular, with 3 setae between lateral and medial processes; sub-basal setae absent where sclerites overlap and group of 20 short setae sub-basally on sclerite $c$; posterior gonopods inconspicuous, small, with several small setae on interno-lateral face of each gonopod.

Dimensions (mm): holotype male: length ca. 42, width ca. 2.6 ( $\mathrm{L} / \mathrm{W}=16.4)$; sclerite $a 1.544 / 0.64$, setae 23; sclerite $b 0.497$, basal process of sclerite $b 0.045$, setae 16 ; sclerite $c 1.00$, setae 3 .

Female. Similar to male, other than sexual characters, and slightly larger.

Distribution and habitat: This species is only known from one male and one female collected from Kangawarie clearing, about $50 \mathrm{~km}$ northwest of Israelite Bay (Fig. 8).

\section{Atelomastix psittacina, sp. nov.}

Figs. 9, 70, 125-127.

Type material: AUSTRALIA: Western Australia: holotype male, St Mary River, $5 \mathrm{~km}$ inland, Fitzgerald River National Park, 34¹0'S, 119³2'E, hand collected under rock, 31 May 1994, M.S. Harvey, J.M. Waldock (WAM T73956). Paratype: 1 male, collected with holotype (WAM T73957).

Other material examined: AUSTRALIA: Western Australia: 2 males, collected with holotype (WAM T47915); 2 males, East Mount Barren slopes, Fitzgerald River National Park, 335'', $120^{\circ} 01^{\prime}$ E, hand collected, 26 May 1994, M.S. Harvey, J.M. Waldock, G. Harrold, N. Brown (WAM T47918); 27 males, 35 females, East Mount Barren slopes, Fitzgerald River National Park, 3355'29'S, 12001'05'E, hand collected under rocks, 26 May 2007, M.C. Leng, M.L. Moir (WAM T80786, T80788); 2 males, 1 female, Eyre Range,

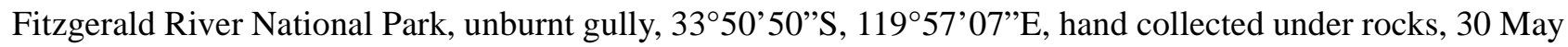
2007, M.C. Leng, M.L. Moir (WAM T80795); 6 males, 7 females, Eyre Range, near summit of small hill, Fitzgerald River National Park, 33 51'11'S, 11958'07'E, tulgren funnel leaf litter, 30 May 2007, M.C. Leng, M.L. Moir (WAM T81056, T80791); 11 males, 25 females, Rocky outcrop NE. of Point Edwards, Fitzgerald River National Park, 3357’37’S, 11957’28’'E, hand collected under rocks, 26 May 2007, M.C. Leng, M.L. 
Moir (WAM T80762-T80763); 23 males, 35 females, Whoobarup Range, burnt summit, Fitzgerald River National Park, 3356’20’S, 11950'52’E, hand collected under rocks, 31 May 2007, M.C. Leng, M.L. Moir (WAM T80748, T80749); 1 male, 2 females, Whoobarup Range, unburnt gully, Fitzgerald River National Park, 3356'17'S, 119 51'24'E, hand collected under rocks, 31 May 2007, M.C. Leng, M.L. Moir (WAM

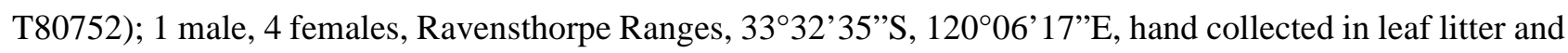
under rocks, 21 May 2007, M.C. Leng, M.L. Moir (WAM T80943); 4 males, 5 females, Ravensthorpe

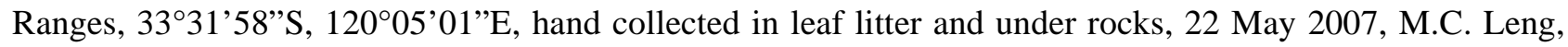
M.L. Moir (WAM T80957); 4 males, 6 females, Ravensthorpe Ranges, 3330'13”S, 12001'58”E, hand collected in leaf litter, 23 May 2007, M.C. Leng, M.L. Moir (WAM T80974); 1 male, Mount Chester, Ravensthorpe Ranges, $33^{\circ} 36^{\prime} 18^{\prime \prime}$ S, $120^{\circ} 08^{\prime} 34^{\prime \prime E}$, hand collected under rock, 10 September 2007, M.C. Leng (WAM T81294); 1 male, 7 females, Ravensthorpe Ranges, 33³6'59”S, 12009'38”E, hand collected in leaf litter, 13 September 2007, M.C. Leng, J. Newell (WAM T81296); 2 males, 5 females, Ravensthorpe Ranges, 33 38' 16"S, 120 10'46"'E, hand collected in leaf litter and under rocks, 17 May 2007, M.C. Leng, M.L. Moir (WAM T80880); 1 male, 4 females, Ravensthorpe Ranges, 3340'57.00S, 120¹7'39.02E, hand collected in leaf litter, 18 May 2007, M.C. Leng, M.L. Moir (WAM T80893); 1 male, 11 females, Ravensthorpe Ranges, 33 $34^{\prime} 35^{\prime \prime}$ S, $120^{\circ} 13^{\prime} 45^{\prime \prime}$, hand collected in leaf litter and under rocks, 19 May 2007, M.C. Leng, M.L. Moir (WAM T80903); 1 male, 4 females, Ravensthorpe Ranges, 3343’38.02S, 120¹3’24.06E, hand collected in leaf litter and under rocks, 19 May 2007, M.C. Leng, M.L. Moir (WAM T80905); 1 male, 5 females, Ravenst-

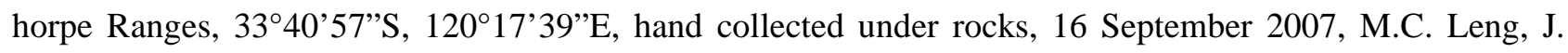
Newell (WAM T81297); 6 males, 14 females, Ravensthorpe Ranges, 3340'57’'S, 120¹7'39'E, hand collected in leaf litter and under rocks, 19 September 2007, M.C. Leng, M.L. Moir (WAM T80908); 2 males, 1

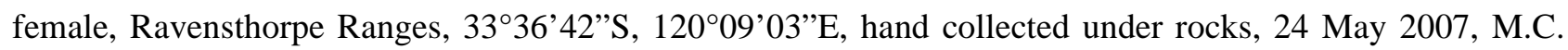
Leng, M.L. Moir (WAM T80997); 1 male, 1 female, Ravensthorpe Ranges, 3338'19”S, 120¹1'16”E, hand collected in leaf litter and under rocks, 28 May 2007, M.C. Leng, M.L. Moir (WAM T81014); 3 males, 1

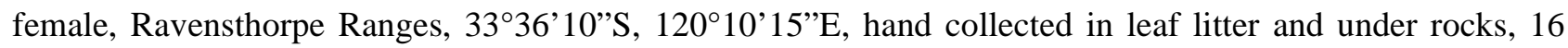
May 2007, M.C. Leng, M.L. Moir (WAM T80869); 3 males, 1 female, Ravensthorpe Ranges, 33³6'15”S, $120^{\circ} 10^{\prime 22}$ 'E, hand collected in leaf litter, 16 May 2007, M.C. Leng, M.L. Moir (WAM T80875).

Etymology: This species is named for the parrot beak-shaped distal tip of the male gonopod sclerite $b$ (psittacinus, Latin, of parrots).

Diagnosis: Sclerite $c$ of the male gonopod of Atelomastix psittacina is not bifurcated, but tapers to a straight rounded tip, which is slightly distally enlarged and generally shorter than the distal edge of sclerite $b$. Sclerite $b$ is variable in shape but generally curved distally and shaped like a bird's head. This species is similar to A. melindae and A. culleni but can be distinguished by the tapering distal tip of sclerite $c$ that is rounded distally and can be symmetrical to slightly asymmetrical compared with the bifurcated, angular distal tip of $A$. melindae. It can be distinguished from A. culleni by the concavity on the interno-lateral side of the gonopod, and the curved hook tip of sclerite $b$ compared with the broadened distal tip, internally placed concavity of sclerite $c$, and rounded tip of sclerite $b$ in A. culleni.

Description: Male (holotype). Colour: generally dark brown; legs, mouthparts, gonopods golden brown; prozonites brown to dark brown, metazonites golden brown in preserved specimens.

Body: ca. $27 \mathrm{~mm}$ long and ca. $1.8 \mathrm{~mm}$ wide at collum. With 52 trunk segments, 93 pairs of legs, last 2 segments without legs.

Head: with ca. 40 ocelli (Fig. 70), arranged in 5 rows (5: 7: 9: 9: 10).

Gonopods: anterior gonopods (Figs. 125-127) lightly sclerotised, 2.4 times longer than broad; sclerite $a$ with swollen base that forms broad, curved distal hood; upper distal face of sclerite $a$ with 24-25 (n=2) short blunt setae; pseudoflagellum relatively short and partially visible beneath distal hood; sclerite $b$ variable in shape but generally broad and curved distally forming a beak-like hook, with 4-8 $(n=2)$ setae; basal process of sclerite $b$ small and triangular, 0.05 times length of main process; sclerite $c$ not bifurcate, with rounded distal 
tip varying in shape from symmetrical to slightly asymetrical, with 6-7 setae $(n=2)$; one sub-basal setae present where sclerites overlap and group of 12 short setae sub-basally on sclerite $c$; posterior gonopods inconspicuous, small, with several small setae on interno-lateral face of each gonopod.

Dimensions (mm): holotype male (paratype male, WAM T73957): length ca. 27 (31), width ca. 1.8 (1.9); L/W=14.7 (16.9); sclerite $a 1.168 / 0.480$ (1.2/0.576), setae 24 (25); sclerite $b 0.426(0.435)$, basal process of sclerite $b 0.058$ (0.032), setae 8 (4); sclerite $c 0.736$ (0.8), setae 7 (6).

Female. Similar to male, other than sexual characters, and slightly larger.

Distribution and habitat: This species has been collected from a number of localities in leaf litter, in creek beds and under rocks in the coastal granite outcrops of the Fitzgerald River National Park and the Ravensthorpe Ranges (Fig. 9).

\section{Atelomastix rubricephala, sp. nov.}

Figs. 2, 5, 23-33, 71, 128, 129.

Type material: AUSTRALIA: Western Australia: holotype male, S. of Mount Manypeaks, Waychinicup Nature Reserve, 34'54'29'S, $118^{\circ} 16^{\prime} 07^{\prime}$ 'E, hand collected in gully, 14 March 2005, M.S. Harvey, J.M. Waldock, K.L. Edward (WAM T71606). Paratypes: Waychinicup Nature Reserve: 2 males, collected with holotype (WAM T71607, T72608); 8 males, 13 females, collected with holotype (WAM T69936); 1 male, Robinsons Gully, Two Peoples Bay Nature Reserve, 34 59'30’S, 118 11'52”E, hand collected under granite rocks, 28 May 2004, M.S. Harvey (WAM T71759).

Other material examined: AUSTRALIA: Western Australia: 4 males, 9 females, Waychinicup Nature Reserve, gully, 3454'14'S, 118²3'57'E, hand collected under leaf litter, 24 October 2006, M.L. Moir, A. Sampey (WAM T78632-T78633); 1 male, gully, Waychinicup Nature Reserve, 3454'14”'S, 118²3'57'E, tullgren funnel, under leaf litter, 24 October 2006, M.L. Moir, A. Sampey (WAM T81064); 3 males, 4 females, Mount Manypeaks, granite outcrop, Waychinicup Nature Reserve, 3453'45”S, 118 $18^{\circ} 07^{\prime}$ 'E, hand collected under leaf litter, 26 October 2006, M.L. Moir, A. Sampey (WAM T78767-T78768); 5 females, Mount Manypeaks, granite outcrop, Waychinicup Nature Reserve, 34 $54^{\prime} 02$ 'S, 118 15 '58'E, hand collected under granite rock, 1 December 2006, M.L. Moir, K.E.C. Brennan, B. Atkinson (WAM T78769-T78770); 7 males, 9 females, Mount Manypeaks, gully near summit, Waychinicup Nature Reserve, 3453'49"S, 118 ${ }^{\circ} 5^{\prime} 57^{\prime}$ 'E, hand collected under logs, 1 December 2006, M.L. Moir, K.E.C. Brennan, B. Atkinson (WAM T78773-T78774); 4 females, Mount Manypeaks, Waychinicup Nature Reserve, 3453'57"S, 118¹5'43"E, hand collected under logs and rocks, 1 December 2006, M.L. Moir, K.E.C. Brennan, B. Atkinson (WAM T78775-T78776); 2 males, 3 females, Waychinicup Nature Reserve, 3454'12'S, 118 23'59'E, hand collected under leaf litter, 24 October 2006, M.L. Moir, A. Sampey (WAM T78626-T78627); 4 males, 2 females, Waychinicup Nature Reserve, 345' 12'S, $118^{\circ} 23^{\prime} 59^{\prime}$ 'E, tullgren funnel, under leaf litter, 24 October 2006, M.L. Moir, A. Sampey (WAM T81065); 3 males, 3 females, S. of Mount Manypeaks, Surprise Gully, 34 54'11'S, 118 23'57'”, hand collected under leaf litter, 13 March 2007, M.L. Moir et al. (WAM T78955); 1 male, Robinsons Gully, Two Peoples Bay Nature Reserve, 3459’30”S, 118 11'52”E, hand collected under granite rocks, 28 May 2004, M.S. Harvey (WAM T71760); 3 males, 5 females, Robinsons Gully, Two Peoples Bay Nature Reserve, 3459'30"S, 118¹1'52'E, hand collected under granite rocks, 28 May 2004, M.S. Harvey (WAM T69939); 2 males, 4 females, Fishermans gully, Two Peoples Bay Nature Reserve, 3500’37’S, 118 $11^{\prime} 30^{\prime \prime}$, hand collected, 19 October 2006, M.L. Moir, J.M. Waldock (WAM T78605-T78606); 3 females, Fishermans gully, Two Peoples Bay Nature Reserve, 3500'37’S, 118¹1'30'E, Tullgren funnel, 19 October 2006, M.L. Moir, J.M. Waldock (WAM T81067); 6 males, 4 females, Fishermans gully, Two Peoples Bay Nature Reserve, 3500'39'S, 118 11'25'E, hand collected under leaf litter, 19 October 2006, M.L. Moir, J.M. Waldock (WAM T78603-T78604); 1 male, 12 females, Two Peoples Bay Nature Reserve, granite out- 
crop, 3500'20'S, 118¹1'10”'E, hand collected under granite rocks, 19 October 2006, M.L. Moir, J.M. Waldock (WAM T78607-T78608); 3 males, 4 females, Two Peoples Bay Nature Reserve, granite outcrop, 34 59'18'S, $118^{\circ} 11^{\prime} 44^{\prime \prime}$, hand collected under granite rocks, 14 October 2006, M.L. Moir, J.M. Waldock (WAM T78593-T78594); 5 males, 6 females, Two Peoples Bay Nature Reserve, marri forest, 3459'11'S, $118^{\circ} 11^{\prime} 28^{\prime \prime}$, hand collected in marri leaf litter, 14 October 2006, M.L. Moir, J.M. Waldock (WAM T78595T78596); 6 males, 15 females, Two Peoples Bay Nature Reserve, marri forest, Two Peoples Bay Nature Reserve, 3459'11'S, $118^{\circ} 11^{\prime} 28^{\prime \prime}$ E, tullgren funnel, under leaf litter, 14 October 2006, M.L. Moir, J.M. Waldock (WAM T81066); 3 males, 4 females, Robinson's gully, Two Peoples Bay Nature Reserve, 3459'41'S, $118^{\circ} 11^{\prime} 58^{\prime \prime}$, hand collected in sedges, 14 October 2006, M.L. Moir, J.M. Waldock (WAM T78591-T78592);

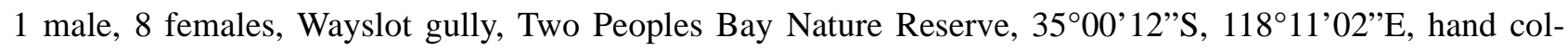
lected under logs, 19 October 2006, M.L. Moir, J.M. Waldock (WAM T78601-T78602).

Etymology: This species is named for its distinctive red head (rubra-, Latin, red; kephale, Greek, head).

Diagnosis: This species is characterised by a distinctive red head and collum, and grey brown body. The shape of the male gonopod sclerites is also distinctive. Atelomastix rubricephala has a medially bifurcated sclerite $c$, with the medial process much longer and broader than the smaller lateral process. Sclerite $b$ is broad, straight, and the tip is longer and extends beyond sclerite $c$.

Description: Male (holotype). Colour (Fig. 2): live specimens with red head and collum fading slightly when preserved, legs yellow-brown, anal segment brown, prozonites grey-brown, metazonites dark brown to pale grey in preserved specimens.

Body: ca. $30 \mathrm{~mm}$ long and ca. $1.9 \mathrm{~mm}$ wide at collum. With 50 trunk segments, 89 pairs of legs, last 2 segments without legs.

Head (Figs. 23, 25): with ca. 30 ocelli (Fig. 71), arranged in 4 rows (5: 8: 8: 9).

Gonopods: anterior gonopods (Figs. 29-33, 128, 129) lightly sclerotised, 2.5 times longer than broad; sclerite $a$ with swollen base and curved distal hood; upper distal face of sclerite $a$ with 10-12 (n=3) short blunt setae; pseudoflagellum short and distally visible; sclerite $b$ flat, broad, and distally rounded, $9-15(\mathrm{n}=3)$ distal setae; basal process of sclerite $b$ very small, 0.009 times length of main process; sclerite $c$ bifurcate, lateral process much smaller than broad medial process, 4 setae $(n=3)$ in row below bifurcation and 1-3 $(n=3)$ on medial process; $1-3(n=3)$ sub-basal setae where sclerites overlap and group of $10(n=3)$ short setae subbasally on sclerite $c$; posterior gonopods inconspicuous, small, with several small setae on interno-lateral face of each gonopod.

Dimensions (mm): holotype male (paratype male, WAM T71607): length ca. 30 (32), width ca. 1.9 (1.8), $\mathrm{L} / \mathrm{W}=15.5$ (17.3); sclerite $a 1.136 / 0.448$ (1.088/0456), setae 10 (12); sclerite $b 0.491$ (0.445), basal process of sclerite $b 0.01$ (0.02), setae 15 (11); sclerite $c 0.803$ (0.0.773), setae 5 (7).

Female. Similar to male, other than sexual characters, and slightly larger.

Distribution and habitat: This species has been collected from a number of sites beneath granite rocks, in marri (Corymbia calophylla) leaf litter, and amongst sedges in Waychinicup Nature Reserve and Two Peoples Bay Nature Reserve, east of Albany (Fig. 5).

\section{Atelomastix sarahae, sp. nov.}

Figs. 9, 72, 130, 131.

Type material: AUSTRALIA: Western Australia: holotype male, Mount Arid, Cape Arid National Park,

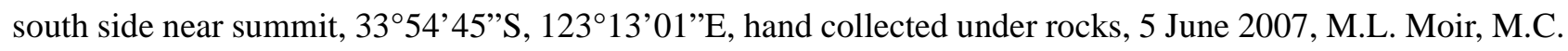
Leng (WAM T85863). Paratypes: Mount Arid, Cape Arid National Park: 9 males, 25 females, collected with holotype (WAM T80671); 38 males, 34 females, collected with holotype (WAM T80674).

Etymology: The specific epithet is a patronym in honour of Sarah Comer who has collected numerous specimens of Atelomastix in southwestern Western Australia. 
Diagnosis: The male gonopod morphology of Atelomastix sarahae differs from other species as sclerite $c$ is not bifurcated but slightly curved distally with an interno-lateral concavity that extends to the sub-distal tip of the sclerite. Sclerite $b$ is much higher than the tip of sclerite $c$, extends to the edge of sclerite $c$ and curves distally to a pointed tip.

Description: Male (holotype). Colour: generally chocolate-brown with mottled blue-grey; legs, antennae, mouthparts, and gonopods golden brown; ozopores distinct and golden brown; prozonites chocolate brown, metazonites mottled blue-grey to brown in preserved specimens.

Body: ca. $27 \mathrm{~mm}$ long and ca. $1.7 \mathrm{~mm}$ wide at collum. With 56 trunk segments, 101 pairs of legs, last 2 segments without legs.

Head: with ca. 45 ocelli (Fig. 72), arranged in 7 rows (1: 4: 7: 9: 8: 8: 8).

Gonopods: anterior gonopods (Figs. 72, 130, 131) heavily sclerotised, 1.9-2.2 mm $(\mathrm{n}=2)$ times longer than broad; sclerite $a$ with swollen base that forms broad, curved distal hood; upper distal face of sclerite $a$ with 28-31 $(n=2)$ short blunt setae; pseudoflagellum relatively short and partially visible beneath broad distal hood; sclerite $b$ relatively broad, curved subdistally, tapering sharply to a pointed curved tip, with 9-14 ( $\mathrm{n}=2)$ short setae; basal process of sclerite $b$ short and triangular, 0.02-0.03 $(\mathrm{n}=2)$ times length of main process; sclerite $c$ shorter than sclerite $b$, not bifurcated but slightly curved distally with interno-lateral concavity that extends to sub-distal tip of sclerite, with $2-5$ setae in concavity $(n=2)$; sub-basal setae not visible where sclerites overlap and group of $12(\mathrm{n}=2)$ short setae sub-basally on sclerite $c$; anterior gonopods inconspicuous, small, with several small setae on interno-lateral face of each gonopod.

Dimensions (mm): holotype male (paratype male, WAM T80671): length ca. 27, width ca. 1.7, L/W=15.9; sclerite $a 1.072 / 0.477(1.088 / 0.573)$, setae 28 (31); sclerite $b 0.418(0.414)$, basal process of sclerite $b 0.016$ (0.026), setae 9 (14); sclerite $c 0.720$ (0.800), setae 5 (2).

Female. Similar to male, other than sexual characters, and slightly larger.

Distribution and habitat: Atelomastix sarahae is only known from rocky outcrops near the summit of Mount Arid in the Cape Arid National Park (Fig. 9).

\section{Atelomastix solitaria Jeekel}

Atelomastix solitaria Jeekel 2009: 31-34, figs. 1-5.

Type material: AUSTRALIA: Victoria: holotype male, Grampians, near Silverband Falls [37' $11^{\prime} S$, $142^{\circ} 31$ 'E], under bark of Eucalyptus sp. in forest, 6 May 1978, J.J.H. Szent-Ivany, M.L. Szent-Ivany (SAMA), not examined. Paratypes: 2 males, 2 females, collected with holotype (SAMA), not examined.

Other material: AUSTRALIA: Victoria: 4 juveniles, collected with holotype (SAMA), not examined.

Description: See Jeekel (2009).

Distribution and habitat: Atelomastix solitaria is only known from The Grampian Ranges in western Victoria, where they were found under the bark of a eucalypt tree.

\section{Atelomastix tigrina, sp. nov.}

Figs. 3, 5, 73, 132-135.

Type material: AUSTRALIA: Western Australia: holotype male, The Cascades, Bluff Knoll, Stirling Range National Park, 34²2’32”S, $118^{\circ} 14^{\prime} 33^{\prime}$ 'E, hand collected, 6 April 2004, M.S. Harvey, J.M. Waldock, K.L. Edward, C. Poustie, A. Danks (WAM T74312). Paratypes: Stirling Range National Park: 1 male, collected with holotype (WAM T74311); 1 male, 2 females, collected with holotype (WAM T69440). 
Other material examined: AUSTRALIA: Western Australia: 6 males, The Cascades, Bluff Knoll, Stirling Range National Park, 34²2’29’S, 118 14'17'E, wet pitfall traps, 29 April 1996, M.S. Harvey, J.M. Waldock, B.Y. Main (WAM T47928); 1 male, The Cascades, Bluff Knoll, Stirling Range National Park, 3422'29'S, 118 14'17’'E, wet pitfall traps, 4 August 1996, M.S. Harvey, J.M. Waldock, B.Y. Main (WAM T47929); 1 male, 2 females, south of Pyungoorup Peak, Stirling Range National Park, 34²1'59"S, 118 19'44”'E, hand collection, 18 March 2005, M.S. Harvey, J.M. Waldock, K.L. Edward, S. Comer (WAM T72776); 4 males, Pyungoorup Peak, south face, Stirling Range National Park, 34²2’17’S, 118 19'20’E, wet pitfall traps, 4 August 1996, M.S. Harvey, J.M. Waldock, B.Y. Main (WAM T47930, T74313); 7 males, Pyungoorup Peak, south face, Stirling Range National Park, 34²2'17’'S, 118 $19^{\circ} 20^{\prime}$ 'E, wet pitfall traps, 27 April 1996, M.S. Harvey, J.M. Waldock, B.Y. Main (WAM T47927, T74314); 1 male, 1 female, Stirling

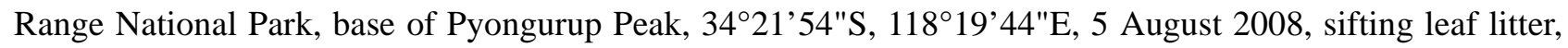
M.G. Rix, M.S. Harvey (WAM T54248, T54249); 3 females, Stirling Range National Park, base of Pyongurup Peak, 34²2’01"S, 118¹9’48"E, 5 August 2008, from ground, litter, M.G. Rix, M.S. Harvey (WAM T54250).

Etymology: This large, distinctive species is named for the distinctive black and yellow body stripes (tigrinus, Latin, of tigers).

Diagnosis: Specimens of Atelomastix tigrina are large (body width greater than $2.5 \mathrm{~mm}$, and length $42-61$ $\mathrm{mm}$ ) and, when alive, have a very striking colour pattern of black or dark brown with bright yellow-orange bands, similar to A. julianneae. This species can be distinguished by the distinctly angular shaped sclerite $b$ and very elongate basal process that extends behind the main process of the male gonopod. Sclerite $c$ is not bifurcate, is relatively straight, and shorter than sclerite $b$.

Description: Male (holotype). Colour (Fig. 3): live specimens with black to dark brown segments, head and legs with bright yellow-orange bands; prozonites dark brown, metazonites brown to bright yellow-orange in preserved specimens.

Body: ca. $56 \mathrm{~mm}$ long and ca. $3 \mathrm{~mm}$ wide at collum. With 65 trunk segments, 117 pairs of legs, last 2 segments without legs.

Head: with ca. 46 ocelli (Fig. 73), arranged in 6 rows (3: 6: 7: 10: 8:11).

Gonopods: anterior gonopods (Figs. 132-135) heavily sclerotised, 2.7 times longer than broad; sclerite $a$ with swollen base that forms broad, curved distal hood; upper distal face of sclerite $a$ with 18-20 (n=3) short blunt setae; pseudoflagellum short, broad, and entirely visible on externo-lateral side of gonopod but not visible on interno-lateral side, where it is concealed within distal hood; sclerite $b$ broad, angular, forming a blunt tip distally, with 4 erect setae $(\mathrm{n}=3)$ on sub-distal edge; basal process of sclerite $b$ very long and elongate, 0.16 times the length of the main process; sclerite $c$ shorter than sclerite $b$, not bifurcate, tapering to blunt tip, with 1-3 medial seta and 7-9 setae sub-distally on broad internal face $(n=3)$; one sub-basal setae present where sclerites overlap and group of 13 short setae sub-basally on sclerite $c$; posterior gonopods inconspicuous, small, with several small setae on interno-lateral face of each gonopod.

Dimensions (mm): holotype male (paratype male, WAM T74311): length ca. 56 (61), width ca. 3 (3), L/ $\mathrm{W}=18.7$ (20.3); sclerite $a 1.656 / 0.608$ (1.704/0.694), setae 18 (20); sclerite $b 0.701$ (0.733), basal process of sclerite $b 0.264(0.288)$, setae 4 (4); sclerite $c 1.088(1.184)$, setae $1+9(3+7)$.

Female. Similar to male, other than sexual characters, and slightly larger.

Distribution and habitat: This species is only known from The Cascades at Bluff Knoll and the south face of Pyungoorup Peak in Stirling Range National Park (Fig. 5). The surrounding vegetation is dominated by sparsely growing jarrah (Eucalyptus marginata) and marri (Corymbia calophylla). 
Atelomastix tumula, sp. nov.

Figs. 6, 74, 135, 136.

Type material: AUSTRALIA: Western Australia: holotype male, Bluff Knoll walking trail, Stirling Range National Park, $34^{\circ} 23^{\prime}$ 'S, $118^{\circ} 15^{\prime}$ E, hand collected, 6 April 2004, M.S. Harvey, J.M. Waldock, K.L. Edward, C. Poustie (WAM T74317). Paratypes: 1 male, collected with holotype (WAM T74318).

Other material examined: AUSTRALIA: Western Australia: 7 females, collected with holotype (WAM T70204).

Etymology: The specific name is an adjective based on the type locality, Bluff Knoll (tumulus, Latin, raised mound of earth).

Diagnosis: Atelomastix tumula is generally greenish brown or dark brown with pale bands, and is relatively large in size (body width $2.4 \mathrm{~mm}$, length $>44 \mathrm{~mm}$ ). This species is similar to A. danksi, A. montana, and A. poustiei as the anterior gonopod sclerite $a$ is broad and concave sub-medially. However, it can be distinguished by the presence of two bifurcations of sclerite $c$ of the male gonopod. This species exhibits a shallow asymmetrical distal bifurcation with a larger medial process and a deep asymmetrical medial bifurcation with a larger lateral process. The distal hood of sclerite $a$ is not as broad as similar species, but is rather deep with the elongate pseudoflagellum entirely exposed.

Description: Male (holotype). Colour: live specimens dark blue-grey with lighter bands between segments; head, antennae, ozopores and legs golden-brown, rest dark brown, prozonites green-brown, metazonites darker brown to pale white in preserved specimens.

Body: ca. $44 \mathrm{~mm}$ long and ca. $2.4 \mathrm{~mm}$ wide at collum. With 60 trunk segments, 109 pairs of legs, last 2 segments without legs.

Head: with ca. 21 ocelli (Fig. 74), arranged in 3 rows (6: 7: 8).

Gonopods: anterior gonopods (Figs. 135, 136) very large, heavily sclerotised and complex in structure, 2.14 times longer than broad; sclerite $a$ with swollen base that forms broad, concave area where pseudoflagellum emerges, and, curved distal hood that is characteristically domed; sub-distal edge of concave area of sclerite $a$ with 6 larger setae; upper distal face of sclerite $a$ with 22 short blunt setae; pseudoflagellum long, elongate and distally visible beneath broadened distal hood; sclerite $b$ elongate and curved, terminating in a blunt, rounded tip, with $0-1$ sub-distal setae; basal process of sclerite $b$ large, triangular, tapering to form rounded tip, 0.39 times the length of the main process; sclerite $c$ same height as sclerite $b$, almost bifurcate with medial section noticeably broad, slightly tapering to blunt concave tip, with 10 setae $(n=2)$ on internal concave face; with group of 6-8 $(n=2)$ fine setae on sub-basal edge of sclerite $b$ instead of single sub-basal setae where sclerites overlap, and group of 10 short setae sub-basally on sclerite $c$; posterior gonopods inconspicuous, small, with several small setae on interno-lateral face of each gonopod.

Dimensions (mm): holotype male (paratype male, WAM T74317): length ca. 44, width ca. 2.4, L/W=18.4; sclerite $a 1.248 / 0.584(1.152 / 0.558)$, setae $8+6(8+6)$; sclerite $b 0.520(0.499)$, basal process of sclerite $b$ 0.204 (0.202), setae 0 (1); sclerite $c 0.904$ (0.880), setae 3 (8).

Female. Unknown.

Distribution and habitat: Atelomastix tumula is known only from two males and seven females hand collected under rocks along the Bluff Knoll walking trail in the Stirling Range National Park (Fig. 6). The habitat consists of moist jarrah (Eucalyptus marginata) and marri (Corymbia calophylla) forest with a relatively thick understorey.

\section{Discussion}

Millipedes of the genus Atelomastix are shown to be extremely diverse with 27 species found in southwestern Australia from the Darling Range to Israelite Bay (Figs. 4-9), plus a further species in western Victoria 
(Jeekel 2009). Atelomastix species are considered to be short-range endemics as defined by Harvey (2002) as they exhibit low vagility, maintain very small ranges, and inhabit restricted Gondwanan relictual habitats. Few species are known from more than a $1,000 \mathrm{~km}^{2}$ along the coast of southern Western Australia. These distributions are not due to lack of collecting, as there have been extensive and comprehensive surveys for short-range endemic terrestrial invertebrates, including millipedes, in the region (Framenau, et al. 2008). The comprehensive nature of our collecting for Atelomastix millipedes is best exemplified by the distributions of the five species that have been found to occur in the Stirling Ranges. MSH has coordinated a series of collecting trips over the past 15 years that have utilised pitfall traps and hand collecting at various times of the year, but mostly during autumn, winter and spring, when adult male millipedes are known to be active. We recognise five species from the Stirling Range, all of which are endemic. Atelomastix danksi is the only species found in the western side of the range, where it occurs along a seasonally dry creek running east off Toolbrunup Peak. Atelomastix poustiei is restricted to Wedge Hill, a small isolated hill southeast of the main Stirling Range massif, where it occurs in a deeply dissected gully shaded by relatively tall eucalypt trees. Atelomastix tigrina occurs at the Cascades and along the south face of Pyungorup Peak. Atelomastix tumula has been found at one site on the Bluff Knoll walking trail. Atelomastix montana occurs at a number of sites in the eastern part of the range, including the low-lying slopes of Pyungoorup Peak, Coyanarup Peak and along the South Isongerup Track. Sympatric populations have only been found at one site, the south face of Pyungoorup Peak, where $A$. tigrina and A. montana occur under the same rocks.

Little evidence of mosaic distributions was found in Atelomastix. Mosaic patterns or lineage mosaics, are characterised by large generic distributions, limited species ranges, tightly fitted parapatric patterns with limited instances of sympatry, and minor differences between some species (Mesibov 2003a). These mosaic patterns are thought to be quite common in the Diplopoda, and have been documented for other millipedes (Shelley \& Whitehead 1986; Mesibov 2003b, 2003c).

Evidence suggests that speciation patterns seen in Atelomastix are mainly due to allopatric divergence in isolation, with species retaining similar niches, rather than adaptive radiation in sympatry (Edward 2003). Although there is some evidence of character displacement with regard to body size in sympatric species inhabiting the same habitats, it is likely that vicariance events were responsible for divergence and current speciation patterns within Atelomastix. The existence of marine, edaphic, and climatic barriers within southwestern Australia since the Eocene, is thought to have influenced the current distribution patterns of Atelomastix and may have been responsible for the high specific endemism in the region (Hopper, et al. 1996). However, it is noted that climatic and edaphic events alone have not been wholly responsible for patterns of speciation in the southwest (Edward 2003).

A number of endemic taxa in the region exhibit similar distribution and speciation patterns, providing a strong case that speciation patterns within Atelomastix could be explained in part by one or a number of vicariance events. These include mygalomorph spiders, such as Moggridgea O. Pickard-Cambridge, 1875, Teyl Main, 1975, Stanwellia Rainbow \& Pulleine, 1918, and Neohomogona Main, 1985 (Main 1991, 1999), the freshwater crayfish, Engaewa Riek, 1967 (Horwitz \& Adams 2000), frogs of the Geocrinia rosea (Harrison, 1927) complex (Edwards, et al. 2007; Wardell-Johnson \& Roberts 1996), and the onychophoran, Kumbadjena Reid, 2002 (Reid 2002). All these groups show similar patterns or evidence of similar biogeographic breaks in certain areas such as the Stirling Range, Porongurup Range, and granite outcrops along the coast including Torbay. However, no studies have shown such extensive speciation patterns, with mainly allopatric patterns and narrow ranges as seen in Atelomastix. This may have been the result of limited comprehensive collections, and future collecting may reveal a pattern similar to that of Atelomastix.

\section{Implications for conservation}

Like other millipedes, Atelomastix species have poor dispersal abilities and limited inter-population gene flow which leaves populations vulnerable to a wide range of threatening processes (Ponder \& Colgan 2002). 
Main threats include further fragmentation of habitats, extensive fire, increasing aridity, and rural and urban development. Atelomastix millipedes may be able to recolonise after fire, provided available refuges were nearby and the fire was not extensive, producing a barrier to migration. However, fire also reduces the amount of resources and protection available for millipedes, through the elimination of leaf litter and fallen debris.

Biogeographical patterns are important in prioritising habitats and taxa for conservation, and in maximising both representation and persistence of diversity (Moritz 2002). Current parameters used in the selection of terrestrial habitats for conservation are generally poor indicators of invertebrate assemblages and therefore inappropriate for many taxa of high conservation significance such as short-range endemics (Harvey 2002; Ponder \& Colgan 2002). Knowledge and inclusion of short-range endemics, such as Atelomastix millipedes, could assist in the prioritising of "hot-spots," or areas that have a concentration of short-range endemics, for conservation (Ponder \& Colgan 2002).

Phylogenetic analysis using molecular and morphological data, and estimation of molecular clocks may provide additional evidence for historical biogeographic hypotheses about Atelomastix, reveal relationships between species, aid in conservation, and possibly be used to predict speciation patterns elsewhere in the southwest. Further investigation and conservation of endemic species, particularly short-range endemics, is essential for the preservation of biodiversity and Gondwanan heritage within southwestern Australia.

\section{Acknowledgements}

We wish to thank H. Dastych (ZMH) and Jason Dunlop (ZMB) for the loan of type specimens, and the many collectors of specimens that contributed to this study, in particular Alan Longbottom, Melinda Moir, Julianne Waldock, Sarah Comer and Frances Leng. Funding for detailed field work in southwestern Australia was supplied to MSH by South Coast NRM, and we are grateful to Deon Utber (Department of Environment and Conservation, Albany) for facilitating this grant. Specimens were collected under permits issued by the Western Australian Department of Conservation and Land Management, later to become the Department of Environment and Conservation. We are very grateful to Dr Bob Mesibov for his support and provision of literature. This project had its genesis as a project during KLE's Honours thesis at the University of Western Australia, which was co-supervised by MSH, Mike Johnston, Brenton Knott and Jane Prince.

\section{References}

Attems, C. (1914) Die indoaustralischen Myriapoden. Archiv für Naturgeschichte, (A) 80, 1-398.

Attems, C.G. (1911) Myriopoda exkl. Scolopendridae. In: Michaelsen, W. \& Hartmeyer, R. (Eds.) Die Fauna SüdwestAustraliens. Gustav Fischer, Jena, pp. 147-204.

Brölemann, H.W. (1913) The Myriapoda in the Australian Museum. Part ii.- Diplopoda. Records of the Australian Museum, 10, 77-158.

Brown, R.W. (1956) Composition of scientific words. Smithsonian Institution Press, Washington, D.C.

Byrne, M., Yeates, D.K., Joseph, L., Kearney, M., Bowler, J., Williams, M.A.J., Cooper, S., Donnellan, S.C., Keogh, J.S., Leys, R., Melville, J., Murphy, D.J., Porch, N. \& Wyrwoll, K.-H. (2008) Birth of a biome: insights into the assembly and maintenance of the Australian arid zone biota. Molecular Ecology, 17, 4398-4417.

Chamberlin, R.V. (1920) The Myriopoda of the Australian region. Bulletin of the Museum of Comparative Zoology, 64, $1-269$.

Edgecombe, G. \& Barrow, L. (2007) A new genus of scutigerid centipedes (Chilopoda) from Western Australia, with new characters for morphological phylogenetics of Scutigeromorpha. Zootaxa, 1409, 23-50.

Edgecombe, G.D. (1998) Devonian terrestrial arthropods from Gondwana. Nature, 394, 172-175.

Edgecombe, G.D. (2005) A troglomorphic species of the centipede Crytops (Trigonocryptops) (Chilopoda: Scolopendromorpha) from Western Australia. Records of the Western Australian Museum, 22, 315-323.

Edward, K.L. (2003) Speciation and biogeography of the native millipede genus Atelomastix within southwestern Australia. School of Animal Biology. University of Western Australia, Crawley 
Edwards, D.L. (2007) Biogeography and speciation of a direct developing frog from the coastal arid zone of Western Australia. Molecular Phylogenetics and Evolution, 45, 494-505.

Edwards, D.L., Roberts, D. \& Keogh, S. (2007) Impact of Plio-Pleistocene arid cycling on the population history of a southwestern Australian frog. Molecular Ecology, 16, 2782-2796.

Edwards, D.L., Roberts, J.D. \& Keogh, J.S. (2008) Climatic fluctuations shape the phylogeography of a mesic directdeveloping frog from the south-western Australian biodiversity hotspot. Journal of Biogeography, 35, $1803-1815$.

Framenau, V.W., Moir, M.L. \& Harvey, M.S. (2008) Terrestrial Invertebrates of the south coast NRM region of Western Australia: short-range endemics in Gondwanan relictual habitats. Unpublished Report to the Southcoast Natural Resource Management Inc.

Haq, B.U., Hardenbol J. \& Vail, P.R. (1987) Chronology of fluctuating sea levels since the Triassic. Science, new series, 235, 1156-1167.

Harvey, M.S. (2002) Short-range endemism in the Australian fauna: some examples from non-marine environments. Invertebrate Systematics, 16, 555-570.

Hoffman, R.L. (1980) Classification of the Diplopoda. Muséum d'Histoire Naturelle, Genève.

Hoffman, R.L. (1990) Diplopoda. In: Dindal, D.L. (Ed.) Soil biology guide. John Wiley and Sons, New York, pp. 835860.

Hopper, S.D. (1979) Biogeographical aspects of speciation in the south west Australian flora. Annual Review of Ecology and Systematics, 10, 399-422.

Hopper, S.D. \& Gioia, P. (2004) The Southwest Australian Floristic Region: evolution and conservation of a global hot spot of biodiversity. Annual Review of Ecology and Systematics, 35, 623-650.

Hopper, S.D., Harvey, M.S., Chappill, J.A., Main, A.R. \& Main, B.Y. (1996) The Western Australian biota as Gondwanan heritage - a review. In: Hopper, S.D., Chappill, J.A., Harvey, M.S. \& George, A.S. (Eds.) Gondwanan heritage: past, present and future of the Western Australian biota. Surrey Beatty \& Sons, Chipping Norton, pp. 1-46.

Horwitz, P. \& Adams, M. (2000) The systematics, biogeography and conservation status of species in the freshwater crayfish genus Engaewa Riek (Decapoda: Parastacidae) from south-western Australia. Invertebrate Taxonomy, 14, $655-680$.

Jeekel, C.A.W. (1971) Nomenclator generum et familiarum Diplopodorum: a list of the genus and family-group names in the Class Diplopoda from the 10th edition of Linnaeus, 1758, to the end of 1957. Monografieën van de Nederlandse Entomologische Vereniging, 5, i-xii, 1-412.

Jeekel, C.A.W. (1985) The distribution of the Diplocheta and the "lost" continent pacifica (Diplopoda). Bijdragen tot de Dierkunde, 55, 100-112.

Jeekel, C.A.W. (2006) Millipedes from Australia, 17: A new genus and two new species of Cambalidae from New South Wales (Diplopoda, Spirostreptida). Myriapod Memoranda, 8, 65-73.

Jeekel, C.A.W. (2009) Millipedes from Australia, 24: Iulomorphidae from Victoria, with the description of two new species (Diplopoda, Spirostreptida). Myriapod Memoranda, 11, 31-41.

Jones, R.E. (1998) On the species of the genus Tuoba (Chilopoda: Geophilomorpha) in Australia, New Zealand, New Caledonia, Solomon Islands and New Britain. Records of the Western Australian Museum, 18, 333-346.

Kime, R.D. \& Golovatch, S.I. (2000) Trends in the ecological strategies and evolution of millipedes (Diplopoda). Biological Journal of the Linnean Society, 69, 333-349.

Koch, L.E. (1982) Taxonomy of the centipede genus Scolopendra laeta Haase (Chilopoda: Scolopendridae) in Australia. Zoological Journal of the Linnean Society, 76, 125-140.

Koch, L.E. (1983a) Revision of the Australian centipedes of the genus Cormocephalus Newport (Chilopoda: Scolopendridae: Scolopendrinae). Australian Journal of Zoology, 31, 799-833.

Koch, L.E. (1983b) A taxonomic study of the centipede genus Ethmostigmus Pocock (Chilopoda: Scolopendridae: Otostigminae) in Australia. Australian Journal of Zoology, 31, 835-849.

Koch, L.E. (1985a) A new genus and species of scolopendrid centipede from south-western Australia (Chilopoda: Scolopendridae: Scolopendrinae). Journal of Natural History, 18, 191-194.

Koch, L.E. (1985b) The taxonomy of Australian centipedes of the genus Rhysida Wood (Chilopoda: Scolopendridae: Otostigminae). Journal of Natural History, 19, 205-214.

Korsós, Z. \& Johns, P.M. (2009) Introduction to the taxonomy of Iulomorphidae of New Zealand, with descriptions of two new species of Eumastigonus Chamberlin, 1920 (Diplopoda: Spirostreptida: Epinannolenidea). Zootaxa, 2065, $1-24$.

Krantz, G.W. (1978) A manual of acarology. Oregon State University Book Stores, Corvallis.

Krantz, G.W. \& Walter, D.E. (2009) A manual of acarology. Lubbock, Texas Tech University Press.

Main, B.Y. (1991) Occurrence of the trapdoor spider genus Moggridgea in Australia with descriptions of two new species (Araneae: Mygalomorphae: Migidae). Journal of Natural History, 25, 383-397.

Main, B.Y. (1999) Biological anachronisms among trapdoor spiders reflect Australia's environmental changes since the Mesozoic. In: Ponder, W. \& Lunney, D. (Eds.) The other 99\%. The conservation and biodiversity of invertebrates. Transactions of the Royal Zoological Society of New South Wales, Mossman, pp. 236-245. 
Mauriès, J.-P. (1987) Cambalides nouveaux et peu connus d'Asie, d'Amérique et d'Océanie. II. Pseudonannolenidae, Choctellidae (Myriapoda, Diplopoda). Bulletin du Muséum National d'Histoire Naturelle, Paris, serie 4, 9A(1), 169-199.

Mesibov, R. (1994) Faunal breaks in Tasmania and their significance for invertebrate conservation. Memoirs of the Queensland Museum, 36, 133-136.

Mesibov, R. (2003a) Lineage mosaics in millipedes. African Invertebrates, 44, 203-212.

Mesibov, R. (2003b) The millipede genus Gasterogramma (Diplopoda: Polydesmida: Dalodesmidae) in Tasmania, Australia, with descriptions of seven new species. Memoirs of Museum Victoria, 60, 207-219.

Mesibov, R. (2003c) A new genus of Tasmanian millipedes (Diplopoda, Polydesmida, Dalodesmidae) with unusual spiracles and a mosaic distribution. Memoirs of Museum Victoria, 60, 197-206.

Mesibov, R. (2009) Millipedes of Australia. http://www.qvmag.tas.gov.au/zoology/millipedes/index.html. Date of access, 25 October 2009. Queen Victoria Museum, Launceston

Mesibov, R., Bonham, K.J., Doran, N., Meggs, J., Munks, S., Otley, H. \& Richards, K. (2002) Single-species sampling in Tasmania: an inefficient approach to invertebrate conservation? Invertebrate Systematics, 16, 655-663.

Moir, M.L., Brennan, K.E.C. \& Harvey, M.S. (2009) Diversity, endemism and species turnover of millipedes within the south-western Australia global biodiversity hotspot Journal of Biogeography, 36, 1958-1971.

Moritz, C. (2002) Strategies to protect biological diversity and the evolutionary processes that sustain it. Systematic Biology, 51, 238-254.

Myers, N., Mittermeier, R.A., Mittermeier, C.G., Fonseca, G.A.B.d. \& Kent, J. (2000) Biodiversity hotspots for conservation priorities. Nature, 403, 853-858.

Ponder, W.F. \& Colgan, D.J. (2002) What makes a narrow-range taxon? - Insights from Australian freshwater snails. Invertebrate Systematics, 16, 571-582.

Reid, A. (2002) Western Australian Onychophora (Peripatopsidae): a new genus, Kumbadjena, for a southern speciescomplex. Records of the Western Australian Museum, 21, 129-155.

Scheller, U. (1961) A review of the Australian Symphyla (Myriapoda). Australian Journal of Zoology, 9, $140-171$.

Shelley, R.M. (2007) Taxonomy of extant Diplopoda (millipeds) in the modern era: perspectives for future advancements and onservations on the global diplopod community (Arthropoda: Diplopoda). Zootaxa, 1668, 343-362.

Shelley, R.M. \& Whitehead, D.R. (1986) A reconsideration of the milliped genus Sigmoria, with a revision of Deltotaria and an analysis of the genera in the tribe Aphelorini (Polydesmida: Xystodesmidae). Memoirs of the American Entomological Society, 35, 1-223.

Sierwald, P. \& Bond, J.E. (2007) Current status of the myriapod class Diplopoda (millipedes): Taxonomic diversity and phylogeny. Annual Review of Entomology, 52, 401-420.

Verhoeff, K.W. (1924) Results of Dr. E. Mjöberg's Swedish Scientific Expeditions to Australia 1910-1913. 34. Myriapoda: Diplopoda. Arkiv för Zoologi, 16, 1-142.

Wardell-Johnson, G. \& Roberts, J.R. (1996) Morphological variation in the Geocrinia rosea (Anura: Myobatrachidae) complex in southwestern Australia. In: Hopper, S.D., Chappill, J.A., Harvey, M.S. \& George, A.S. (Eds.) Gondwanan Heritage: Past, Present and Future of the Western Australian Biota Surrey Beatty \& Sons, Chipping Norton, pp. 172-178.

Wilson, H.M. \& Anderson, L.I. (2004) Morphology and taxonomy of Paleozoic millipedes (Diplopoda: Chilognatha: Archipolypoda) from Scotland. Journal of Paleontology, 78, 169-184. 

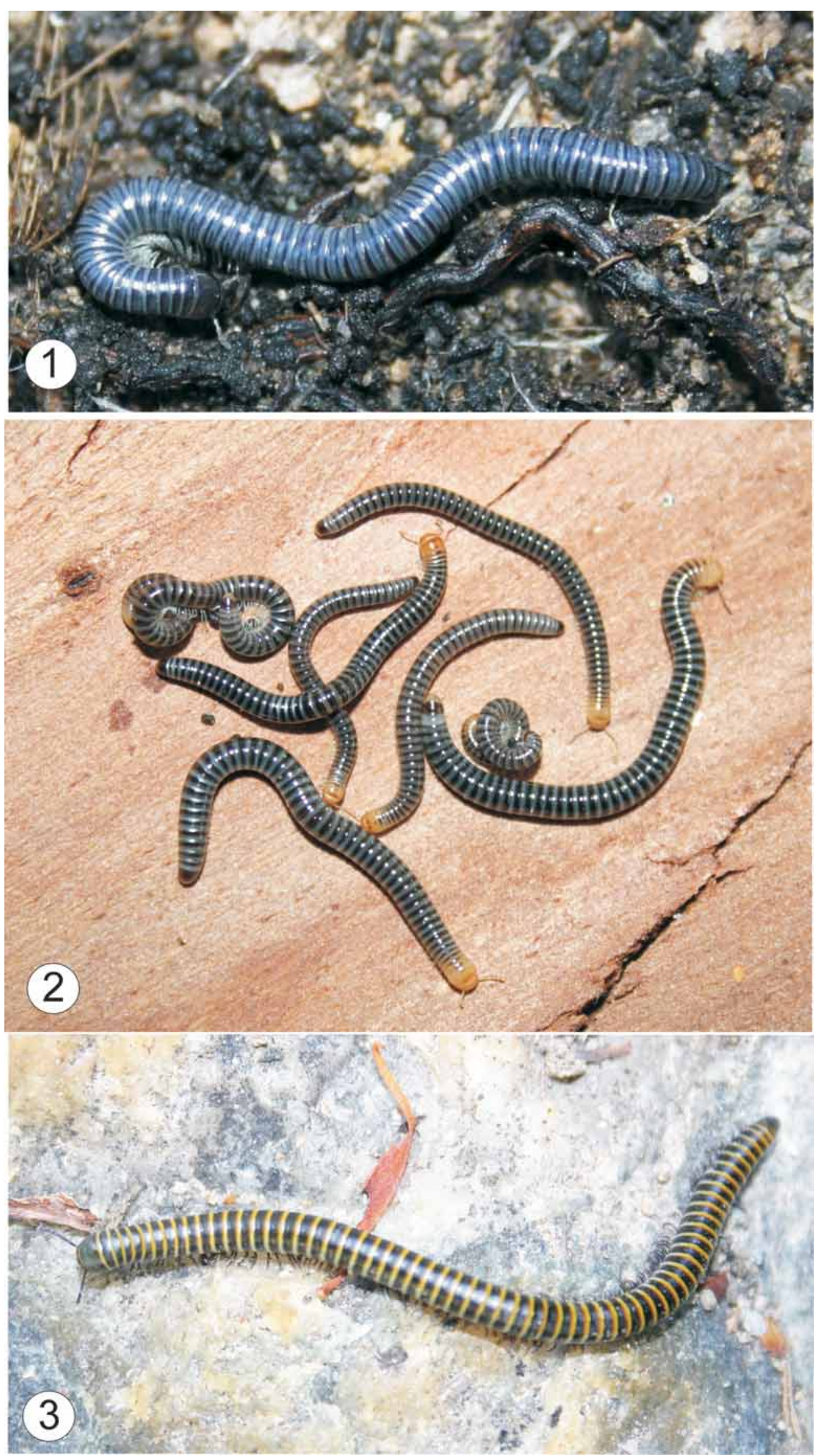

FIGURES 1-3. 1: Atelomastix montana, sp. nov., from Stirling Range National Park, Western Australia (WAM T54251); 2: Atelomastix rubricephala, sp. nov., from Two Peoples Bay Nature Reserve, Western Australia (WAM T69939); 3: Atelomastix tigrina, sp. nov., from Stirling Range National Park, Western Australia (WAM T74312). 

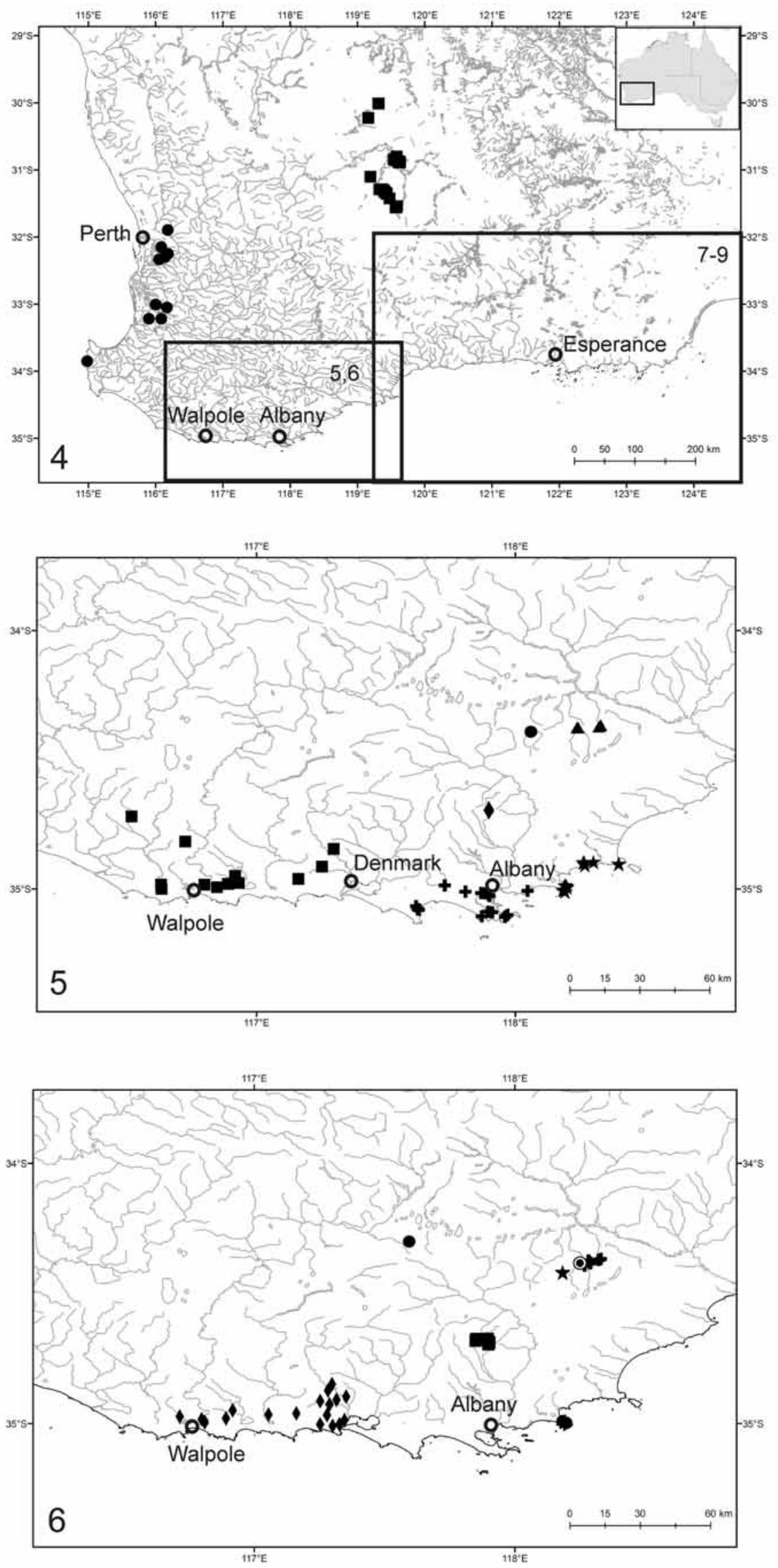

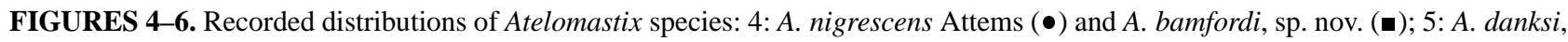

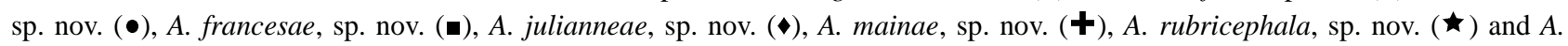

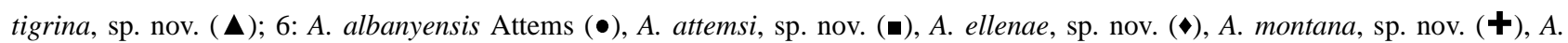
poustiei, sp. nov. ( ) and A. tumula, sp. nov. (๑). 

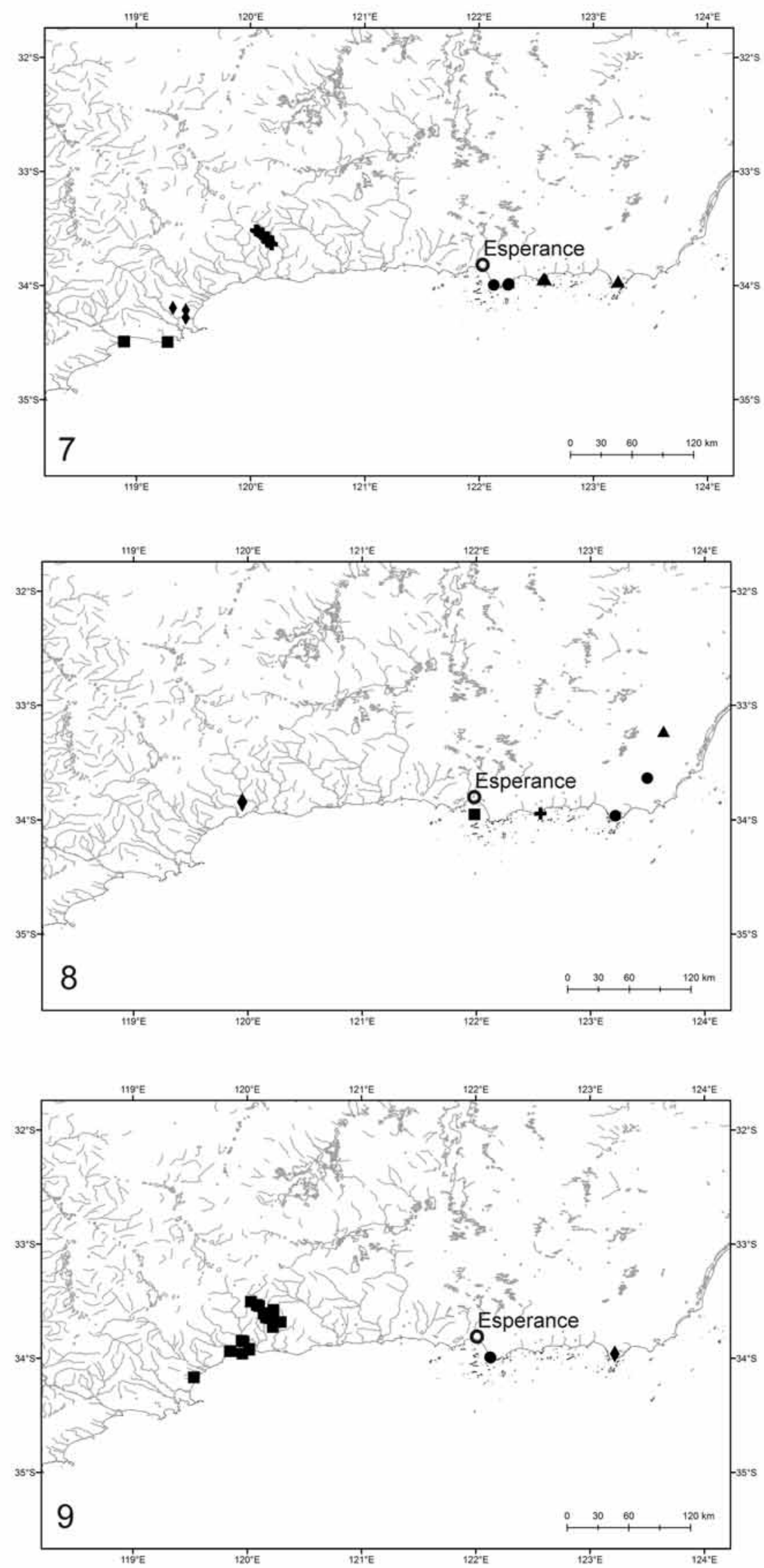

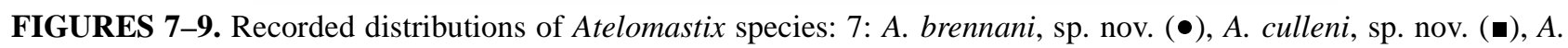

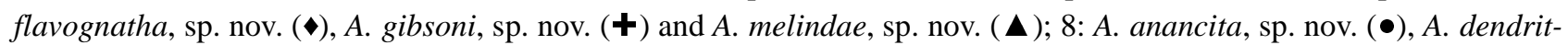

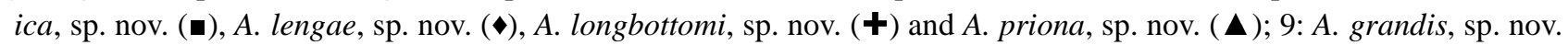
$(\bullet)$, A. psittacina, sp. nov. (•) and A. sarahae, sp. nov. (४). 

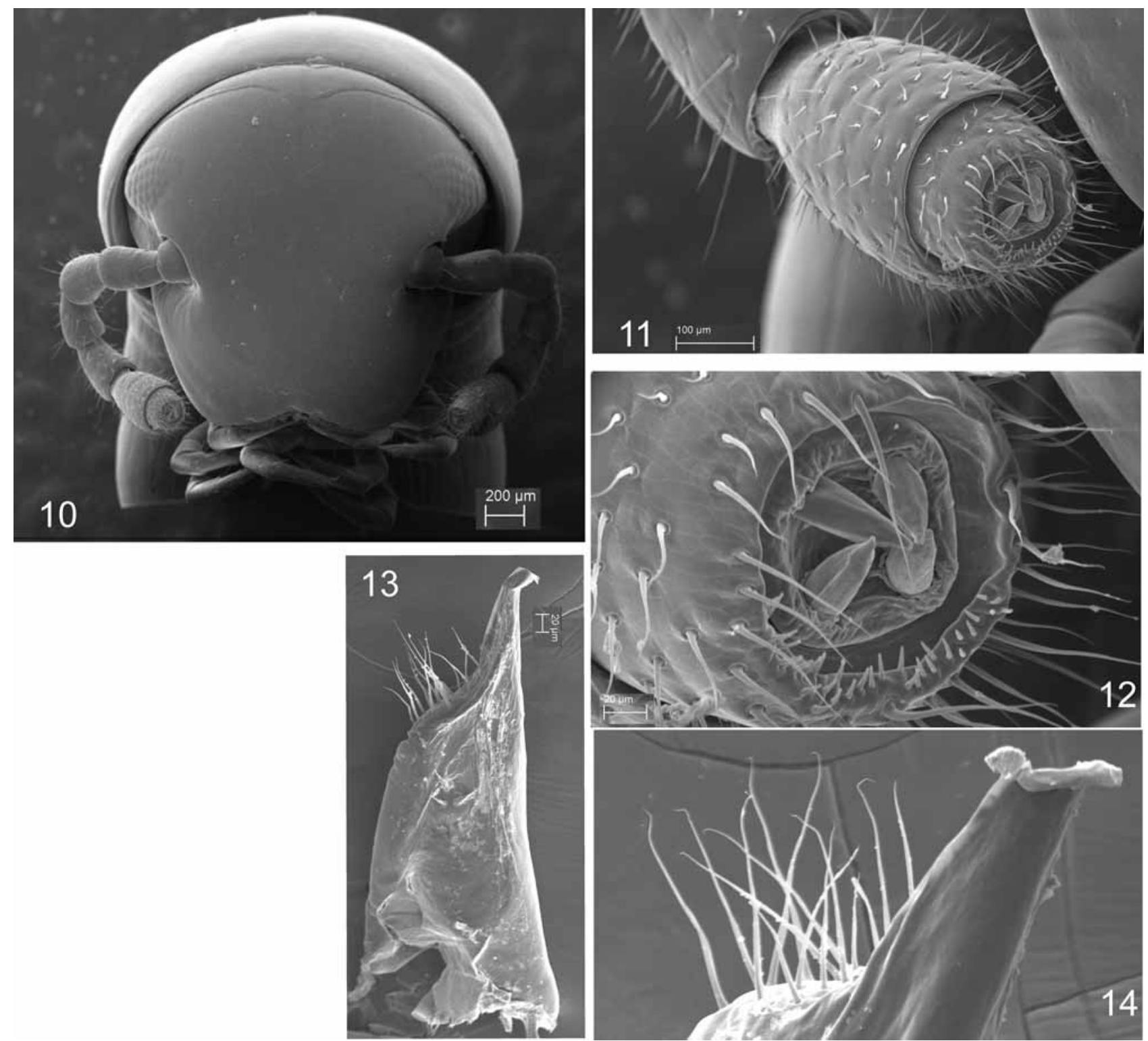

FIGURES 10-14. Atelomastix nigrescens Attems, male from W. of Collie, Western Australia (WAM T83392), scanning electron micrographs: 10: head, anterior aspect; 11: distal antennal segment; 12: detail of terminal antennal segments and sensory cones; 13: left posterior gonopod, anterior aspect; 14: detail of same. 


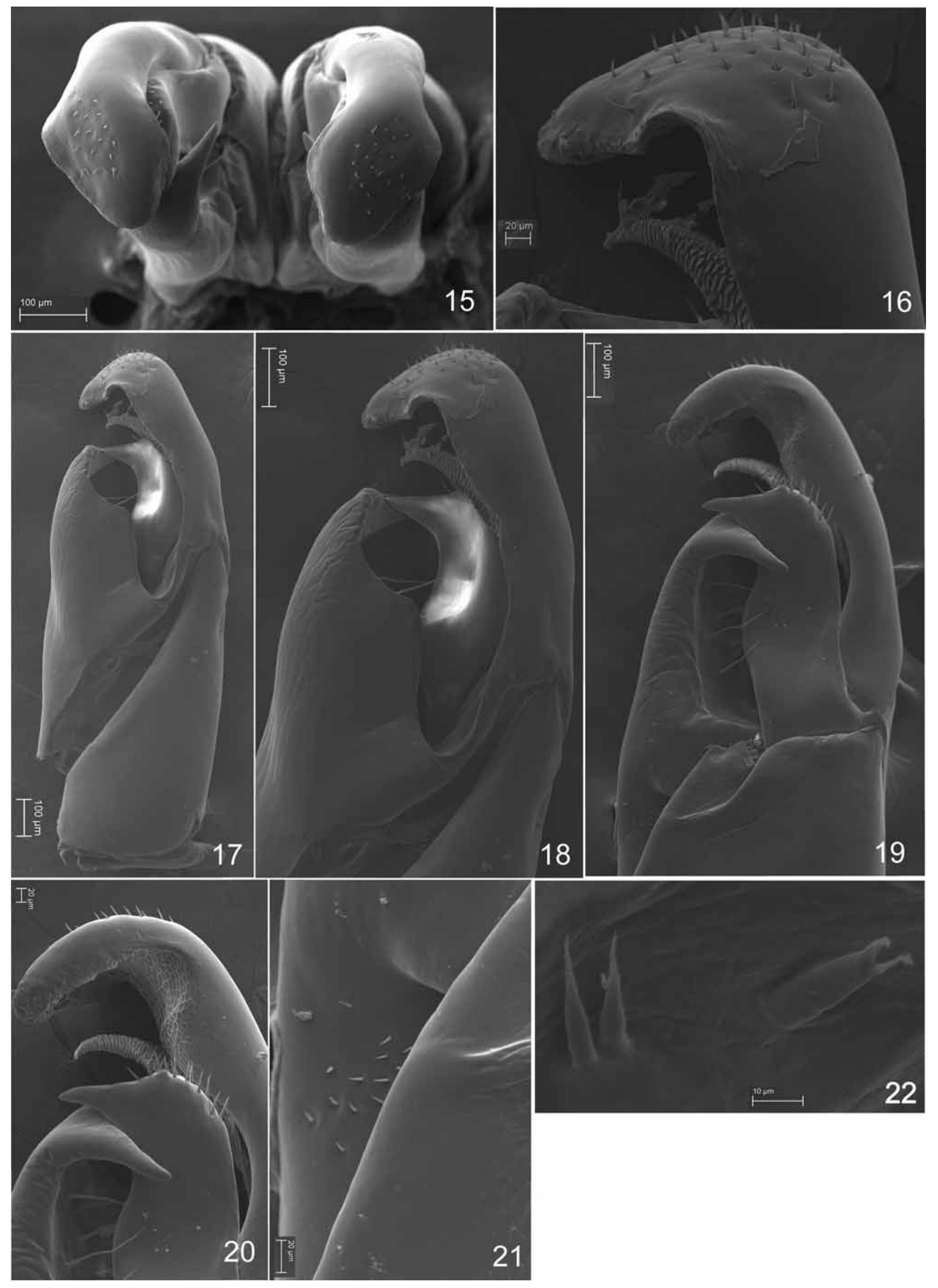


FIGURES 15-22. Atelomastix nigrescens Attems, male from W. of Collie, Western Australia (WAM T83392), scanning electron micrographs, anterior gonopods: 15: dorsal view of both gonopods; 16: distal end of left gonopod, externolateral aspect; 17: entire left gonopod, externolateral aspect; 18: distal half of left gonopod, exterolateral aspect; 19: distal half of right gonopod, internolateral aspect; 20: distal end of right gonopod; 21: group of short setae positioned sub-basally on sclerite $c$, internolateral aspect of right gonopod; 22: detail of setae-like structures on externolateral aspect of left gonopod.
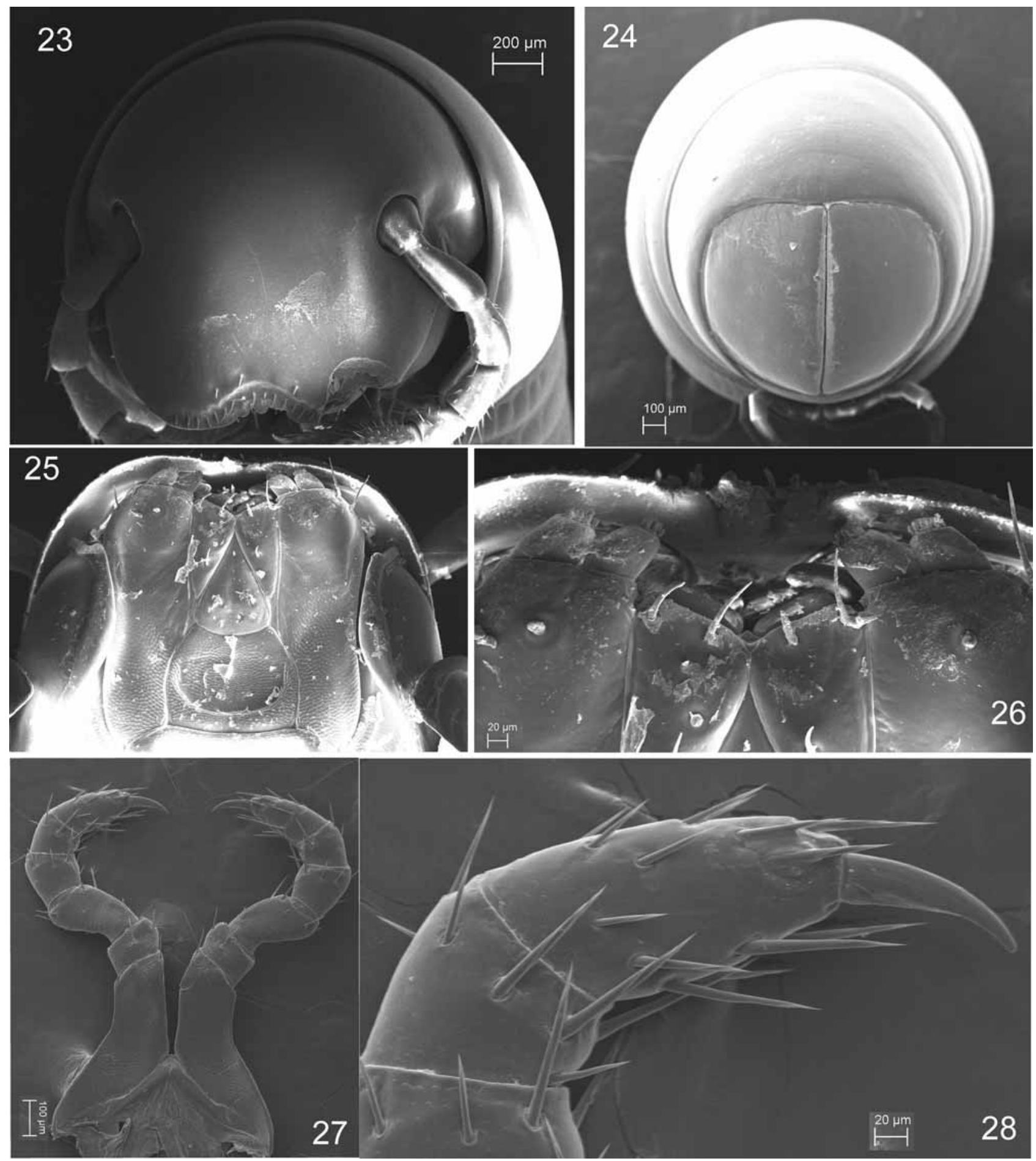

FIGURES 23-28. Atelomastix rubricephala, sp. nov., male and female from Waychinicup Nature Reserve, Western Australia (WAM T78633), scanning electron micrographs: 23: head, female, anterior view; 24: anal somite, female, posterior view; 25: Gnathochilarium, male, ventral view; 26: distal edge of gnathochilarium, male, ventral view; 27: second leg pair, male; 28: tip of leg 2, male. 


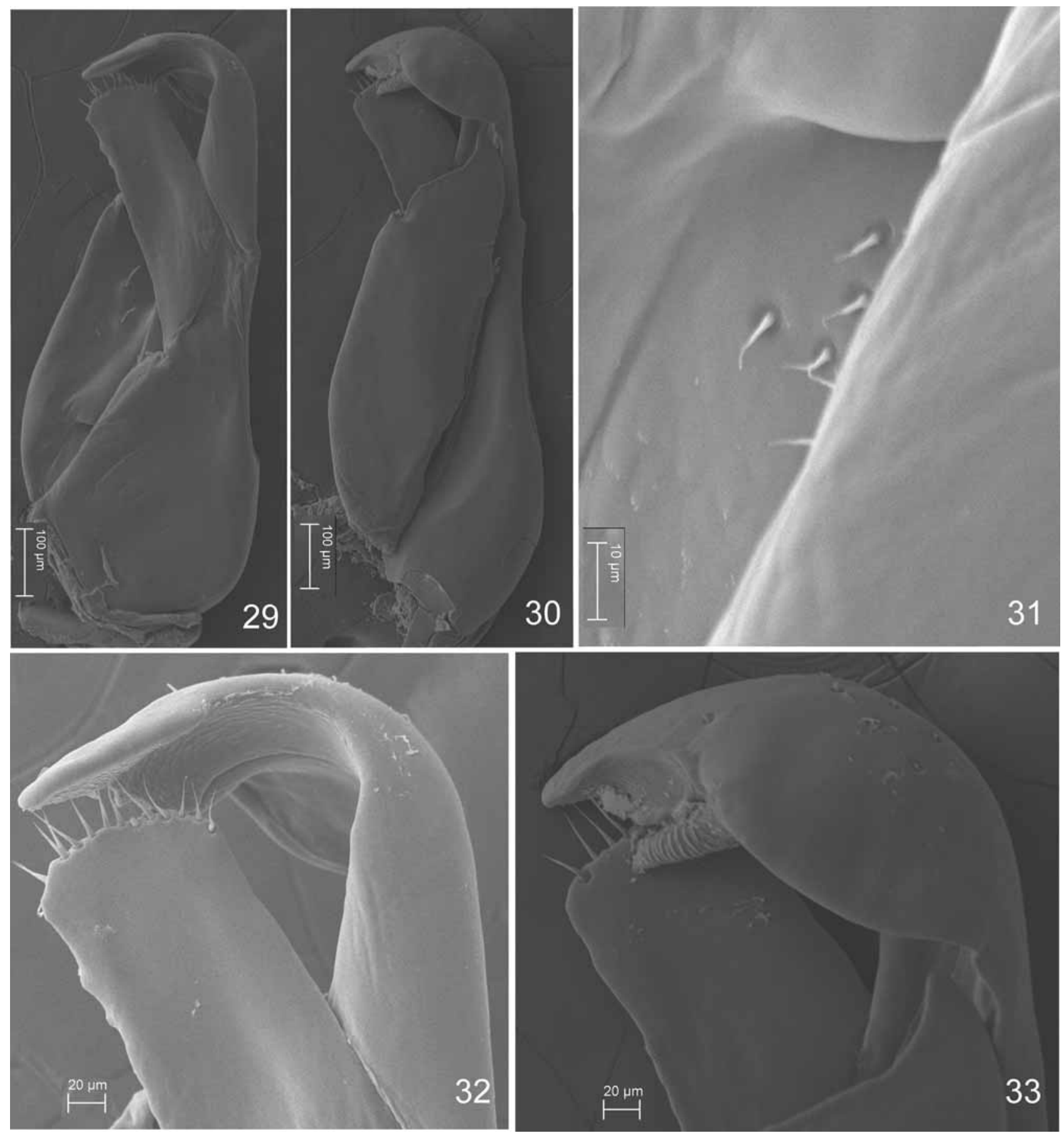

FIGURES 29-33. Atelomastix rubricephala, sp. nov., male from Waychinicup Nature Reserve, Western Australia (WAM T78633), scanning electron micrographs, anterior gonopods: 29: entire right gonopod, internolateral aspect; 30: entire left gonopod, externolateral aspect; 31: group of short setae positioned sub-basally on sclerite $c$, internolateral aspect of right gonopod; 32: distal tip of right gonopod, internolateral aspect; 33: distal tip of left gonopod, externolateral aspect. 


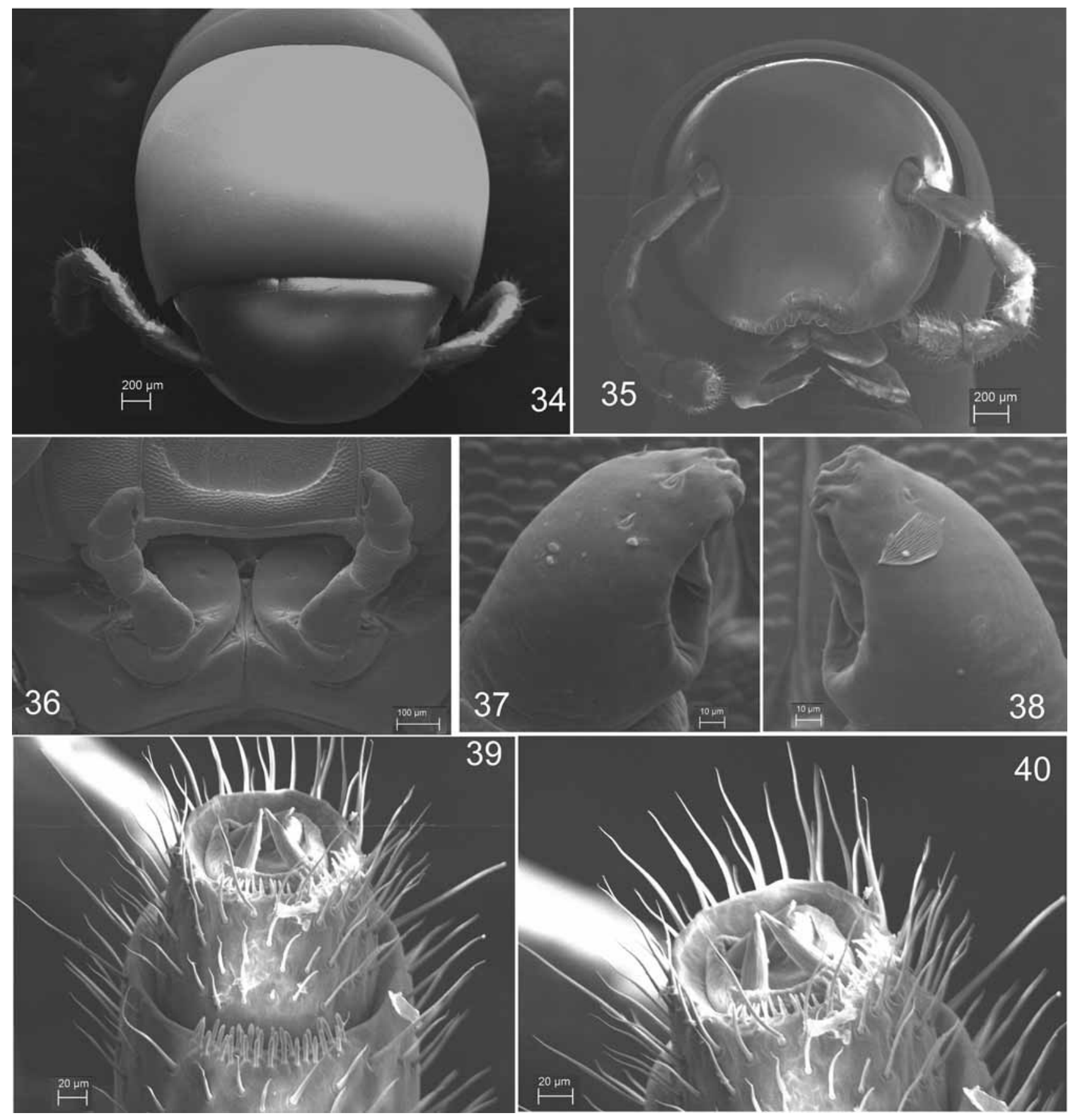

FIGURES 34-40. Atelomastix danksi, sp. nov., male and female paratypes from Toolbrunup Peak, Stirling Range National Park, Western Australia (WAM T70203), scanning electron micrographs: 34: head and collum, female, dorsal aspect; 35: head, male, anterior aspect; 36: first pair of legs, male, ventral aspect; 37: tip of right leg I, male; 38: tip of left leg I, male; 39: tip of antenna, male, ventral aspect; 40: detail of same. 

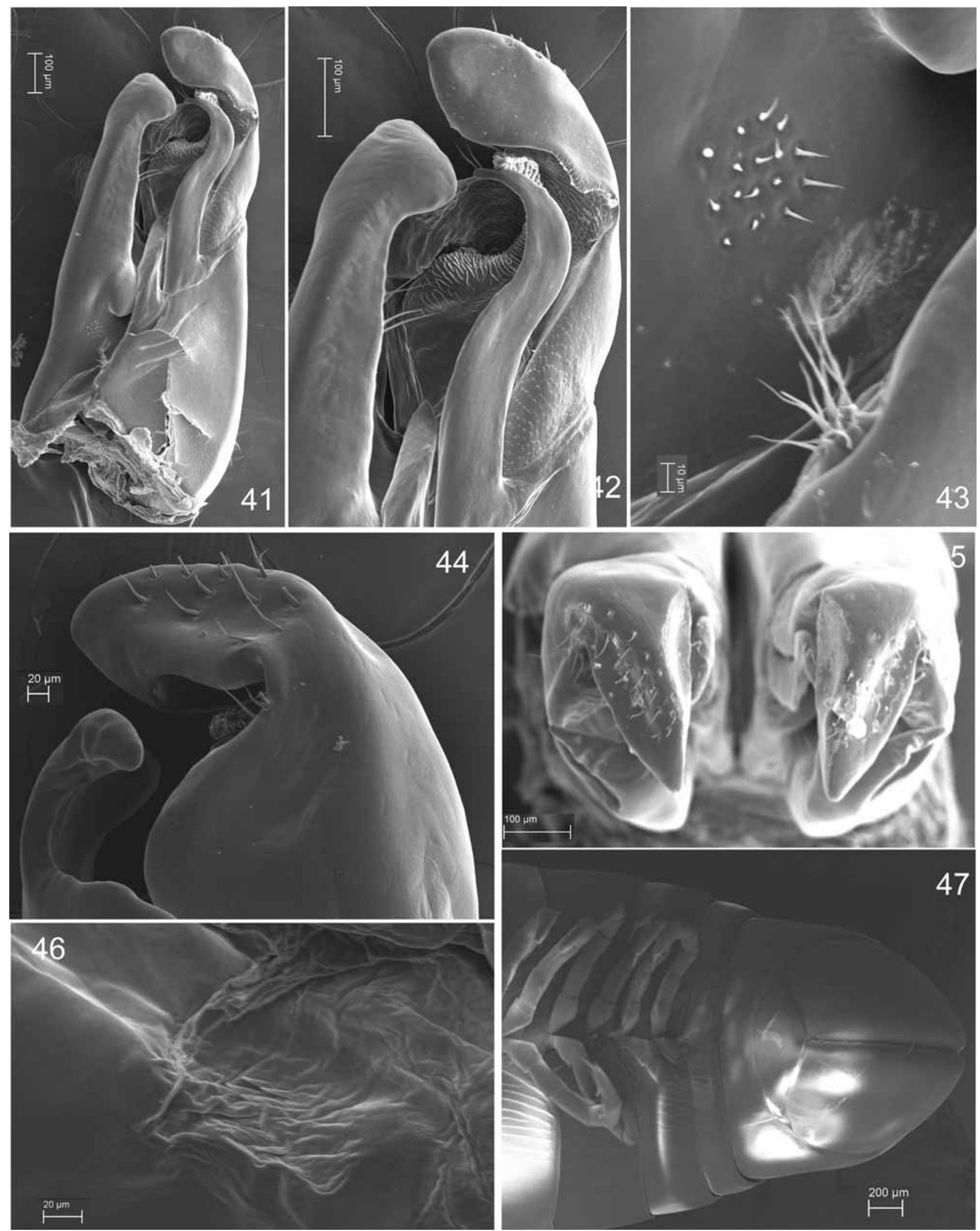

FIGURES 41-47. Atelomastix danksi, sp. nov., male and female paratypes from Toolbrunup Peak, Stirling Range National Park, Western Australia (WAM T70203), scanning electron micrographs: 41: entire right anterior gonopod, male, internolateral aspect; 42 : tip of right anterior gonopod, male, internolateral aspect; 43: group of short setae positioned sub-basally on sclerite $c$, and tuft of fine, elongate setae positioned on sub-basal edge of sclerite $b$, internolateral aspect of right gonopod; 44: tip of left anterior gonopod, male, externolateral aspect; 45: both gonopods, dorsal aspect; 46: detail of soft tissue and spines at base of gonopod; 47: posterior trunk segments, female, ventral aspect. 

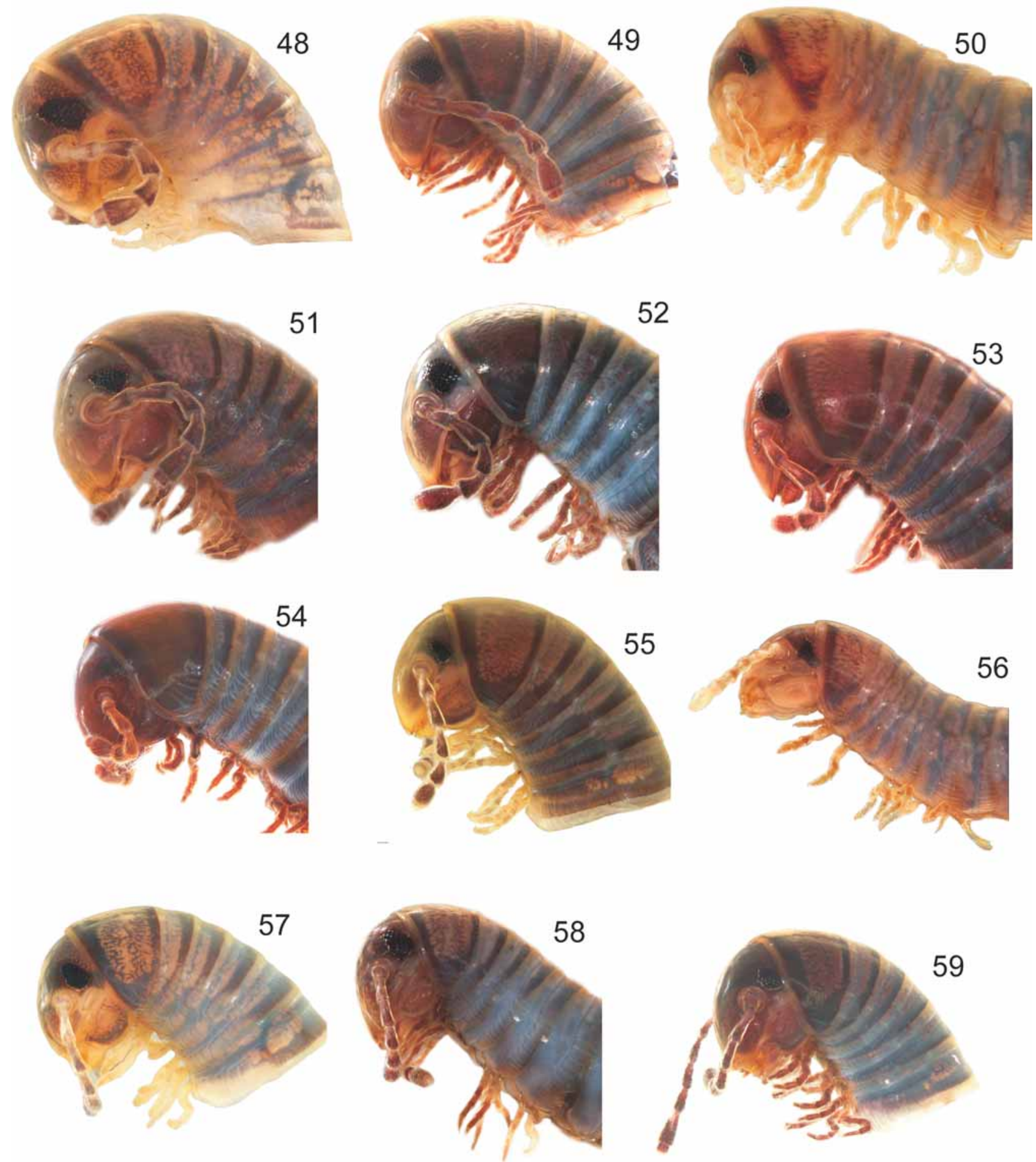

FIGURES 48-59. Lateral view of head: 48: Atelomastix albanyensis Attems, male from Two Peoples Bay Nature Reserve, Western Australia (WAM T76043); 49: A. anancita, sp. nov., male holotype from Cape Arid National Park, Western Australia (WAM T83177); 50: A. attemsi, sp. nov., male paratype from Millinup Pass, Porongurup Range National Park, Western Australia (WAM T69763); 51: A. bamfordi, sp. nov., male paratype from Mount Jackson, Western Australia (WAM T86852); 52: A. brennani, sp. nov., male holotype from Mount Le Grand, Le Grand National Park, Western Australia (WAM T83222); 53: A. culleni, sp. nov., male paratype from Mount Groper, Western Australia (WAM T78621); 54: A. danksi, sp. nov., male paratype from Toolbrunup Peak, Stirling Range National Park, Western Australia (WAM T70203); 55: A. dendritica, sp. nov., male holotype from Woody Island, Recherche Archipelago, Western Australia (WAM T47933); 56: A. ellenae, sp. nov., male paratype from Walpole, Valley of the Giants Road, Western Australia (WAM T69668); 57: A. flavognatha, sp. nov., male holotype from Quaalup Homestead, Western Australia (WAM T73955); 58: A. francesae, sp. nov., male holotype from near Tree Top Walk, Walpole, Western Australia (WAM T47953); 59: A. gibsoni, sp. nov., male holotype from Ravensthorpe Ranges, Western Australia (WAM T83220). 

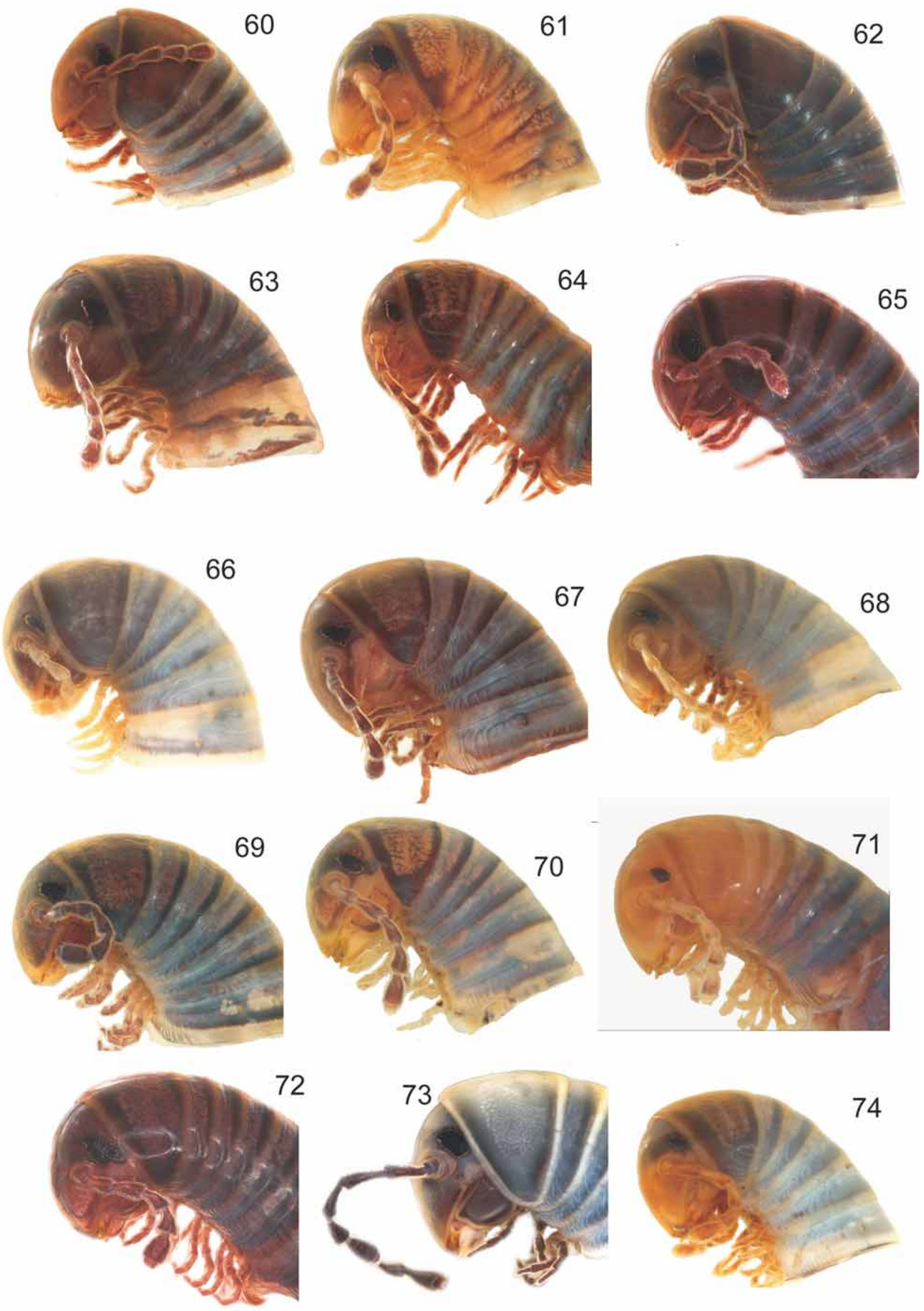
FIGURES 60-74. Lateral view of head: 60: Atelomastix grandis, sp. nov., male holotype from Le Grand National Park, Western Australia (WAM T83221); 61: A. julianneae, sp. nov., male holotype from Porongurup Range National Park, Western Australia (WAM T69805); 62: A. lengae, sp. nov., male holotype from Fitzgerald River National Park, Western Australia (WAM T80799); 63: A. longbottomi, sp. nov., male holotype from Duke of Orleans Bay, Western Australia (WAM T82780); 64: A. mainae, sp. nov., male paratype from Albany, Mount Clarence, Western Australia (WAM T69596); 65: A. melindae, sp. nov., male paratype from Mount Arid, Cape Arid National Park, Western Australia (WAM T80673); 66: A. montana, sp. nov., male holotype from Pyungoorup Peak, Stirling Range National Park, Western Australia (WAM T72777); 67: A. nigrescens Attems, male from SW. of Boddington, Western Australia (WAM T85869); 68: A. poustiei, sp. nov., male holotype from Stirling Range National Park, Western Australia (WAM T72775); 69: A. priona, sp. nov., male holotype from Kangawarie, Western Australia (WAM T72121); 70: A. psittacina, sp. nov., male holotype from Fitzgerald River National Park, Western Australia (WAM T73956); 71: A. rubricephala, sp. nov., male holotype from S. of Mount Manypeaks, Western Australia (WAM T71606); 72: A. sarahae, sp. nov., Waychinicup Nature Reserve, Western Australia (WAM T80674); 73: A. tigrina, sp. nov., male holotype from The Cascades, Stirling Range National Park, Western Australia (WAM T74312); 74: A. tumula, sp. nov., male holotype from Bluff Knoll Walking Trail, Stirling Range National Park, Western Australia (WAM T74317). 

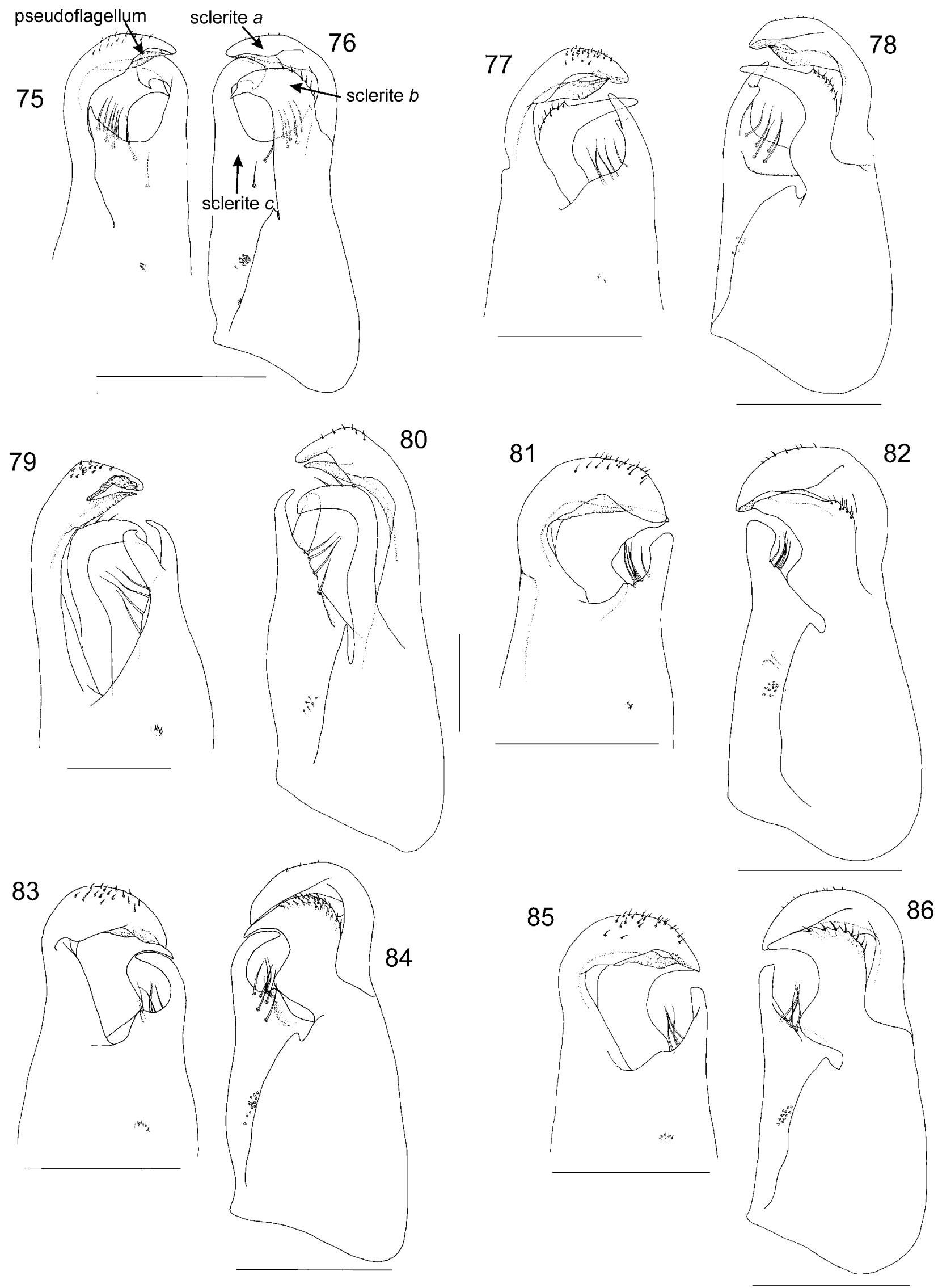
FIGURES 75-86. 75, 76: Atelomastix albanyensis Attems, male from Two Peoples Bay Nature Reserve, Western Australia (WAM T76043), right anterior gonopod: 75: externolateral aspect; 76: internolateral aspect. 77, 78: Atelomastix anancita, sp. nov., male holotype from Cape Arid National Park, Western Australia (WAM T83177), right anterior gonopod: 77: externolateral aspect; 78: internolateral aspect. 79, 80: Atelomastix attemsi, sp. nov., male holotype from Porongurup Range National Park, Western Australia (WAM T47956), right anterior gonopod: 79: externolateral aspect; 80: internolateral aspect. 81, 82: Atelomastix bamfordi, sp. nov., male holotype from Mount Jackson area, Western Australia (WAM T86853), right anterior gonopod: 81: externolateral aspect; 82: internolateral aspect. 83, 84: Atelomastix brennani, sp. nov., male holotype from Mount Le Grand, Le Grand National Park, Western Australia (WAM T83222), right anterior gonopod: 83: externolateral aspect; 84: internolateral aspect. 85, 86: Atelomastix culleni, sp. nov., male holotype from Bremer Bay, Western Australia (WAM T83163), right anterior gonopod: 85: externolateral aspect; 86: internolateral aspect. Scale lines $=0.5 \mathrm{~mm}$ (Figs. 75-78, 81-86), $0.2 \mathrm{~mm}$ (Figs. 79-80). 


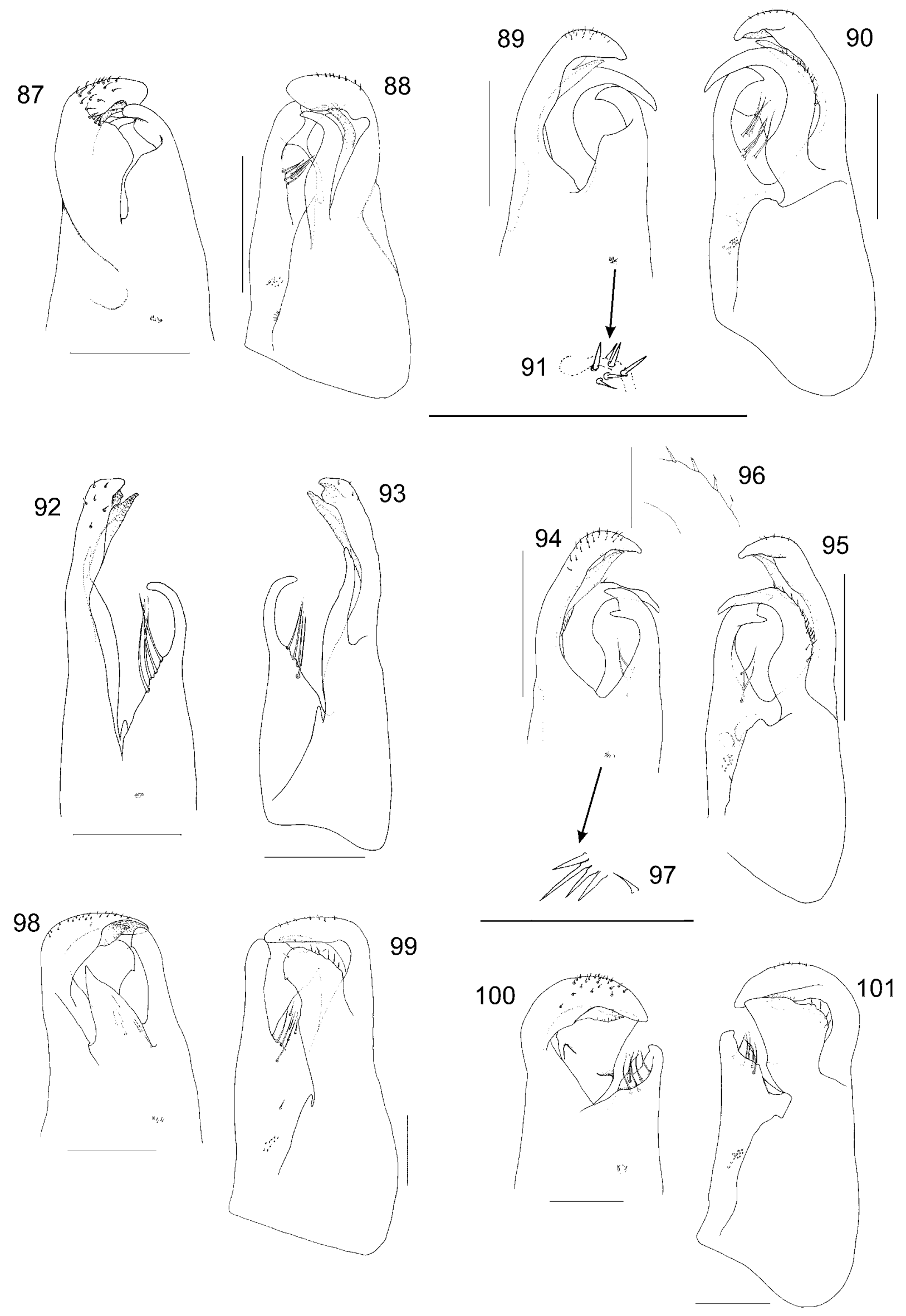


FIGURES 87-101. 87, 88: Atelomastix danksi, sp. nov., male holotype from Toolbrunup Peak, Stirling Range National Park, Western Australia (WAM T47957), right anterior gonopod: 87: externolateral aspect; 88: internolateral aspect. 8991: Atelomastix dendritica, sp. nov., male holotype from Woody Island, Recherche Archipelago, Western Australia (WAM T47933), right anterior gonopod: 89: externolateral aspect; 90: internolateral aspect; 91: detail of externolateral setae. 92-93: Atelomastix ellenae, sp. nov., male holotype from near Walpole, Western Australia (WAM T47954), right anterior gonopod: 92: externolateral aspect; 93: internolateral aspect. 94-97: Atelomastix flavognatha, sp. nov., male holotype from Quaalup Homestead, Western Australia (WAM T73955), right anterior gonopod: 94: externolateral aspect; 95: internolateral aspect; 96: detail of setae on tip of sclerite $b$; 97: detail of externolateral setae. 98, 99: Atelomastix francesae, sp. nov., male holotype from near Walpole, Western Australia (WAM T47953), right anterior gonopod: 98: externolateral aspect; 99: internolateral aspect. 100, 101: Atelomastix gibsoni, sp. nov., male holotype from Ravensthorpe Ranges, Western Australia (WAM T83220), right anterior gonopod: 100: externolateral aspect; 101: internolateral aspect. Scale lines = $0.5 \mathrm{~mm}$ (Figs. 87-90, 94, 95), 0.2 mm (Figs. 92-93, 98-101), 0.1 mm (Figs. 96, 97). 

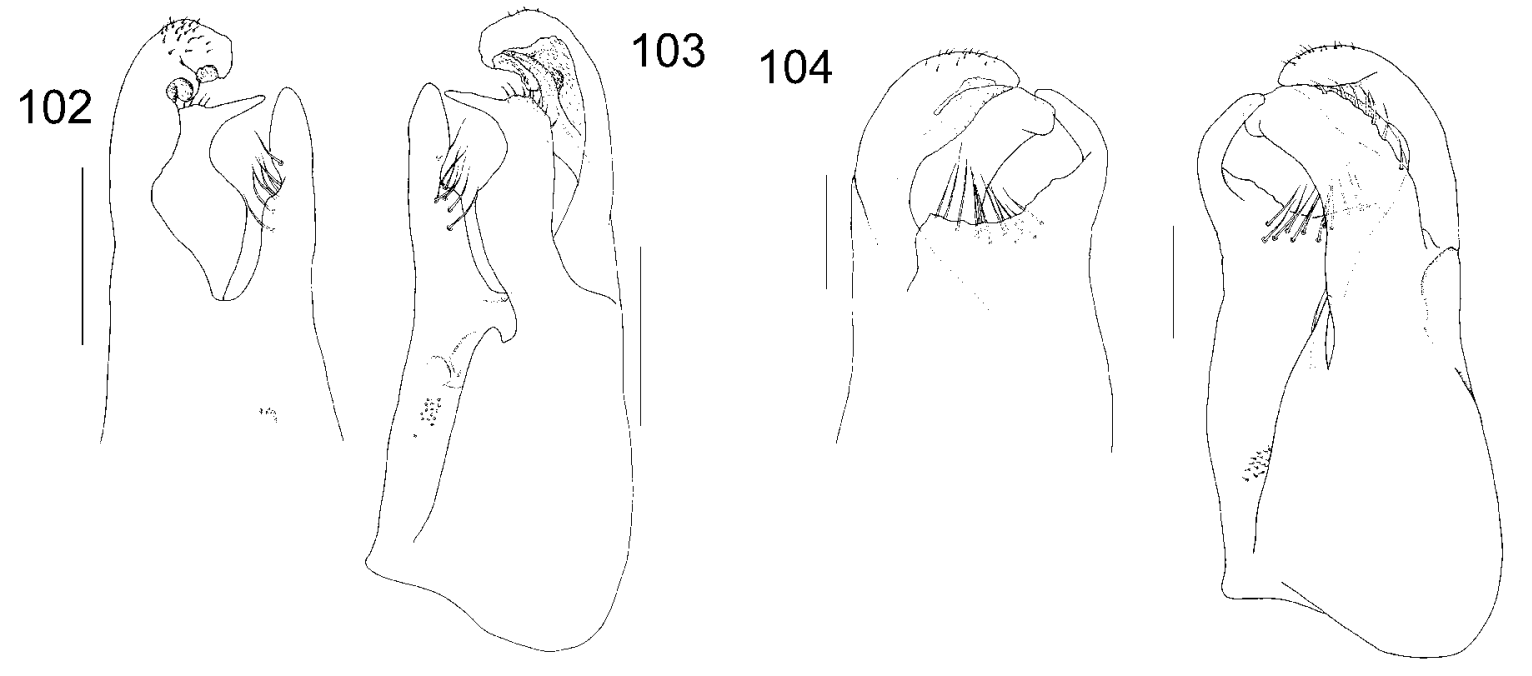

105
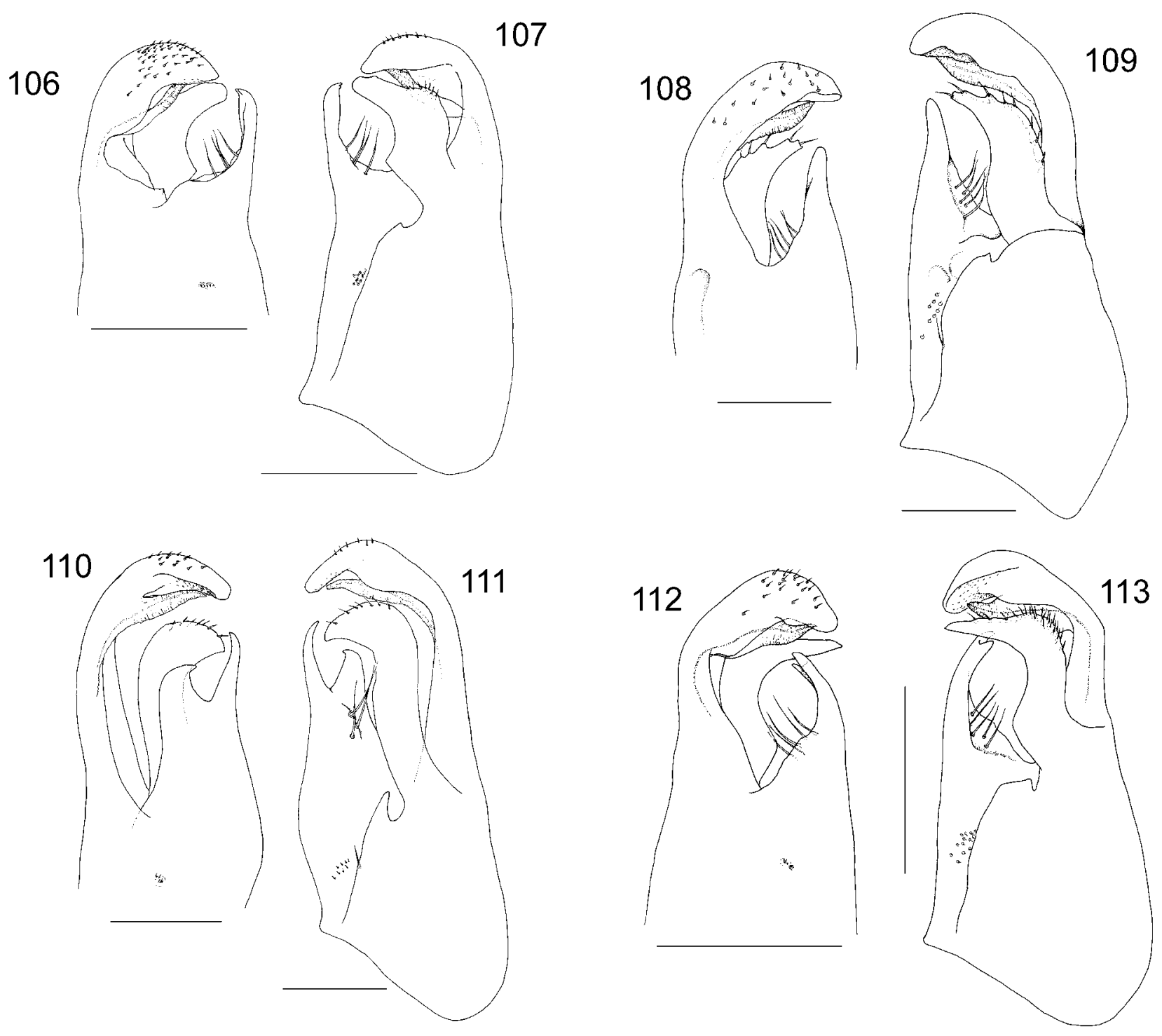
FIGURES 102-113. 102, 103: Atelomastix grandis, sp. nov., male holotype from Le Grand National Park, Western Australia (WAM T83221), right anterior gonopod: 102: externolateral aspect; 103: internolateral aspect. 104, 105: Atelomastix julianneae, sp. nov., male holotype from Porongurup Range National Park, Western Australia (WAM T69805), right anterior gonopod: 104: externolateral aspect; 105: internolateral aspect. 106, 107: Atelomastix lengae, sp. nov., male holotype from Fitzgerald River National Park, Western Australia (WAM T80799), right anterior gonopod: 106: externolateral aspect; 107: internolateral aspect. 108, 109. Atelomastix longbottomi, sp. nov., male holotype from Duke of Orleans Bay, Western Australia (WAM T82780), right anterior gonopod: 108: externolateral aspect; 109: internolateral aspect. 110, 111: Atelomastix mainae, sp. nov., male holotype from Albany, Western Australia (WAM T47955), right anterior gonopod: 110: externolateral aspect; 111: internolateral aspect. 112, 113: Atelomastix melindae, sp. nov., male holotype from Cape Arid National Park, Western Australia (WAM T83248), right anterior gonopod: 112: externolateral aspect; 113: internolateral aspect. Scale lines $=0.5 \mathrm{~mm}$ (Figs. 102, 103, 106, 107, 112, 113), 0.2 mm (Figs. 104, 105, 108-111). 

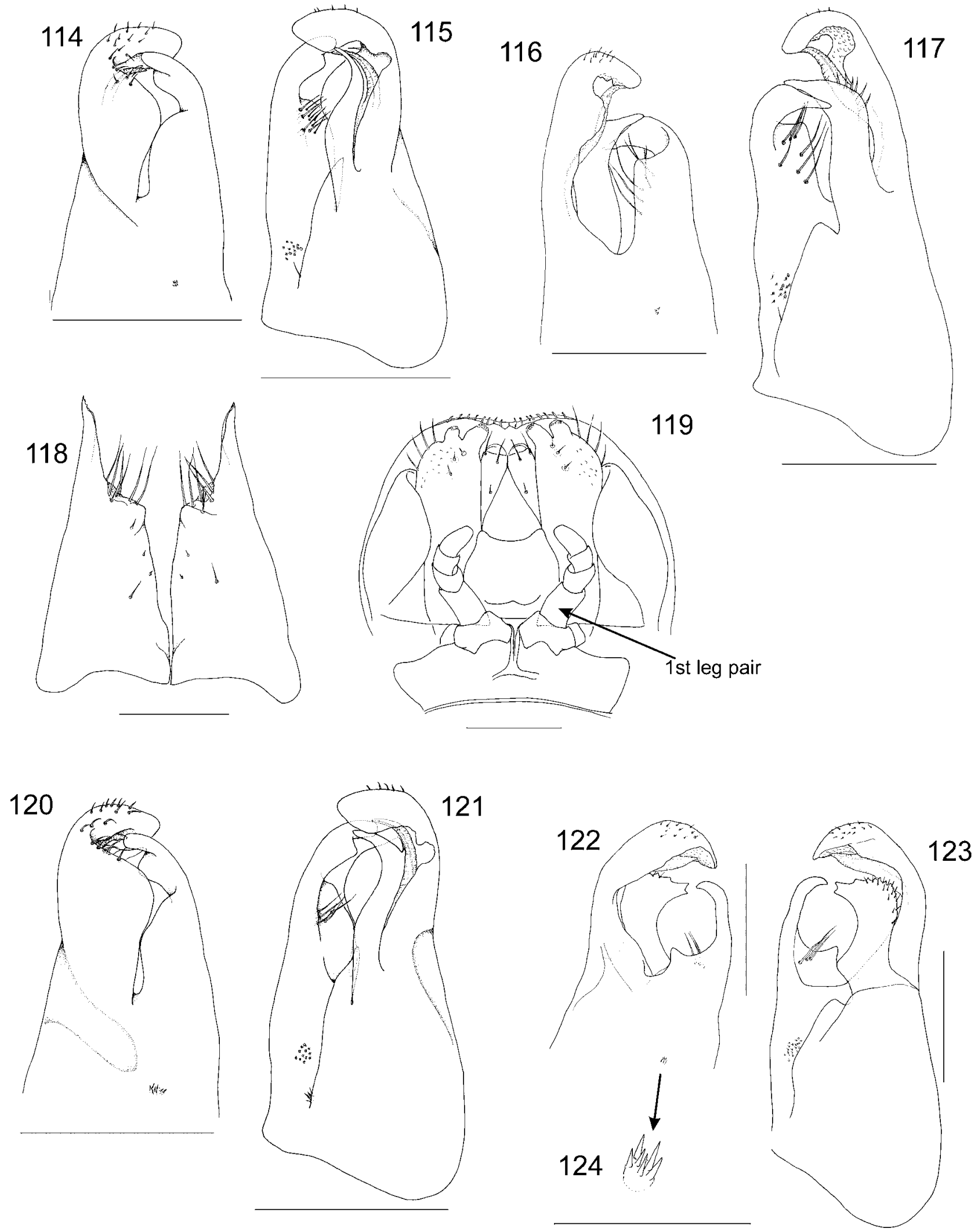
FIGURES 114-124. 114, 115: Atelomastix montana, sp. nov., male holotype from Stirling Range National Park, Western Australia (WAM T69804), right anterior gonopod: 114: externolateral aspect; 115: internolateral aspect. 116-119: Atelomastix nigrescens Attems, male syntype from Jarrahdale, Western Australia (ZMB 5163): 116-117: right anterior gonopod: 116: externolateral aspect; 117: internolateral aspect; 118: posterior gonopods, anterior aspect; 119: gnathochilarium, ventral aspect. 120, 121. Atelomastix poustiei, sp. nov., male holotype from Wedge Hill, Stirling Range National Park, Western Australia (WAM T72775), right anterior gonopod: 120: externolateral aspect; 121: internolateral aspect. 122-124: Atelomastix priona, sp. nov., male holotype from Kangawarie, Western Australia (WAM T72121), right anterior gonopod: 122: externolateral aspect; 123: internolateral aspect; 124: detail of externolateral setae. Scale lines = 0.5 mm (Figs. 114-117, 119-123), 0.2 mm (Fig. 118), 0.1 mm (Fig. 124) 
125

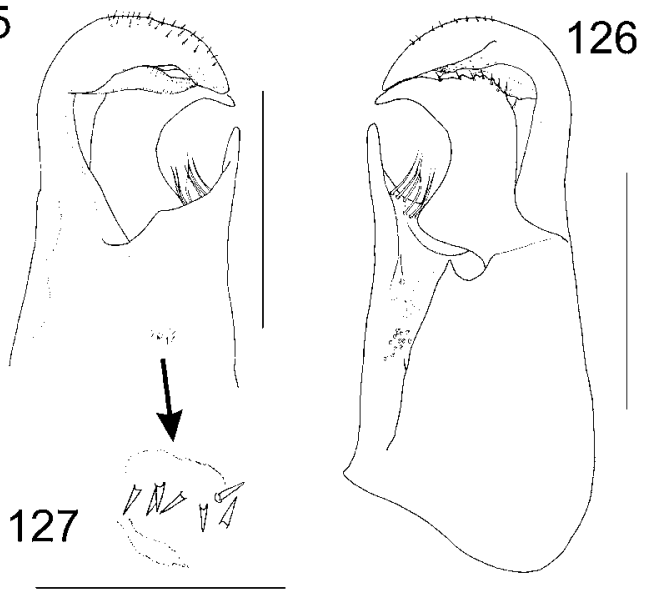

130
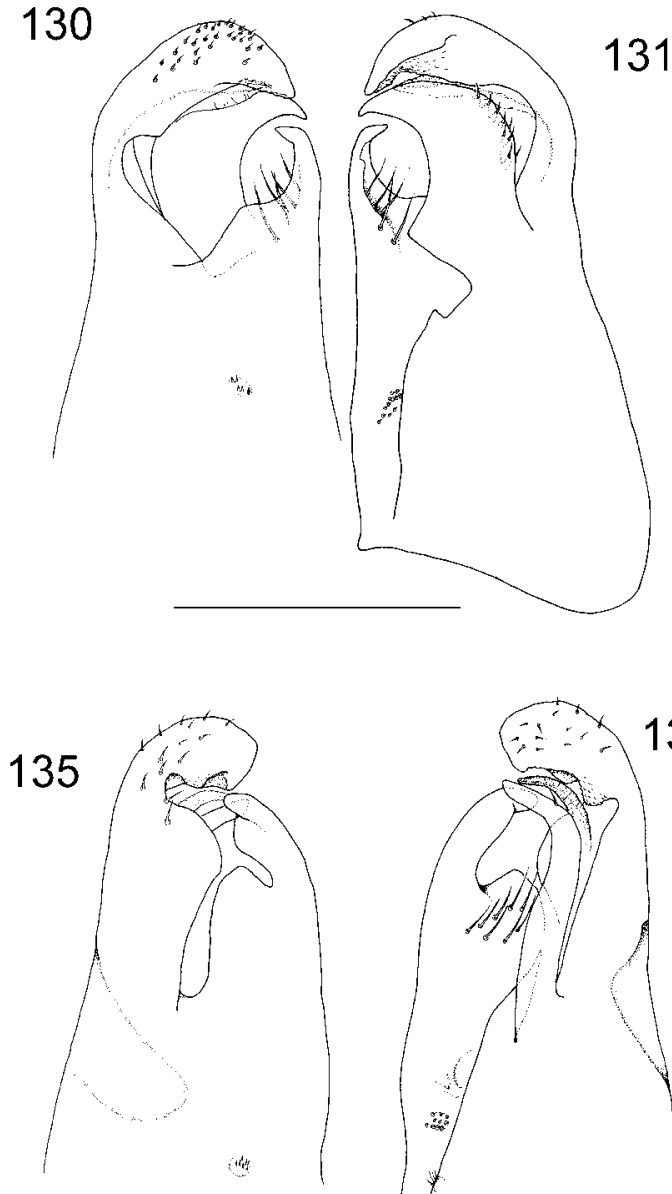

$\therefore \therefore 136$

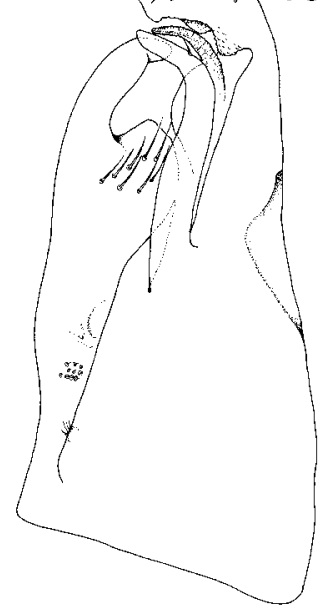

128
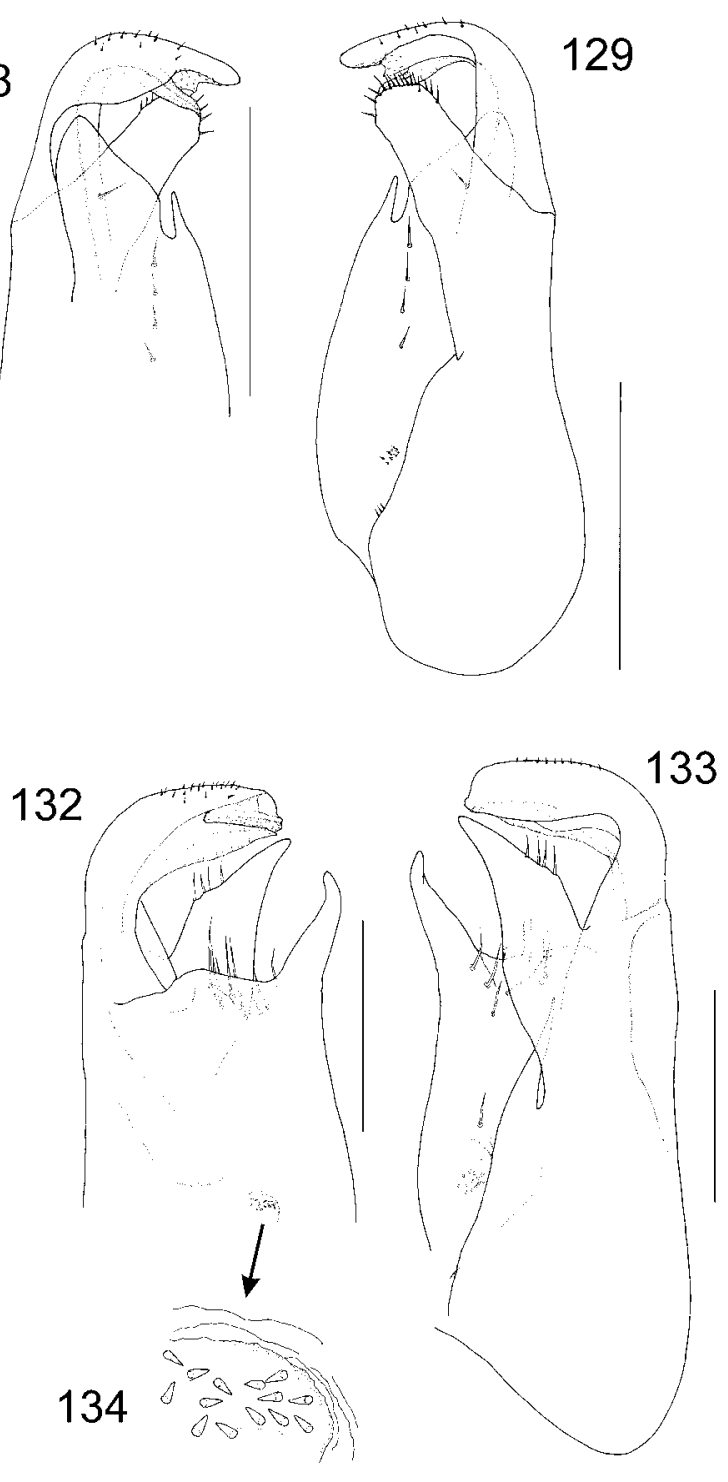
FIGURES 125-136. 125-127: Atelomastix psittacina, sp. nov., male holotype from Fitzgerald River National Park, Western Australia (WAM T73956), right anterior gonopod: 125: externolateral aspect; 126: internolateral aspect; 127 : detail of externolateral setae. Atelomastix rubricephala, sp. nov., male holotype from Waychinicup Nature Reserve, Western Australia (WAM T71606), right anterior gonopod: 128: externolateral aspect; 129: internolateral aspect. Atelomastix sarahae, sp. nov., male holotype from Cape Arid National Park, Western Australia (WAM T85863), right anterior gonopod: 130: externolateral aspect; 131: internolateral aspect. 132-134: Atelomastix tigrina, sp. nov., male holotype from The Cascades, Stirling Range National Park, Western Australia (WAM T74312), right anterior gonopod: 132: externolateral aspect; 133: internolateral aspect; 134: detail of externolateral setae. 135, 136: Atelomastix tumula, sp. nov., male holotype from Bluff Knoll Walking Trail, Stirling Range National Park, Western Australia (WAM T74317), right anterior gonopod: 135: externolateral aspect; 136: internolateral aspect. Scale lines $=0.5 \mathrm{~mm}$ (Figs. 125, 126, 128-133, 135, 136), 0.1 mm (Figs. 127, 134). 